\title{
A FIELD STUDY ON THE ECOLOGY OF CENTAURIUM VULGARE RAFN
}

\section{PROEFSCHRIFT}

TER VERKRIJGING VAN DE GRAAD VAN DOCTOR IN DE WISKUNDE EN NATUURWETENSCHAPPEN

AAN DE RIJKSUNIVERSITEIT TE UTRECHT, OP GEZAG VAN DE RECTOR MAGNIFICUS, PROF. DR. A. C. DE VOOYS, VOLGENS BESLUIT

VAN DE SENAAT IN HET OPENBAAR TE VERDEDIGEN OP MAANDAG 30 OCTOBER 1967 DES NAMIDDAGS TE 4.00 UUR PRECIES

DOOR

ARNOLDUS HENRICUS JOSEPH FREUSEN GEBOREN OP 25 APRIL 1934 TE BREDA

Drukkerij Uitgeverij H. Gianotten N.V. - Tilburg 
PROMOTOR: PROF. DR. J. LANJOUW 


\section{VOORWOORD}

Graag wil ik dank brengen aan personen en instellingen die het gereedkomen van dit proefschrift hebben mogelijk gemaakt.

In de eerste plaats dank ik mijn promotor, Prof. Dr. J. Lanjouw, door wie bij mij de belangstelling voor de plantenoecologie is gegroeid. De bewerking van twee doctoraal onderwerpen vond onder zijn leiding plaats. $\mathrm{Zijn}$ begeleiding tijdens de voorbereiding van dit proefschrift was van cardinaal belang.

Een belangrijk deel van mijn scholing in de Bijzondere Plantkunde heb ik te danken aan Prof. Dr. F. P. Jonker, die tevens voorgesteld heeft als studieobject „Centaurium vulgare” te kiezen. Van de overige hoogleraren en stafleden van de Rijksuniversiteit te Utrecht die een aandeel hadden in mijn algemene vorming als bioloog, wil ik graag met name noemen Prof. Dr. H. J. Vonk. Zijn onderwijs in de Chemische Dierfysiologie heeft een waardevol tegenwicht gevormd tegen mijn botanische specialisatie.

Bij de uitvoering van het veldwerk op Terschelling hebben drie instellingen een zeer grote rol gespeeld. Mijn onderzoek stond onder auspiciën van de Stichting Wetenschappelijk Duinonderzoek. Ik ben dankbaar dat haar bestuur een deel van het wetenschappelijk programma aan mij toevertrouwd heeft. De financiële middelen in de ruimste zin werden ter beschikking gesteld door de Nederlandse Organisatie voor Zuiver-Wetenschappelijk Onderzoek (Z.W.O. te 's-Gravenhage). Voor deze onmisbare steun heb ik de grootste waardering. Als basis voor het onderzoek diende het Biologisch Station "Schellingerland", waar werkruimte en tijdelijk ook woonruimte ter beschikking werden gesteld door het Rijksinstituut voor Veldbiologisch Onderzoek ten behoeve van het Natuurbehoud (R.I.V.O.N. te Zeist). Hiervoor betuig ik mijn dank aan het hoofd Prof. Dr. M. F. Mörzer Bruyns. Van de periode op Terschelling vermeld ik bovendien de bijzonder prettige assistentie verleend door B. Zwaagstra.

De uitwerking van het onderzoek volvoerde ik als staflid van het Instituut voor Oecologisch Onderzoek. Ik ben de directeur Dr. H. N. Kluyver (Arnhem) en het hoofd van de botanische afdeling te Oostvoorne, Dr. M. J. Adriani, zeer erkentelijk voor de vrijheid die ik daarbij genoten heb. Van mijn belangstellende collega's van "Weevers' Duin" noem ik graag Mejuffrouw J. H. M. Olk en Dr. P. Stoutjesdijk. Van de eerste ondervond ik belangrijke medewerking en de tweede heeft met grote bereidwilligheid het manuscript critisch gelezen.

Dr. K. U. Kramer (Utrecht) verstrekte adviezen op taxonomisch gebied. Drs. A. Touw (Leiden) controleerde de determinatie van enige mossen. 
M. M. Soekarjo-Korenhof corrigeerde op voortreffelijke wijze de engelse tekst. P. van der Kruk stelde enige verbeteringen voor betreffende deze tekst. De tekeningen werden drukklaar gemaakt door Th. Schipper. De inbreng van anderen wordt in de tekst genoemd.

Afgezien van bovengenoemde personen zijn er vele vegetatiekundigen die met hun eigen wetenschappelijke activiteit een onmisbare invloed hebben uitgeoefend op mijn onderzoek. De neerslag hiervan kan men aantreffen in dit proefschrift.

Met de allergrootste dankbaarheid vermeld ik dat mijn ouders en mijn vrouw een grote rol gespeeld hebben. Met verbeeldingskracht hebben mijn ouders de weg geopend naar de biologie. Van de bemoeienissen van mijn vrouw noem ik het liefst haar zorg mijn wetenschappelijke bezigheid in verhouding te brengen met andere facetten van het bestaan. 


\section{TABLE OF CONTENTS}

Samenvatting 9

The scope of the investigations and a summary of the results 13

Chapter 1: Introduction and the species Centaurium vulgare 17

1.1 The island of Terschelling and the localities investigated 17

$\begin{array}{ll}1.2 \text { Nomenclature } & 20\end{array}$

1.3 The life-cycle and the morphology of Centaurium vulgare 21

1.4 The varieties of Centaurium vulgare on Terschelling 24

1.5 The distribution of var. iberoides and var. latifolium in the
Netherlands

1.6 Experiments with var. vulgare and var. iberoides sown in different environments 26

1.7 Deviating populations of Centaurium vulgare 27

1.8 The chromosome number of Centaurium vulgare 28

1.9 The range of Centaurium vulgare and ssp. uliginosum 28

Chapter 2: The plant community of Centaurium vulgare

2.1 Methods of investigation and description 33

2.2 The history of the Centaurieto-Saginetum in the literature 35

2.3 Investigations on Terschelling 36

2.3.1 The typical Centaurieto-Saginetum 36

2.3.2 The subassociation of Sagina maritima 40

2.3.3 Centaurium vulgare in a secondary habitat 43

2.3.4 Vegetations with Centaurium latifolium 46

2.3.5 The presence of species in the Centaurieto-Saginetum 48

2.4 The distribution of plant communities with Centaurium vulgare 56

Chapter 3: The germination and the first stages of the life-cycle

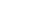

4

6

27
28

\section{3}

35
36
40
3
6
8
56

3.1 Introduction 59

3.2 The influence of the temperature $\quad 60$

3.3 The influence of the water factor $\quad 62$

3.3.1 Methods and general remarks $\quad 62$

3.3.2 The results of the experiments on field plots 64

3.3.3 Discussion of the results obtained on the field plots 65

3.4 Density of Centaurium vulgare in the second season 67 
Chapter 4: The relations between the water table and the Centaurieto-Saginetum

4.1 Introduction and method 69

4.2 Observations of the water table $\quad 69$

4.3 Conclusions and comparison with data from the literature 71

4.4 Centaurium vulgare in transect 1 72

4.5 Transect 2 and the composition of the Centaurieto-Saginetum 77

$\begin{array}{ll}4.6 \text { The capillary water in dune soils } & 79\end{array}$

$\begin{array}{ll}\text { 4.6.1 Some definitions } & 80\end{array}$

$\begin{array}{ll}\text { 4.6.2 The height of the capillary rise } & 81\end{array}$

4.6.3 The importance of the capillary water for Centaurium vulgare 82

4.7 Remarks on the fluctuating upper limit of the Centaurium-zone 82

Chapter 5: Centaurium vulgare and the soil moisture

5.1 Introduction and method 85

5.2 The soil moisture of the Centaurieto-Saginetum 85

5.2.1 Brief description of the slack sites $\quad 85$

5.2.2 Discussion of Table 12 and Fig. $9 \quad 86$

5.3 The soil moisture of the Boschplaat-sites $\quad 88$

5.3.1 Brief description of the sites $\quad 88$

$\begin{array}{ll}\text { 5.3.2 Discussion of Table } 13 \text { and Fig. } 10 & 89\end{array}$

5.4 The relations between the soil moisture and the population pattern of Centaurium vulgare $\quad 92$

Chapter 6: Centaurium vulgare and the salinity of the soil

6.1 Introduction 95

6.2 The chlorinity of the soil environment 96

$\begin{array}{ll}\text { 6.2.1 Method } & 96\end{array}$

6.2.2. Results of the analyses of the $\mathrm{Cl}^{\prime}$-concentration 97

$\begin{array}{lr}\text { 6.2.3 The halophyte Centaurium vulgare } & 100\end{array}$

$\begin{array}{ll}\text { 6.3 Centaurium vulgare and other saline soils } & 101\end{array}$

Chapter 7: Soil properties of the Centaurieto-Saginetum

7.2 Mechanical composition, adsorption complex and nitrogen 103

$\begin{array}{ll}7.3 \text { Algae and crust formation } & 104\end{array}$

$\begin{array}{ll}7.4 \text { Discussion of the tables with soil properties } & 105\end{array}$

Acknowledgements $\quad 113$

$\begin{array}{ll}\text { References } & 114\end{array}$ 


\section{SAMENVATTING}

In deze oecologische studie wordt een beschrijving en analyse gegeven van het milieu van de plantensoort Centaurium vulgare Rafn (Duizendguldenkruid). Voorzover mogelijk wordt aangetoond hoe de verspreiding en de wijze van voorkomen van deze plantensoort bepaald worden door de milieufactoren. Het onderzoek is gebaseerd op gegevens verzameld in het veld, vooral in de duinen en op de kwelders van het eiland Terschelling.

Centraal in het onderzoek stond het object Centaurium vulgare, waarvan verschillende facetten besproken worden zoals de nomenclatuur, de morphologie, de levensloop, de variabiliteit en het areaal. De volgende belangrijke punten uit deze bespreking kunnen genoemd worden: De levenscyclus van Centaurium vulgare duurt twee jaren. Naast de rechtopstaande typische planten komen in Nederland twee andere vormen voor, die opnieuw beschreven worden als: var. iberoides (Jonker) Freijsen stat.nov. en var. latifolium (Marsson) Freijsen nov.comb. De eerste variëteit wordt gekenmerkt door een liggende-opstijgende habitus, de tweede door bredere (rozet-)bladeren. Enige verschilpunten in de oecologie van de onderscheiden vormen van Centaurium vulgare worden behandeld. Het areaal van Centaurium vulgare valt uiteen in twee gedeelten. Allereerst komt de soort voor langs de kusten van NW. Europa en verder verspreid in continentaal Europa.

Het plantengezelschap van Centaurium vulgare staat bekend als de ass. Centaurieto-Saginetum moniliformis D., S. et W. 1940. Het bleek nodig te zijn deze associatie een nieuwe samenstelling te geven. In principe is het gezelschap steeds opgebouwd uit drie groepen van plantensoorten nl. enkele karakteristieke constante soorten die optimaal ontwikkeld zijn binnen vegetaties van het gezelschap bijv. Centaurium vulgare, een groep van droogteminnende soorten die gewoonlijk hoger en droger voorkomen en tenslotte een groep van vochtminnende (soms ook zoutminnende) planten waarvoor het tegendeel geldt. Anders gezegd, vegetaties van Centaurium vulgare komen steeds voor in het overgangsgebied van droge duintop naar natte duinvallei of in soortgelijke situaties. Een van de gevolgen hiervan is, dat de associatie moeilijk te classificeren is in de bestaande hogere eenheden van het systeem van plantengezelschappen. Afgezien van het gezelschap in zijn typische constellatie wordt een ,zoute" subassociatie: subass. van Sagina maritima Freijsen subass.nov. op kwelders aangetroffen. Tenslotte, een onderscheiding van droge en natte varianten binnen het plantengezelschap is mogelijk.

Over de eerste levensphasen van de plant werden waarnemingen en tellingen uitgevoerd op veldjes van beperkte omvang. Ofschoon het zaad van 
Centaurium vulgare reeds in september rijp is en verspreid wordt, vindt de kieming eerst in de daarop volgende lente plaats. Ontkieming van het zaad treedt pas op wanneer de temperatuur bepaalde niveaus bereikt heeft, zoals die in mei buiten voorkomen. Belangrijk bij de kieming zijn de vochtomstandigheden van het milieu. Het vochtgehalte van de bodem bepaalt, waar ontkieming mogelijk is, hoeveel zaden per eenheid van oppervlak zullen ontkiemen en hoelang ontkieming mogelijk is.

Het grondwater speelt een overheersende rol in het milieu van Centaurium vulgare. De plant komt slechts voor op plaatsen met een hoge grondwaterstand: maximale zomerdiepte $100 \mathrm{~cm}$ en maximale diepte tijdens ontkieming $55 \mathrm{~cm}$. Dit laatste hangt samen met de capillaire opstijging van het grondwater in duinbodems, die hoger bleek te zijn dan meestal verondersteld wordt in de literatuur $(\max .55 \mathrm{~cm})$. Slechts daar vindt ontkieming plaats, waar de oppervlakte tijdens de kieming bevochtigd wordt door opstijgend capillair water. Tengevolge van de invloed van de diepte van het grondwater en van het bodemvocht enerzijds op de dichtheid van de ontkiemende zaden anderzijds kan men uiteindelijk in populaties van volwassen planten van Centaurium vulgare op duinhellingen steeds een zonale opbouw onderscheiden. Bovenaan een subzone van wijduiteenstaande grote planten, in het midden een dichte begroeiing van kleinere planten en onderaan een subzone van kleine verspreide exemplaren. Een verder gevolg van de rol van het grondwater is, dat jaarlijkse schommelingen in de grondwaterstand tot uiting komen in schommelingen in de hoogte van de bovengrens van de zone van Centaurium vulgare en in wisselingen in de samenstelling van de vegetaties.

Voor een nader inzicht in de vochtomstandigheden werd gedurende een geheel seizoen op een aantal uiteenlopende standplaatsen van Centaurium vulgare in de allerbovenste bodemlaag van $0-1 \mathrm{~cm}$ en in de daarop aansluitende laag van $1-20 \mathrm{~cm}$ het watergehalte bepaald. In het typische bodemmilieu van Centaurium vulgare kan direct na de kiemtijd, nl. in de tweede helft van mei sterke oppervlakkige uitdroging plaats vinden. Elke onderscheiden standplaats van Centaurium vulgare bezit een eigen vochtniveau en wordt gekenmerkt door specifieke wisselingen van het vochtgehalte van de bodem. Op lagere niveaus in het duinlandschap is een overmaat aan water beperkend voor het voorkomen van Centaurium vulgare.

In het bodemvocht uit het milieu van Centaurium vulgare is steeds een (geringe) hoeveelheid zout ( $\mathrm{NaC1}$ ) anwezig, waardoor men per definitie dit bodemwater als brak en Centaurium vulgare als zoutplant moet beschouwen. Deze voorkeur van Centaurium vulgare voor zoute bodems blijkt ook uit het areaal dat immers bestaat uit een verspreidingsgebied langs de zeekusten en uit zoutgebieden in het binnenland.

Een aantal andere bodemfactoren in het milieu van Centaurium vulgare zijn geanalyseerd. Ofschoon de plant als een pionier van jonge zandige duinbodems beschouwd wordt, treedt zij eerst op, nadat de bodemoppervlakte 
enigszins is vastgelegd door wieren. Deze bodems bevatten altijd enige vrije koolzure kalk en zijn daardoor neutraal tot alkalisch. Zij zijn daarnaast bijzonder arm aan voedingselementen. 


\section{THE SCOPE OF THE INVESTIGATIONS AND A SUMMARY OF THE RESULTS}

The field study on the ecology of the species Centaurium vulgare Rafn described in this publication consisted of three parts:

1. the investigation of the occurrence, development and distribution pattern of the species under various natural conditions,

2. the analysis of environmental factors prevailing in different habitats and 3. the explanation of the relations between the behaviour of Centaurium vulgare and its environment.

Natural populations of Centaurium vulgare in dune slacks and on salt marshes of the island of Terschelling (Netherlands) were the main objects of this study. The approach was threefold. A great part of the investigations was purely descriptive. The knowledge of the soil environment i.e. the chemical factors was based on laboratory analyses. In some cases simple field experiments were carried out.

In this way satisfactory explanations of some aspects of the ecology of Centaurium vulgare were obtained. However, these explanations are only provisional, because the results of this study form new problems. These problems cannot be solved by means of the methods used in this field study; for that experiments and eco-physiological methods seem to be necessary. There is also a quite different way to extend the knowledge of the ecology of Centaurium vulgare. That is a study of the variability of the species in different regions throughout its range. Such a phytogeographical study would be a fair complement to the more detailed investigations of this publication, which mainly deal with the occurrence of Centaurium vulgare in a small part of its range.

The investigations were facilitated by some properties of the plant Centaurium vulgare and its habitat. The plant is characterized by a rather short life-cycle, great numbers of specimens and a small well-delimited size. The environment is a suitable object for analysis as a consequence of the simple structure of vegetation and soil. These characteristics of plant and environment typify the pioneer habitat, which is usually regarded as propitious for ecological research.

The main results of this study can be summarized as follows:

1. the plant: Most specimens of Centaurium vulgare germinate in April and May. They remain in rosette-form during the first summer and the following winter. During the second summer stems, flowers and seeds are formed successively. Centaurium vulgare is a true biennial. Apart from the typical erect plants of Centaurium vulgare two divergent paramorphs occur in the 
Netherlands. These are typified viz. by a procumbent-ascending habit and broader (radical) leaves. Both these paramorphs are described again as: var. iberoides (Jonker) Freijsen stat.nov. and var. latifolium (Marsson) Freijsen nov. comb. Differences in ecology and distribution between the three paramorphs of Centaurium vulgare are treated. The map of the distribution range of Centaurium vulgare - including the continental subspecies uliginosum was based on the literature. Some older papers do not mention the occurrence of Centaurium vulgare in Russia.

2. the plant community: Contrary to previous descriptions of the plant community of Centaurium vulgare: the association Centaurieto-Saginetum moniliformis D., S. et W. 1940, a new composition and subdivision of the community is given. Both the typical subassociation and the saline subassociation of Sagina maritima Freijsen nov. subass. can be divided into a dry and a wet variant. The original classification in the Nanocyperion-alliance is rejected. Because vegetations of Centaurium vulgare were always found in the transition zone between communities of xerosere and hygrosere (or halosere), their classification in one of these formations is impossible. The similarity between the associations Centaurieto-Saginetum moniliformis and Sagineto maritimae-Cochlearietum danicae is discussed.

3. the germination: The germination and the growth and density of juvenile plants were observed on field plots. The temperature conditions determine the time of germination. The moisture conditions of the soil determine where seeds germinate and how many, as well as the length of the germination period.

4. the ground water: Germination can only occur on a level that is reached by the uprising capillary water. The capillary rise in dune sand can amount to $55 \mathrm{~cm}$. The zone of Centaurium vulgare on dune slopes can be divided into three subzones, each characterized by a certain density and plant size in dependence on the soil water table. Annual fluctuations of the phreatic level coincide with equal fluctuations of the Centaurium-zone. Differences in the composition of the plant community of Centaurium vulgare result from these fluctuations.

5. the soil moisture: The subzones of the Centaurium-populations and the distinct forms of the Centaurieto-Saginetum are typified by particular soil moisture levels and fluctuations. The uppermost soil layer in the typical habitat of Centaurium vulgare may become strongly desiccated. However, the water supply in the root zone is permanently above the wilting coefficient. The lower limit of the Centaurium-belt is determined by the increasing water content.

6. the chlorinity: In the soil solution of the Centaurium-sites investigated $\mathrm{Cl}$-ion concentrations from 0,30 to $0,03 \%$ were measured. Centaurium vulgare is oligohalobious. Outside the coastal region of NW. Europe Centaurium vulgare occurs on saline soils of different nature. 
7. other soil factors: The soil surface is always more or less fixed, especially because of the occurrence of algae. The soil has a (low) content of free carbonate and it is of alkaline reaction. Centaurium vulgare is calcicolous. The soil environment of Centaurium vulgare is poor in nutrients like many other young dune soils. 
Chapter 1:

\section{INTRODUCTION AND THE SPECIES CENTAURIUM VULGARE}

\subsection{The island of Terschelling and the localities investigated}

The island of Terschelling is one of the Westfrisian Islands situated in the north of the Netherlands. These islands form the greatest part of the phytogeographic "Wadden-District", the soil of which is characterized by a very low content of calcium carbonate $\left(\mathrm{CaCO}_{3}\right)$. Especially Terschelling is very poor in chalk. Many calcifugal communities occur on the island. The extensive secondary dune slacks are covered with heath communities and the climax community on southern exposures in the duneland is the VioletoCorynephoretum. According to WESTHOFF (1947 b) also the $\mathrm{Fe}_{2} \mathrm{O}_{3}$-content in the sand of the coastal ridge is very low, namely $0,24 \%$. This is an important cause of the great mobility of the dune sand. In the past - when cattle used to graze in the dunes - large parts of them moved and were rejuvenated.

The island is about $30 \times 4 \mathrm{~km}^{2}$ and it is orientated from SW. to NE., i.e. in the direction of the prevailing wind. On the SW.-point of the island sand flats periodically join the main island. The last one was the "Noordvaarder", which dates from about 1866. This extensive sand flat supplies enormous quantities of sand for the building-up of dunes, especially in the adjacent part of the island.

Terschelling is characterized by an eu-atlantic climate. May is the driest month (WESTHOFF 1947b).

For a better understanding of the investigations described in the next chapters more details on the localities of this study will be mentioned. A great part of this study was carried out on the "Boschplaat". See Fig. 1. The Boschplaat is a sandy salt marsh with a length of $9 \mathrm{~km}$, which forms the eastern point of the island. Originally it was a sand flat almost without vegetation. In the period 1931-1938 (VISSER 1947) a sand dike was constructed with the help of wind and sand movement in the highest and most sandy northern part of the sand flat. This sand dike stretches from west to east and prevents the entrance of the North Sea-water. Only from the south the Boschplaat-area can be inundated by sea-water. After the formation of the sand dike a rapid development took place on the Boschplaat. During inundations silt was deposited and halophytic plants gradually established themselves. This process was described by Westhoff (1947 b). Nowadays the Wadden Sea-water reaches the salt marsh through some creeks lying between a number of dune groups called: "Eerste Duintjes", "Tweede Duin- 
Fig. 1: map of the island of Terschelling

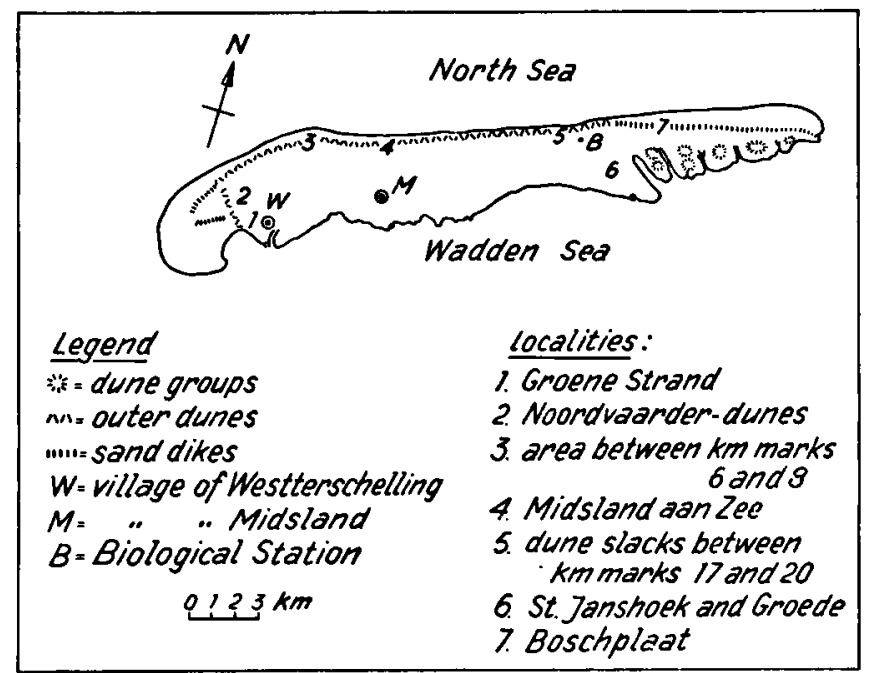

tjes", etc. ('First Little Dunes", "Second Little Dunes", etc.). For more details on these dune groups the reader is referred to DE Fouw (1962-1963).

Many of the sites investigated were situated on so-called "horseshoe dunes". These small dunes have a diameter of about $40 \mathrm{~m}$ and a height of about $2 \mathrm{~m}$. Quite a number of these small dunes lie between the sand dike in the north and the Eerste Duintjes and the Tweede Duintjes in the south. They originate from the embryonic dunes present on the Boschplaat in the period of the formation of the sand dike. They are typified by a horseshoe form with the convex side westward. Halfway this convex slope a bare zone occurs also forming a horseshoe, when seen from above. This bare zone - just below the storm flood-mark - develops by erosion during storm floods in autumn. The water propelled by the western gales erodes the surface material, which is deposited on the eastern sides of the dunes afterwards from which process the two "horns" of the horseshoe originate. The bare zones of the horseshoe dunes and other open spots on hummocks on the flat are ideal environments for the communities of Centaurium vulgare and Sagina maritima.

The southwestern part of the Boschplaat is different in two respects. It is much older and it used to be grazed by young cattle. $A$ greater number of glycophytes occurs on this part of the Boschplaat, which is called "Groede". A small part of this region called "St. Janshoek" was of interest in the present investigations in view of the occurrence of a remarkable variety of Centaurium vulgare: var. latifolium. The occurrence of this paramorph here seems to depend on the age of vegetation and environment. 
Just east of the sand flat Noordvaarder there is a dune area with the same name, consisting of a complex of low ridges and slacks. Fine stands of Centaurium vulgare occur on the slopes. The variety iberoides is found here especially. This area has recently developed; it is not mentioned by VAN DIEREN (1934). As a consequence of the small height of these dune ridges and a high water table Ammophila arenaria plays a minor part. There is a rapid succession of the following constituents of the xerosere: vital Elytrigia juncea, dead specimens of the same species and Corynephorus canescens. Although the outer ridge is formed by fresh sand of the sand flat the Noordvaarder, it only contains $0,1 \%$ free carbonate. This is the reason, why here and elsewhere on Terschelling calcifugal species must occur in early stages of the succession.

Between the $\mathrm{km}$ coast-marks 6 and 8 a region of almost natural yellow dunes is found in the following zonation: embryonic dunes with Ammophila arenaria and Ammocalamagrostis baltica, a long rather narrow valley with Hippophaë rhamnoides, a zone consisting of small secondary dune slacks and small Ammophila-dunes with steep slopes as a consequence of wind erosion. On the landward side this area is bordered by a partly artificial sand dike. WeSTHOFF (1947 b) called this region "El Dorado". In the present study the area was of interest because of the occurrence of Centaurium vulgare in the secondary dune slacks. It is designated as area " $\mathrm{km}$ marks 6-8".

On the west side of the village of West-Terschelling and bordered by the Noordvaarder-dunes in the north there is a remarkable area called "Groene Strand" ("Green Beach"). It is a small salt marsh only inundated by storm floods from the Wadden Sea. It is a very old part of the island, which was and is disturbed in many ways e.g. by sod cutting, grazing, picknicking etc. Apart from a number of common plants the rare species Cicendia filiformis and Centaurium vulgare var. latifolium are found here, as well as the very rare species Scirpus americanus (WESTHOFF and MöRZER BRUYNS 1956).

Almost everywhere the outer dune ridge of Terschelling has been reinforced e.g. by planting Marram-tussocks, or influenced in one way or another. Grey dunes and heath lie behind it. However, in some places the environment of Centaurium vulgare has been formed secondarily. Three varieties of Centaurium vulgare can be found in places where sods were cut in the sea resort of Midsland-aan-Zee. A part of this study was carried out in little artificial dune slacks between $\mathrm{km}$ marks 17 and 20 , which dune slacks were dug out when a secondary sea-defense wall was constructed.

Most of the investigations were carried out in the localities of Terschelling just described. In the period 1961-1964 the author stayed at the Biological Field Station there. From this base excursions were made, also in other dune regions in the Netherlands especially on the Westfrisian Islands. In 1965 the study was continued at the Biological Field Station on the island of 
Voorne. In this year data on the germination of Centaurium vulgare were obtained. On Voorne Centaurium vulgare occurs chiefly in a rather small primary dune valley and on a small brackish salt marsh.

\subsection{Nomenclature}

The correct name for the plant species treated in this study is Centaurium vulgare Rafn (1800). The Dutch name is: Strandduizendguldenkruid (English: Dune Centaury). The problem of the nomenclature of this Centauriumspecies was solved by STERNER (1939), who discussed the original description of the Danish botanist C. G. Rafn in: Danmarks og Olsteens Flora, 1800. Sterner disputed the correctness of the epithet "vulgare", and he rejected the epithet "littorale" used in the British literature. According to Sterner the description of Rafn was vague and could become a reason for misunderstanding. In his taxonomic study of the Dutch Centaurium-species JoNKER (1950) followed Sterner. Furthermore, the name Centaurium vulgare is used by most European botanists e.g. in the following nomenclatural surveys: Hylander (1945) - Scandinavia, Mansfeld (1939) - Germany, JaNCHeN (1958) - Austria.

The opposite point-of-view in the discussion on the nomenclature of the Dune Centaury was maintained by Gilmour (1937). According to this author the description given by Rafn and the figure mentioned by him referred to another species, the species nowadays called Centaurium minus Moench and not to Centaurium vulgare. In that case the oldest description was given bij Turner in 1805 who called the species: Chironia littoralis. So the recent name should be - at least in the opinion of Gilmour - Centaurium littorale (Turner) Gilmour. This name can be found in the floras of CLAPHAM et al. (1962) and HeuKels-Van Ooststroom (1962).

Two varieties of Centaurium vulgare found on Terschelling will be treated more extensively below. In order to distinguish the typical paramorph from these varieties, it is called var. vulgare in some places of this publication. In continental Europe a hairy subspecies of Centaurium vulgare occurs with the name: uliginosum (W.K.) Soo (1941). This name was used for instance by JANCHEN (1958) and WENDELBERGER (1950).

As to the nomenclature of other species mentioned in this study the author followed:

HeUKels-Van Ooststroom (1962) ....... for vascular plants

VAN Der WiJK (1962)............. for mosses and liverworts

Hillmann and Grummann (1957) ...... for lichens.

The following infraspecific taxa, not mentioned by Heukels-van Ooststroom, were distinguished:

Agrostis stolonifera L. var. arenaria J. et W. (1940); see JANSEN (1951)

Agrostis stolonifera L. var. salina J. et W. (1940); idem 
Festuca rubra L. ssp. arenaria (Osbeck) Richter; see RoTHMALER (1963)

Festuca rubra L. ssp. litoralis (Hackel) Rothm.; idem

Sagina nodosa (L.) Fenzl var. moniliformis G. F. W. Meyer (1924); see BuCHENAU (1896).

With respect to the above mentioned infraspecific taxa the following remarks can be made. Both paramorphs of Agrostis stolonifera are closely related. On the salt marsh the Boschplaat they occur together. According to WESTHOFF (1964, pers. comm.) they form an ecocline on the gradient saltfresh. Also the Festuca-forms grow near each other. Festuca rubra ssp. arenaria is a common plant on dry dunes. In a previous paper (FrEIJSEN and VAN HeusDeN 1965) it was mentioned already that this grass is most important in the yellow dunes of Terschelling, whereas the species Festuca juncifolia St. Amans was not found. Ssp. litoralis, an important halophyte, is treated as a forma in the papers of BEEFTINK (1965 and 1959) on salt marsh communities. This paramorph - which is characterized by a typical habit, slender and glabrous spikelets and a different chromosome number (DUYvEndaK 1963, pers. comm.) - can well be regarded as a subspecies.

In the literature the coastal form of Sagina nodosa was called var. moniliformis. This coastal paramorph is characterized by small roundish densely leaved buds in the axils of the stem leaves, giving the plant a knotlike appearance. After the vegetation period the buds get detached. Floating on the water surface of the inundated dune slack they are dispersed by the wind and eventually deposited in flood-marks, where they form roots and get established as juvenile plants. The seeds, however, sink and die in the water. In this way the axillary buds are an important adaptation of var. moniliformis (ELLISTON WRIGHT 1951-1953). In a preliminary study on Dutch herbarium plants of Sagina nodosa the same buds appeared to occur on inland plants, but in most cases they were less numerous and inconspicuous. It is doubtful whether the characteristic of the axillary buds is sufficiently important to distinguish the variety moniliformis as such. For the time being we have followed the literature.

As to the nomenclature of syntaxa the author used the current names as these are found in the publications of Westhoff (1947 b) and BeEfTINK (1965).

\subsection{The life-cycle and the morphology of Centaurium vulgare}

In this section a description of the morphology and life-cycle of Centaurium vulgare will be given. The typical paramorph Centaurium vulgare var. vulgare found and investigated by the author on Terschelling particularly on the Boschplaat is described. Emphasis will be laid on those properties which distinguish it from other varieties. For more complete descriptions of the genus Centaurium Hill the reader is referred to the relevant papers.

Under normal circumstances Centaurium vulgare is a biennial plant. Most 
specimens germinate in spring; only a small part of the populations investigated germinated in summer. (According to ClaphaM et al. (1962) Centaurium littorale $=$ vulgare is an annual germinating in autumn.) The roots of the seedlings grow rapidly so that soon they pass through the upper soil layer, which may become unfavourable through desiccation. In the beginning the growth of the overground part of the plant i.e. the rosette is retarded, due to the rapid extension of the root system. During the first season a rosette is formed consisting of a number of spathulate obtuse leaves with a length of about $26 \mathrm{~mm}$. The length/width ratio is 5,5. The occurrence of the rosette is a significant difference with a second Dutch Centaurium-species namely Centaurium pulchellum (Sw.) Druce, an annual without rosette. Centaurium vulgare var. latifolium differs from Centaurium vulgare var. vulgare by broader leaves.

In the spring of the second season the stems begin to develop. Vital specimens of Centaurium vulgare possess one or more erect stems. The maximal length is $25 \mathrm{~cm}$ and the highest number of stems observed during the investigations amounted to 41 . (The variety iberoides is marked by procumbent-ascending stems.) The stems may be branched in the upper part and sometimes even lower e.g. from the third internode upward. The branches are erect and the angle between stem and branch is always sharp.

In marginal environments e.g. the wet lower border of the Centauriumzone and on pastured salt marshes small specimens of Centaurium vulgare occur. These plants have only one stem a few centimetres long and one or a few often quadrimerous flowers. They are clear modification forms without any taxonomic value. Earlier they were described as forma pumilum JoNKER (1950) and forma uniflorum (Schmidt) RoBIJNs (1954).

The cauline leaves are linear-lanceolate with less obtuse tops. The same (homotypic) lowest cauline leaves of fifty plants were measured. The following average values were measured: length $21,5 \mathrm{~mm}$, width $4,4 \mathrm{~mm}$, and ratio 4,9. Cauline and radical leaves possess a main nerve and two indistinctly secondary nerves. In the middle part of the stem the internodes are longer than the corresponding leaves. STERNER (1940-1941) mentioned this feature to distinguish the section $e u$-vulgaria within the species Centaurium vulgare.

Centaurium vulgare has a dichasial inflorescence. In the beginning the inflorescence is densely corymbiform, because the flowers are almost at the same level, but later the branches of the inflorescence elongate. In the fruitbearing plant the old inflorescence is very open and all flowers or fruits are zlearly separated by the ramifications of the peduncle. The angle between the ramifications of the inflorescence and the vertical varies between 10 and 25 degrees. The primary and secondary flowers are always sessile. The distance between the bracts and the calix does not exceed $1 \mathrm{~mm}$. It is important to emphasize these facts, because the structure of the inflorescence 
plays a great part in descriptions of Centaurium-taxa of many authors:

1. In Centaurium minus Moench the flowers are always at about the same level in corymbous inflorescences (HEGI 1927).

2. The infraspecific categories: var. gotlandicum Wittr. and var. subprocumbens Wittr. created as such by Wittrock in 1884 and adopted by STERNER (1940-1941) were characterized by elongated pedicels.

3. According to most descriptions Centaurium vulgare possesses sessile flowers e.g. Sterner (1940-1941) - var. genuinum Wittr.; ClaPhaM et al. (1962). However, according to FouRnIER (1961) Centaurium compressum $(=$ vulgare $)$ has pedunculated flowers.

Several authors have drawn the attention to the fact that the calix has the same length as the tube of the corolla at anthesis. Later on the growing fruit becomes longer than the calix, obtaining a length of about $12 \mathrm{~mm}$. For the proportions and structure of the flowers the reader is referred to good descriptions and sketches in: Hegr (1927), HeUKels-VAN OOSTSTROOM (1962) and JONKER (1950). Generally the colour of the flowers is called pink. More precisely this colour may be called roseïne-purple (no. 629/1 in the Horticultural Colour Chart $(1939,1941))$. In the sections 1.7 and 1.4 it will be shown that some populations of Centaurium vulgare and also the var. latifolium deviate in this respect. For three years on the same spot near the Biological Station on Terschelling specimens of a white-flowered form were observed. This (genetic) paramorph was only found in a few other places. It is very rare and perhaps this is the reason why it has not been mentioned by JONKER (1950) and ROBIJNS (1954). In the past it was reported for the Eastfrisian Islands by BuchENAU (1896) and NöldEKE $(1872,1873)$.

In the first stages all parts of the plants are green. During the second summer i.e. the flowering time, the plants turn yellow, starting in the lower parts. At the same time or earlier the rosette leaves disappear. Therefore, a normal adult plant never has a fully developed rosette. The same is true for herbarium plants as these are usually collected in the flowering stage. The biennial Centaurium minus shows the same phenomenon. For comparison of herbarium specimens of Centaurium-taxa the rosette as a morphological feature can hardly be used (see also JoNKER 1950). Sometimes flowering plants are found in autumn. It was observed by the author that many of these plants were grazed and formed stems for the second time. These misformed plants keep their rosettes much longer and also the discoloration is retarded. This phenomenon is rather common, probably because Centaurium vulgare occurs often in places grazed by cattle or rabbits. In the present author's opinion many plants of the paramorph described by JONKER (1950) as f. rosulatum - this idea was adopted by RoBIJNS (1954) for Belgium - should be considered as a modification originated in the way just mentioned.

Finally, it may be said that Centaurium vulgare is somewhat succulent 
and glabrous. According to several authors scaberulous forms occur in Great-Britain. More clearly scaberulous is the continental European subspecies uliginosum. The British paramorphs were described by CLAPHAM et al. (1962) and O'CONNOR (1955).

\subsection{The varieties of Centaurium vulgare on Terschelling}

Apart from the typical paramorph Centaurium vulgare var. vulgare, described in section 1.3, two other varieties occurring on Terschelling were studied. In the following descriptions of these varieties their differences from var. vulgare will be stressed.

var. iberoides (Jonker 1950) Freijsen stat. nov.

Basionym: Centaurium vulgare Rafn forma iberoides Jonker, Ned. Kruidk. Arch. (1950). 57: 169-198.

Type: herbarium of the Royal Botanical Society of the Netherlands in the "Rijksherbarium" at Leyden.

Amended description: stem or stems at the base procumbent, upper parts as well as branches ascending; small plants with only one (unbranched) stem may be erect, but they always possess a flexuose basal part (a S-bend); the angles between the branches of the inflorescence and the main axis are sometimes wide ( 50 degrees of more); the basal leaves are smaller: length $21,3 \mathrm{~mm}$, width $4,9 \mathrm{~mm}$ and ratio 4,4 (average numbers of 250 plants of the Noordvaarder).

On the basis of the similarity in habit the plants of Terschelling and the herbarium-specimens studied and recorded by JONKER (1950) are regarded by the present author as being identical. However, in his opinion the description of the inflorescence given by Jonker is not correct. The features mentioned by Jonker: "Flores in inflorescentiis subcapitatis multibracteatis dispositae" can only be observed in the case of plants with very young and not full-grown inflorescences. Such dense inflorescences are also found in the other varieties of Centaurium vulgare. These features have no taxonomic value. Furthermore, as appears from the amended description specimens of var. iberoides sometimes seem to possess a more lax inflorescence than the var. vulgare.

The paramorph iberoides is sufficiently defined to be regarded as a variety. But for the very small individuals and plants of shaded sites the paramorph can easily be recognized as such. It is a genetically stable type maintaining its characteristic form when cultivated after having been sown in a greenhouse, and afterwards in the experimental garden. A distinctive characteristic is its distribution.

In the literature another procumbent form of Centaurium vulgare has been described. WITTROCK (1884) described the variety subprocumbens typified by its procumbent growth habit and pedunculated flowers. On the 
one hand there is a great similarity between iberoides and subprocumbens namely with respect to the habit, on the other hand the inflorescences seem to vary in an important feature. The author never observed really pedunculated flowers in the Dutch material. The variety subprocumbens Wittr. was recorded by Hegr (1927) - in the then called Eastern Prussia, Melderis (1931) - Palanga (Lithuania) and Ziemupe (Latvia) and Sterner (1940-1941) - Gotland (Sweden).

In the southwestern part of the range of Centaurium vulgare procumbent forms of the species do not occur. This conclusion was drawn from descriptions and data given by o.a. Clapham et al. (1962) for Great-Britain, ROBIJNS (1954) for Belgium and BoNNIER (1912-1934) and FouRNIER (1961) for France.

var. latifolium Marsson (1869) Freijsen nov. comb.

Its leaves - particularly the basal leaves - are broad. The average values of 250 basal leaves of as many plants were: length $20,2 \mathrm{~mm}$, width $6,3 \mathrm{~mm}$ and ratio 3,2 . At the same time these leaves were not as thick and succulent as those of var. vulgare. They possessed not as many cell layers. The nerves were slightly more distinct. As for the leaves var. latifolium is intermediate between Centaurium vulgare vulgare and Centaurium minus as was already stated by the original author MARSson (1869). Habit and inflorescence of the variety latifolium is lax as a consequence of elongated internodes and branches of the inflorescence. The plants on Terschelling belonging to this variety were characterized by a blue-green colour and flowers with a very light tone of roseine-purple, approaching the white colour: no. 629/3 in Hort. Col. Chart. The deviating colours of the plants themselves and their flowers are not mentioned by Marsson. The present author does not know if these properties are found in the var. latifolium outside Terschelling.

Marsson found this variety of Centaurium vulgare in the dunes of Usedom in Northern-Germany. In the "Prodromus" (VUYCK 1904) the find of a specimen of latifolium by Holkema on the Westfrisian island of Schiermonnikoog was reported. Also Hegi (1927) and SterNer (1940-1941) mentioned the variety. JONKER (1950), who based his conclusions on a study of a very great part of the Dutch herbarium specimens of Centaurium vulgare, attached no value to the var. latifolium. In 1966 there was in the collection of the "Rijksherbarium" at Leyden only one clearly distinguishable specimen of latifolium. As was already mentioned in the preceding section, adult plants collected for herbarium purposes will often have lost their rosette-leaves. The difference between latifolium and vulgare with respect to the breadth of the cauline leaves is not so great in dried plants as to enable us to make a distinction. It will be clear that also the deviating colours of the plants cannot serve as characteristics in herbarium specimens.

Plants of Centaurium latifolium and iberoides were grown from seeds 
under artificial circumstances. They appeared to be genetically fixed. Dried specimens of these cultivated plants were deposited in the herbarium of the Biological Station at Oostvoorne.

\subsection{The distribution of var. iberoides and var. latifolium in the Netherlands}

About the distribution of the varieties iberoides and latifolium in the Netherlands the following can be said. During the investigations the var. iberoides was observed on all Westfrisian Islands except Texel and furthermore on the islands of Schouwen, Goeree, Rozenburg (Vogelplaat) and Voorne in the SW.-part of the Netherlands. In these last two localities iberoides is the only paramorph of Centaurium vulgare. In the past var. iberoides was found on the mainland coast in the provinces N.- and S.-Holland and on the islands of Texel and Walcheren. Herbarium specimens from these places are present in the herbaria of Leyden and Utrecht. Moreover, JONKER (1950) mentioned herbarium specimens collected in these regions. Var. latifolium is very rare. The present author observed it only on the island of Terschelling. The collections of Leyden and Utrecht do not contain distinguishable specimens from other places.

Below, the distribution of the two varieties on the island of Terschelling is treated in detail. Var. iberoides occurred in the following dune areas: in the Noordvaarder-dunes and on some isolated spots along the north coast of the island, namely in a small slack near $\mathrm{km}$ coast-mark 6, in Midslandaan-Zee (with var. vulgare and latifolium) and a few plants were found near $\mathrm{km}$ coast-mark 20 in the NW.-corner of the Boschplaat. Var. latifolium was found on the Groene Strand, in Midsland-aan-Zee and on the St. Janshoek. In 1962 some plants possibly belonging to var. latifolium were observed in the neighbourhood of the Biological Station. In the distribution pattern of var. latifolium there is one remarkable feature. The two main areas: Groene Strand and St. Janshoek are of very old age. Both areas are covered with a grazed vegetation characteristic for the transition between halosere and hygrosere. According to WeSTHOFF (1966, pers. comm.) these ecotone environments were already present centuries ago. Some properties of these environments can also be found in the habitat in Midsland-aan-Zee. In view of these facts the author supposes that the particular distribution pattern of Centaurium latifolium is determined by a different ecology of the paramorph.

\subsection{Experiments with var. vulgare and var. iberoides sown in different environments}

With respect to the distribution of the varieties vulgare and iberoides of Centaurium vulgare in the Netherlands it is possible to distinguish dune regions with vulgare: Boschplaat, with iberoides: Voorne, and with both 
varieties: Noordvaarder and "Oosterstrand" on Schiermonnikoog. When we compare for instance Voorne with the Boschplaat the conclusion might be drawn that both varieties differ in some ecological respects. In the Noordvaarder-dunes they form in many places a mosaic pattern consisting of specimens of only one variety. This phenomenon seems to show a difference in micro-ecological respect. DE BRUYN and BORRIAS (1964) did not succeed in finding such a difference, neither in the vegetation nor in the abiotic environment.

To gain more information on this problem some experiments were carried out:

1. seed of var. vulgare (Boschplaat) was sown on the Noordvaarder,

2. seed of var. iberoides (Noordvaarder) was sown on the Boschplaat,

3. seed of var. vulgare (Boschplaat) was sown on Voorne,

4. seed of both varieties was sown in the experimental garden.

In the experiments 2 and 3 seed was sown in the undisturbed environment of Centaurium, as well as on bare plots which had been dug up before.

In experiment 1 normal germination and establisment took place as could be expected on the basis of the occurrence of var. vulgare on the Noordvaarder. Concerning experiment 2, germination and establishment of iberoides took place on the field plots - perhaps the number of plants was somewhat lower than that of var. vulgare which was sown too - , but germination in the natural vegetation was apparently very low. On five sites only one specimen of iberoides was found after two years. On Voorne var. vulgare established itself on prepared field plots as well as in the natural vegetation of two primary dune valleys. The seeds of var. vulgare sown on a plot in the experimental garden germinated. The adult plants originated from this seed bore fruit and a second generation of seedlings established itself on the same plot. The author did not succeed in obtaining seedlings of var. iberoides under the same circumstances.

These experiments confirmed the supposition that there must be a minor difference in ecology between the varieties vulgare and iberoides. Possibly the explanation is to be found in the germination.

\subsection{Deviating populations of Centaurium vulgare}

In a number of localities populations of Centaurium vulgare were found, the members of which resembled in some respects the plants of var. latifolium. The plants of these deviating populations had flowers with the same light tint of roseine-purple (no. 629/2 and 629/3 of Hort. Col. Chart). These populations were found especially on old salt marshes resembling the environment of var. latifolium. In this biotope the plants exhibited the same lax habit as var. latifolium. Moreover, they made a more mesomorphous impression than var. vulgare. Because these plants did not show the most 
important feature of var. latifolium, namely the broad rosette-leaves, they could not be classed in the variety latifolium.

Such a deviating population of Centaurium vulgare was found on a salt marsh on the Westfrisian island of Schiermonnikoog, called the "Oosterkwelder". Where the vegetation of this salt marsh changes into the vegetation of the beach plain Oosterstrand near the dune ridge of the "Kobbeduinen", the plants of this population are substituted by specimens of the varieties vulgare and iberoides. Furthermore, this light-coloured paramorph was found on the salt marsh "Westerkwelder" on Schiermonnikoog and on a grazed salt marsh on the Danish Northfrisian island of Römö. The occurrence on these salt marshes suggests that the light-coloured paramorph has ecological requirements resembling those of var. latifolium.

Plants with light-coloured flowers, but otherwise resembling var. vulgare were found on the beach of Römö. Typical specimens of var. vulgare occurred here in greater numbers.

\subsection{The chromosome number of Centaurium vulgare}

The chromosome number was determined of plants collected in different populations on Terschelling and Voorne. The plants belonged to the three varieties: vulgare, iberoides and latifolium. After some preliminary determinations of plants collected by the author (carried out by Dr. Th. W. J. Gadella, Botanical Museum and Herbarium Utrecht), a more extensive study was made by Miss B. A. Brink (BRINK 1964).

In the material investigated three chromosome numbers were counted: $2 n=40,2 n=38$ and $2 n=42$. The conclusion is that Centaurium vulgare is a tetraploïd plant $(2 n=40)$. Besides, hypotetraploï $(2 n=38)$ and hypertetraploïd $(2 n=42)$ plants occur. These numbers were found in all varieties. The results agree with most records in the literature on the chromosome number of Centaurium vulgare: ZeLTNER (1962): $2 n=40$; WARBURG in MAUDe (1939): $2 n=38$ and $2 n= \pm 56$; WulfF (1937): $n= \pm 19$.

\subsection{The range of Centaurium vulgare and ssp. uliginosum}

The range of Centaurium vulgare can be divided into two parts: an atlantic area along the coasts of Northwestern Europe and a continental area. The former area will be treated first. STERNER (1940-1941) gave a distribution map of Centaurium vulgare. The map in Fig. 2 and the discussion in the present paper are based on his data and data of several authors mentioned below.

The atlantic part of the range of Centaurium vulgare was divided into the following regions: 
Fig. 2: the distribution area of Centaurium vulgare

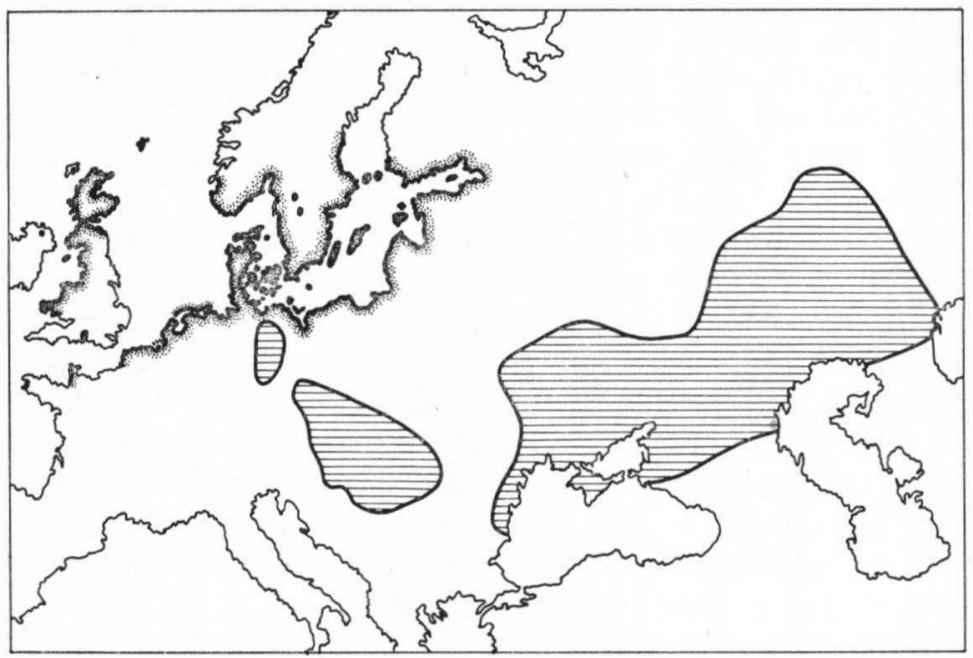

1. British Isles - lit.: Perring and Walters (1962) (1), Clapham et al. (1962).

West and north coasts from South Wales to Northumberland, one isolated spot on the south coast near Portsmouth, the north coast of Northern Ireland, the Isle of Man (1), Shetland and the Isle of Lewis (Outer Hebrides).

The Dine Centaury is not a common plant, but occurs locally. This pattern corresponds to the scattered distribution of the British dune regions along the coasts which are rocky over wide stretches. See also VAN DER MaArel and Van Der MaArel-Versluys (1963). However, not in every dune region is Centaurium vulgare to be found. Although in the BrauntonBurrows (Devon), according to the data of Willis et al. (1959), the habitat of Centaurium vulgare seems to be present, it is remarkable that the plant itself is absent.

2. Norway, Baltic region and Denmark - lit.: Hulten (1950) (1), Nordhagen (1940) (2), Shishkin and Bobrov (1952) (3), Stankov and TaliJev (1957) (4).

Coasts from Karmöy in Norway (2) to Härnösand in Sweden; from Pori in Finland to the south Russian Baltic coast $(3,4)$; coasts of Estonia, Latvia, Lithuania, Poland (not everywhere), Eastern- and Western-Germany; Denmark and all islands in this region. In the inland two localities are found on the shores of lake Vänern in Southern Sweden. According to GilLNER (1966, pers. comm.) these sites are relic salt vegetations. The northern limit of the range of Centaurium vulgare is formed, roughly speaking, by the 62nd 
degree of latitude. Also in this northern part of the range the distribution is scattered. In general the distances between the localities amount to more than $16 \mathrm{~km}(1)$.

3. Frisian Islands, the Netherlands, Belgium and France - lit.: Buchenau (1896) (1), NöLDEKE (1872-1873) (2), ChRISTIANSEN (1953) (3), RoBIJNS (1954) (4), BeEfTinK (1965) (5), BonNier (1912-1934) (6), FourNiER (1946) (7).

Coasts of Western Europe from Denmark to NW. France. Formerly Centaurium vulgare grew abundantly on the German Eastfrisian Islands $(1,2)$. On the NW. coast of the German mainland the species is very rare (3). The dune habitat for which Centaurium vulgare has a preference is scarcely developed south of the Netherlands. The species is reported for the Belgian coast (4) and for the French NW. coast $(5,6,7)$. The most southern point of the range is formed by the dunes of Manche (STERNER 1940-1941).

4. the Netherlands - lit.: HoOgENRAAD (1951) (1), Diemont et al. (1940) (2), BoerboOM $(1958,1960)(3,4)$, LateNSTEIN VAN VoORST (1958) (5), VAN Der MaARel and Londo (1960) (6).

Distribution maps (now out-of-date) were published by (1) and (2). Nowadays Centaurium vulgare occurs especially on the Westfrisian Islands in the north and on the islands in the SW. region of the Netherlands. On the mainland coast of N.- and S.-Holland the species only occurs sporadically. Formerly the species was a common feature of the wet dunes of that region. In the period in which the mainland dunes were drying out as a result of water-catchment the plant was extinguished in nearly all places (3). As a consequence of the inundation of the water-catchment areas, with river water in recent times, the species established itself again near the Hague (4) and Haarlem (5, LoNDo 1966, pers. comm.). Furthermore, Centaurium vulgare plays a part in the vegetation of the shores of a newly dug dune lake near Haarlem (6).

In the whole range discussed above Centaurium vulgare only occurs locally and the species is restricted to the available dune regions and their wet, somewhat saline slacks, as was already mentioned in connexion with the British part of the distribution range. Moreover, the species is found on the upper salt marsh. As is normal in the case of a pioneer plant Centaurium vulgare can be very abundant in places.

Apart from the Atlantic part of the distribution area, the species occurs in large regions of Mid- and Eastern-Europe. This continental part of the range comprises part of Mid-Germany, the Pannonic region inclusive Hungary, parts of Czechoslovakia, Austria, Yugoslavia and Rumania, and Southern-Russia. SHISHKIN and BoBrov (1952) mentioned a number of floristic provinces of Russia, where Centaurium vulgare occurs. More detailed, but probably incomplete records were given by STANKov and Talijev (1957). These data are consistent with those given by HermanN 
(1956), Hegi (1927) and JANChEN (1958). The occurrence of Centaurium vulgare in Russia was apparently unknown to STERNER (1940-1941) who did not include Southern-Russia in the range. Similarly WENDELBERGER (1950) erroneously classed Centaurium vulgare in the group of species which do not occur east of Transilvania.

There are not sufficient data available on the distribution of Centaurium vulgare in the continental part of the range to form a detailed picture of it. There is a second difficulty. In continental Europe a particular paramorph of Centaurium vulgare occurs. This form is characterized by the possession of papillae on the stems, the leaf-margins and the calix. In the past this form was regarded as a variety, but later it was described as subspecies uliginosum (W. et K.) Soo 1941. See e.g. Wendelberger (1950) and JANCHEN (1958). According to some authors ssp. uliginosum is the only representative of the species in continental Europe. This seems to be the opinion of: STERNER (1940-1941), RoTHMALER (1963) and JANCHEN (1958). HegI (1927), however, stated that the typical paramorph Centaurium vulgare ssp. vulgare also occurred in the inland. WENDELBERGER (1950) reported it for Bohemia. Here the typical paramorph would occur beside the ssp. uliginosum. Also the Russian floras which regard uliginosum as a species, mentioned both paramorphs with a separate distribution. The conclusion may be drawn that Centaurium vulgare ssp. vulgare and ssp. uliginosum occur together, at least in parts of the continental area.

Ssp. uliginosum seems to grow in more or less similar habitats as ssp. vulgare does. While the latter subspecies is found on saline soils near the sea, the former subspecies is restricted to saline soils in the inland e.g. in the neighbourhood of springs.

Finally attention should be drawn to the remarkable fact that ssp. uliginosum also occurs on the Swedish isles of Oland and Gotland (STERNER 1940-1941). The Swedish part of the range of Centaurium vulgare is without doubt the most interesting part in taxonomic respect because of the great variability of the species here (STERNER 1940-1941) and the occurrence of both the Atlantic and continental representatives of the species. 
Chapter 2:

\section{THE PLANT COMMUNITY OF CENTAURIUM VULGARE}

\subsection{Methods of investigation and description}

The analysis of the vegetations belonging to the plant community of Centaurium vulgare: the Centaurio-Saginetum moniliformis was carried out with single-plot analyses according to the method of BRAUN-BLANQUET (1932, 1951 and 1964). Abundance and coverage of all species of angiosperms, mosses etc. present in the stands investigated were assessed according to the following scale (see also CAIN and CASTRO 1959):

symbol abundance and/or coverage

$\begin{array}{ll}\text { r } & \text { 1 or } 2 \text { individuals and } \pm 0 \% \\ + & \text { individuals sparse and low } \\ 1 & \text { individuals plentiful (if small) or }<5 \% \text { (if large) } \\ 2 & \text { individuals very numerous (if small) or } 5-25 \% \text { (if large) } \\ 3 & \text { indifferent and } 25-50 \% \\ 4 & \text { indifferent and } 50-75 \% \\ 5 & \text { indifferent and } 75-100 \% .\end{array}$

Data on total cover, structure etc. were recorded. The sociability of the species is not treated in this study. The analyses available were combined in tables in accordance with their affinity. In addition to the analyses made by the author a number of analyses were made by students under his supervision. The results obtained by the students were published earlier in two mimeographed reports of the Botanical Museum at Utrecht (SPEKMAN and Groten 1963; De BrUYN and Borrias 1964). The first report contains the analyses of the Sagino-Cochlearietum and many of the analyses of the Centaurio-Saginetum, subass. of Sagina maritima on the Boschplaat referred to on the following pages. The second report contains analyses made on the Noordvaarder and in the area "km coast-marks 6-8", recorded here in Tables 5.

Although the author used the method of Braun-Blanquet in his field work, a more modern method was followed in the composition of his vegetation tables. His species lists were divided into sociological groups (German: soziologische Artengruppen) following the examples given by Doing (1963, 1962), Passarge (1964) and SCamoni (1963). Every group consists of species with phytosociological affinity. The species within one 
group have more or less the same sociological amplitude in the coastal area especially on Terschelling. The discussion of the vegetation tables is based on the supposition that the phytosociological amplitude of a species indicates certain ecological relations to environmental factors. For instance, the occurrence of xerosere plants is explained as an indication for a certain degree of dryness in the habitat.

The following groups occur in the tables of this chapter:

1. the differential species combination: the two name-giving species Centaurium vulgare and Sagina nodosa moniliformis, as well as Leontodon nudicaulis and Bryum angustirete. All of them are more or less restricted to the border-area of moist dune sand between dune top and dune slack. They are indicators of this habitat. They are comparable with the faithful species in older papers of the Braun-Blanquet school. The combination of these constant species typifies the Centaurio-Saginetum and differentiates this plant community from all other associations. For this reason the author has chosen the term "differential species combination" introduced by BEEFTINK (1962, 1965).

2. the halosere-group: this group consists of true halophytes and salttolerant species occurring in the halosere communities, especially in those of the salt marsh the Boschplaat. These species together indicate the salt factor in the environment of Centaurium vulgare. The more species of this group occur in a table of the Centaurio-Saginetum, the more saline this variant of the community must be. Sometimes this group is subdivided.

3. the xerosere-group: about half the number of species in the CentaurioSaginetum belongs to communities of the xerosere in the dunes of the Westfrisian Islands. They represent the dry plant communities bordering the upper limit of the Centaurio-Saginetum. Some of these species attain optimal development in young stages of the xerosere, others typify the older acid succession stages of the Terschelling-dunes.

4. the hygrosere-group: it is the opposite of group 3. In this group are comprised species found on a lower level in the dune area of Terschelling, beneath the optimal zone of Centaurium vulgare. Sometimes the selection for this group or group 5 was somewhat arbitrary as in the case of some Nanocyperion-species.

5. the mesosere-group: species e.g. meadow plants which prefer mesophytic conditions or species with about the same water-economy as Centaurium vulgare without being typical for the Centaurio-Saginetum. Their presence generally indicates the terminal stage of the pioneer community of Centaurium vulgare.

In general the species in the tables are arranged in order of decreasing presence. 


\subsection{The history of the Centaurieto-Saginetum in the literature}

It was in the Netherlands that the plant community of Centaurium vulgare was first described as Centaurieto-Saginetum moniliformis and later on much attention has been given to the association in this country especially by Westhoff. From these facts we may conclude, that this plant community attains a high development just here. This section gives a survey of the development in the description of the association. As was done already in section 2.1 the shortened name Centaurio-Saginetum will be used in the text henceforward.

The first - vague - information about plant communities with Centaurium vulgare is found in the paper of BRAUN-BLANQUET and De LEEUW (1936). In their description of the vegetation of the Westfrisian island of Ameland they mentioned a community of Gentiana (amarella) uliginosa and Erythraea littoralis ( $=$ Centaurium vulgare) belonging to the Nanocyperion-alliance. The composition of this community is about the same as that of the community of Centaurium latifolium described below. Moreover, they gave a short description of a vegetation with Juncus bufonius, Sagina nodosa, Erythraea littoralis etc. also belonging to the Nanocyperion and occurring in an older stage of the halosere. These two communities were treated separately as independent units.

DiEmont et al. (1940) published a monographical essay on the alliance Nanocyperion flavescentis in the Netherlands: a group of plant communities consisting for the greater part of therophytes and occurring on temporarily bare spots with a moist sandy soil. One of the plant communities described was a new association called Centaurieto-Saginetum moniliformis, characterized by the species Centaurium vulgare and Sagina nodosa moniliformis. Only the wet subassociation samoletosum was described in detail, some halophytes and hygrophytes were recorded as differential species: Samolus valerandi, Glaux maritima, Nostoc sp. Blackstonia perfoliata was considered to be a possible faithful species for the SW. region of the Netherlands. Rather wet and somewhat saline dune sand with $\mathrm{pH}= \pm 7$ was supposed to be the environment. In the vegetation table the following species were mentioned as faithful species of the alliance: Juncus bufonius, Centaurium pulchellum, Gnaphalium luteo-album and uliginosum, Carex serotina pulchella, Centunculus minimus, Plantago intermedia and Sagina procumbens.

In 1946 WesthoFF et al. gave a survey of all known associations in the Netherlands. Again the Centaurio-Saginetum was recorded as an association of the Nanocyperion. For a great part the descriptions of the Nanocyperioncommunities were based on an earlier paper (DiEmont et al. 1940). Some facts regarding the Centaurio-Saginetum were new. Carex serotina pulchella was added as a faithful species. Furthermore, details were given on another subassociation: thrincietosum. As differential species of this dry subassociation 
some dry dune plants were mentioned: Leontodon nudicaulis, Hieracium umbellatum, Cerastium atrovirens. According to this paper the dry variant normally occurred on rather dry slopes of dune slacks poor in organic matter and with an almost desalinated soil.

In his excellent thesis on the vegetation of the Westfrisian Islands WESTHOFF (1947 b) gave the most detailed and thorough description of the Centaurio-Saginetum. Here we also find the complete and original description of the dry subass. thrincietosum. Earlier, more fragmentary descriptions are incorporated in it. The differences between the two subassociations become clearer. Subass. thrincietosum is a pioneer community of moist dune slopes and subass. samoletosum occurs on open patches in terminal stages of the halosere, for instance in the Junceto-Caricetum extensae. The latter subassociation is, therefore, typified by wetter, more saline soils with a higher content of organic materials. A new element in the association was formed by the faithful species Bryum warneum. In the vegetation table of the first paper (1940) Bryum cf. pendulum (= angustirete) was a companion with a high presence.

In a description of plant communities of the island of Goeree WESTHOFF et al. (1961) comprised vegetations with Centaurium vulgare and Sagina nodosa within a plant community of Sagina maritima. Centaurium vulgare and Sagina nodosa were regarded as faithful species of this community. Little value was attached to the Centaurio-Saginetum as a separate association. Moreover, the authors expressed their doubts about the affinity of the "former" Centaurio-Saginetum to the Nanocyperion-alliance. Apart from these syntaxonomic problems the existence of an ecological relationship between Centaurium vulgare and Sagina maritima is suggested in this paper.

Finally the present author refers to a recent paper by VAN DER MAAREL and WESTHOFF (1964) giving a survey of vegetation-types occurring in a part of the Voorne-dunes. The authors left the classical treatment and classification method of Braun-Blanquet. Plant communities were typified by indicator species of different nature. They mentioned the community of Centaurium littorale ( $=$ vulgare) and Sagina nodosa. Two other species namely Blackstonia perfoliata and Gnaphalium luteo-album were also mentioned as indicator species of this community. They distinguished a wet and a dry variant corresponding to the above-mentioned subassociations. This plant community was classified as belonging to a dune slack pioneer formation.

\subsection{Investigations on Terschelling}

\subsubsection{The typical Centaurieto-Saginetum}

The composition of the typical Centaurio-Saginetum is shown in Table 1 consisting of seventeen single-plot analyses. They were made in the summer of 1962 in a series of artificial small dune slacks situated between $\mathrm{km}$ coast- 
marks 17 and 20 behind the coastal ridge. In these slacks, dug out in 19561957, the Centaurium-community forms a marked transition between the vegetation of the wet slack, on the lower side, and the dry vegetation with planted tussocks of Ammophila arenaria or sometimes Corynephorus canescens, on the upper side. In Table 1 the analyses are arranged in order of decreasing number of xerosere-species. On the basis of the indication value of the xerosere-group this sequence designates the gradient from high and dry to low and wet Centaurium-habitats. All plots were $2 \times 2 \mathrm{~m}^{2}$ and some of them formed belt transects across the zonation.

In the differential species combination the abundance of Centaurium vulgare shows an interesting trend: columns $1-5$ total estimate $=1$, columns $6-11=2$ and columns $11-17=$ again 1 . This means that Centaurium is represented by viz. a low number of big specimens, a high number of smaller individuals and small plants with low density. This variability is not accidental, but it parallels the shift from dry to wet environments. Sagina moniliformis is nearly always present with varying abundance and coverage. In general it attains highest development somewhat lower on the slope than Centaurium, but the zones and the environments of both species are for a great part the same. In the dune habitat both species form a close combination and it is justified to regard them together as the most important indicator species of the community, as was done from the beginning. Leontodon nudicaulis has a great amplitude as to water tolerance. It occurs in many communities of the xerosere and it is generally considered as a member of the xerosere. However, this species may also occur on the wet bottom of the slack. The Centaurio-Saginetum forms more or less the middle of the range which Leontodon occupies on the dune slopes. Besides, it attains its optimal development in the Centaurio-Saginetum. For the author these facts made him place this plant in the differential species combination. Outside the coastal region Leontodon nudicaulis is found in several different habitats e.g. along roads. It is possible that the dune paramorph of this apogamic species is a separate ecotype (WESTHOFF 1963, pers. comm.).

Bryum angustirete is a moss which prefers open moist sandy places in the inland as well as in the dunes. In the dune area this habitat of Bryum is for a great part the same as that of Centaurium. However, Bryum may also form pioneer vegetations on the bottoms of very young dune slacks. In that case it attains a high coverage on wetter ground on a lower level than the Centaurio-Saginetum has. We may say that the upper limit of Bryum angustirete lies in the community of Centaurium vulgare. Of all bryophytes it is the most constant species in the Centaurium-community. For fixing the loose sandy soil surface it is very important. In most papers on the CentaurioSaginetum a Bryum species was mentioned as a constant member of the community investigated. In many cases the epithet was not given at all or given with the addition "cf.". The explanation is simple. Often Bryum 
Table 1: Centaurieto-Saginetum moniliformis in dune slacks between $\mathrm{km}$ marks 17 and 20

No. of column

$\begin{array}{lllllllllllllllll}1 & 2 & 3 & 4 & 5 & 6 & 7 & 8 & 9 & 10 & 11 & 12 & 13 & 14 & 15 & 16 & 17\end{array}$

No. of analysis

Total cover in \%

30222331 IIA IIB 32a M1 IA IB IIC 24 M3 ICIIDM2 ID

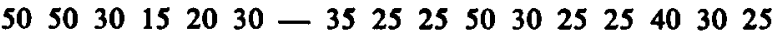

differential species combination

Centaurium vulgare

Sagina nodosa monilif.

Leontodon nudicaulis

Bryum angustirete

xerosere

Rumex acetosella

Jasione montana

Viola tricolor curtisii

Corynephorus canescens

Tortula ruralis rural.

Taraxacum sp.

Sedum acre

Elytrigia juncea

Aira praecox

Phleum arenarium

Lotus corniculatus corn.

Cerastium semidecandrum

Poa pratensis

Sonchus arvensis

Anthyllis vulneraria

Cerastium atrovirens

Hieracium umbellatum

Ammophila arenaria

Hippophaë rhamnoides

Carex arenaria

Festuca rubra arenaria

\section{hygrosere}

\section{Salix repens}

Agrostis stolonifera ar.

Juncus artic./alpinus

Calamagrostis epigejos

Nostoc sp.

Carex serotina pulch.

Carex flacca

Parnassia palustris

Hydrocotyle vulgaris

Juncus bufonius

Radiola linoides

Rhinanthus minor minor

Holcus lanatus

Euphrasia officinalis \begin{tabular}{rrrrrrrrrrrrrrrrr}
1 & 1 & 1 & 1 & 1 & 2 & 2 & 2 & 2 & 2 & 2 & 1 & 1 & 1 & 1 & + & 1 \\
+ & 2 & - & 1 & $r$ & 2 & $r$ & 1 & + & 2 & 1 & - & 1 & 1 & $r$ & + & 1 \\
\hline & $\mathbf{r}$ & + & - & + & + & 1 & 1 & 1 & 1 & 2 & $\mathbf{r}$ & 1 & 2 & 1 & 1 & 2 \\
1 & 1 & 1 & + & - & 1 & 1 & + & - & 1 & 2 & 1 & 2 & - & ++ & 1
\end{tabular}

r $1-+--------1-$

$++\mathbf{r}-1-\ldots-\ldots-\ldots$

r $\mathbf{r} \mathbf{r}+--------\cdots$

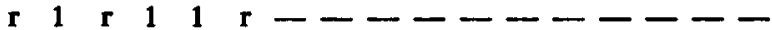

$---+++-----\cdots$

$-----\frac{\mathrm{r}}{\mathrm{r}}-------$

$------1-----\mathbf{r}----$

$-\mathbf{r}-+--+------$

--+--+ r $1------\frac{1}{1}$

$--1 \mathrm{r}-\mathrm{r}---\mathrm{r}-\mathrm{r}-1-$

$1+11---\mathrm{r}+-----\ldots$

$-1++--r$ r $---+-r--$

$1-+---1$ r $-\mathrm{r}--+--\mathrm{r}-$

$-1-r-2-r 1+r+----$

$1 \quad 1 \quad r \quad 1 \quad 1-1-1+----\cdots$

$+-+-++r+r+r r----$

$2-2-+1121 r+2--r--$

$r \mathbf{r}+\mathbf{r}+\mathbf{r}+-\mathbf{r} 1-\mathbf{r} 1+-$

$22+1++r--++11+1+1$

$212+\begin{array}{lllllll}2 & 2 & 2 & 2 & 2 & 2 & 2\end{array}$

r $\mathrm{r}+--\mathrm{r}-+--11 \mathrm{r}+321$

$--1+-1-+--1-1 \quad 11+1$

$---r-1-r-+1 r-1 \quad 112$

$-+r+---r-1-r---1-$

$-1-1-1----3-+-1+1-$

$-----1----\frac{-1}{-1}+1+1$

$--------+--1+$

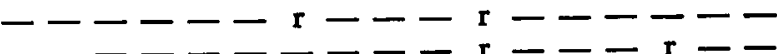

$-\bar{r}=-\overline{-}-----1---1$

$--------1+--1-$

$-\pi \mathrm{r}-12--+1$ r $\mathbf{r}-\mathrm{r}-+$

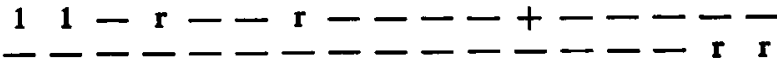

(Addenda of Tables 1, 2, 3 and 4 on page 58) 
angustirete does not bear sporogons making identification almost impossible. Also in Belgium the moss is typical for the Centaurio-Saginetum. We may conclude that Bryum angustirete is a typical species of the CentaurioSaginetum and that its place in the differential species combination is justified.

In Table 1 - as well as in Table 2 - the xerosere plants are listed in order of increasing presence. Consequently the constant species of xeroseregroup and hygrosere-group, which form the bulk of the community - in addition to the differential species combination - stand together. This sequence in the species list, together with the sequence of the analyses from dry to wet, gave sufficiently surveyable tables.

It is obvious that the Centaurio-Saginetum situated at the lower edge of the xerosere is a marginal environment for the typical xerosere plants. Presence and total estimate of these xerophile species in Table 1 is low and in the wet analyses their number is very low. The composition of the xerosere-group depends upon that of the surrounding vegetations, distance from the sea, age of the site etc. Species as Rumex, Jasione, Viola and Corynephorus only occur, when the Centaurio-Saginetum borders on communities of the grey dunes. Ammophila attains a rather high total estimate in some analyses of Table 1, because the Marram grass was planted on these spots. The most important species of the xerosere-group is Festuca rubra ssp. arenaria. It is a constructive plant in young stages of the xerosere. In the Centaurio-Saginetum it is generally the species with the highest dominance. See also FreiJsen and VAN Heusden (1965).

The hygrosere-group is the opposite of the xerosere-group. The species belonging to the former group occur in the slacks and on the lower parts of the slopes. In the zone of Centaurium vulgare they are found with reduced vitality. Salix repens is the least pronounced hygrosere plant, because paramorphs of this species may also grow in very high and dry places in the duneland. However, in general it seems well classed in the hygrosere. Agrostis stolonifera var. arenaria attains highest development on the bottoms of young sandy slacks. Juncus articulatus and alpinus atricapillus were combined in the species list because it was often impossible to make a distinction due to the absence of inflorescences. Carex serotina pulchella only occurs in the wettest vegetations of Centaurium vulgare. This situation is the same for the whole Dutch coast. It is not correct to regard it as a faithful species of the Centaurio-Saginetum. According to the literature Carex pulchella belongs to the Nanocyperion together with Juncus bufonius andRadiola linoides. Formerly their (low) presence in the community of Centaurium vulgare was one of the reasons to class this community in the Nanocyperion.

The occurrence of hygrosere and xerosere plants together typifies the Centaurio-Saginetum. In addition to the differential species combination the 
plant community of Centaurium vulgare is characterized by this composition of wet and dry plants with reduced vitality.

\subsubsection{The subassociation of Sagina maritima}

The second object of the vegetation studies were the vegetations of the Centaurio-Saginetum on the salt marsh the Boschplaat particularly on the horseshoe dunes. The environmental factor salt $(\mathrm{NaC1})$ is important here and it strongly influences the floristic composition of the community. The results are shown in Table 2 . This table contains fifty analyses made by the author (F) and by Spekman and Groten (S). Data on coverage of herbs, mosses and lichens are mentioned in the head of the table. The total coverage in these vegetations is much higher than in the typical Centaurio-Saginetum. The names of the lichens are recorded in the addenda. They are generally tiny and not fully developed in this community. The analyses are arranged in order of increasing number of halophytes and decreasing number of dune plants.

The presence of Leontodon nudicaulis and Bryum augustirete is lower than in Table 1. Bryum is inconspicuous in the Centaurium-vegetations on the Boschplaat, several other mosses, however, were found. On the whole the differential species combination plays the same part as in the typical Centaurio-Saginetum.

The xerosere-group resembles that of Table 1. There are also slight differences in presence and the species of the grey dunes, Corynephorus etc. are absent. Cerastium atrovirens, Festuca arenaria and Sedum acre are constant species, all other plants have a low presence and low total estimates.

To get more information on the xerosere on the Boschplaat the reader is referred to Table 2a. This consists of three vegetation analyses made on tops of horseshoe dunes. It gives an impression of an important community occurring "above" the Centaurio-Saginetum on the Boschplaat. The species were divided into the same floristic groups as in the other vegetation tables in order to facilitate the comparison. The use of the term "differential species combination" is otherwise meaningless. This community dominated by Festuca arenaria, Brachythecium albicans and Anthyllis vulneraria can be classed into the alliance Koelerion albescentis. Although the salt marsh as a whole is a very dynamic region, the vegetations on tops of horseshoe dunes are rather fixed. The sand dike in the northern part of the Boschplaat built in the period 1931-1938 (VISSER 1947) prevented the invasion of water from the North Sea and the supply of sand from the beach. The vegetation above the storm-flood line of the Wadden Sea could develop into a more stable complex. Table 2a also serves as a vegetation record for a soil sampling site.

The great difference between the Tables 1 and 2 is found in the lower halves. The hygrosere of Table 1 is substituted by the halosere: true 
No. of column

No. of analysis Author
Area in $\mathrm{m}^{2}$

Area in $\mathbf{m}^{2}$
Cover of herbs in $\%$ Cover of mosses in $\%$ Cover of lichens in $\%$

differential species combination

Centaurium vulgare
Sagina nodosa monilif. Sagina nodosa monilif.
Leontodon nudicaulis Bryum angustirete

xerosere

Hypnum cupressiforme
Arenaria serpyllifolia Taraxacum sp.

Eryngium maritimum Tortula subulata

Trifolium arvense

Tortula ruralis ru
Carex arenaria

Carex arenaria
Hieracium umbellatum

Sonchus arvensis

Poa pratensis

Aira praecox

Brachythecium albicans

Cerastium semidecandru
Hippophaë rhamnoides

Hippophaë rhamnoides
Anthyllis vulneraria

Ammophila arenaria
Camptothecium lutescens

Sedum acre

Festuca rubra arenaria

halosere

Sagina maritima

Plantago coron
Pottia heimii

Agrostis stolonifera sal.

Plantago maritima

Armeria maritima

Elytrigia pungens
Festuca rubra litoralis
Euphrasia odontites

Limonium vulgare

Parapholis strigosa

Centaurium pulchellum

Carex extensa

Artemisia maritim

Glaux maritima

Triglochin maritima

Cochlearia anglica
Spergularia marginata

Trifolium repens

Nostoc sp.

Trifolium pratense
Juncus articulatus

Leontodon autumnalis
Calamagrostis epigejo

Linum catharticum

Parnassia palustris
Cephaloziella hampeana $\begin{array}{llllllllllllllllllllllllllllllllllllllllllllllllllllllllllllllllll}1 & 2 & 3 & 4 & 5 & 6 & 7 & 8 & 9 & 10 & 11 & 12 & 13 & 14 & 15 & 16 & 17 & 18 & 19 & 20 & 21 & 22 & 23 & 24 & 25 & 26 & 27 & 28 & 29 & 30 & 31 & 32 & 33 & 34 & 35 & 36 & 37 & 38 & 39 & 40 & 41 & 42 & 43 & 44 & 45 & 46 & 47 & 48 & 49 & 50 & \text { No. of column }\end{array}$

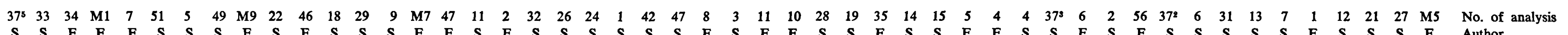

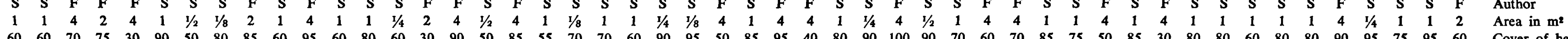

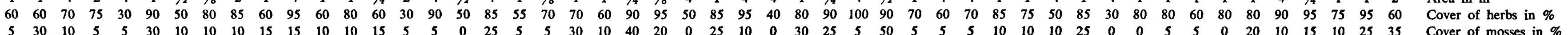

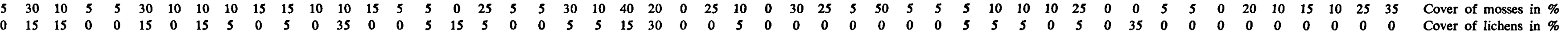

$+$

$\begin{array}{ccccccccccccccccccc}+ & + & 1 & + & 2 & + & 1 & 1 & 1 & + & 1 & 2 & 2 & 1 & 2 & 1 & 1 & 2 & + \\ 1 & 1 & 1 & + & 2 & 2 & 1 & 2 & 2 & 1 & 1 & 1 & 2 & 3 & + & + & 2 & 1 & - \\ 2 & 1 \\ 2 & + & 1 & 1 & - & 1 & 2 & - & 2 & 2 & 2 & 2 & - & 2 & \mathrm{r} & \mathrm{r} & 1 & + & 2 \\ - & - & - & - & - & + & - & - & 1 & - & - & - & - & + & \mathrm{r} & - & 2 & - & 2\end{array}$

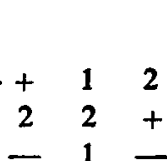

$\begin{array}{rrr}1 & 1 & + \\ 2 & 2 & 2 \\ - & + & 1\end{array}$

$12+1$

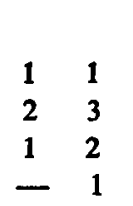

$\begin{array}{lll}3 & 1 & 1 \\ 2 & 1 & 1 \\ 1 & +\end{array}$

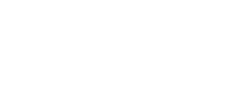

$1 \quad 2$

$++3111$

differential species combinat
Centaurium vulgare

Centaurium vulgare
Sagina nodosa monilif.
Leontodon nudicaulis

Leontodon nudicaulis
Bryum angustirete

xerosere

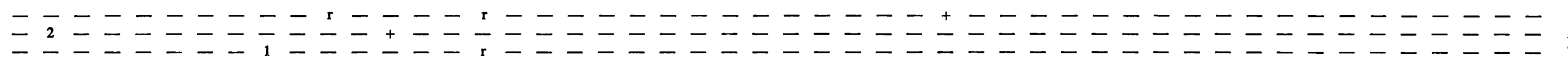

Hypnum cupressiforme
Arenaria serpyllifolia

Arenaria serpyllifolia
Taraxacum sp.

Taraxacum sp.
Eryngium maritimum

Lotus corniculatus $\mathrm{co}$
Tortula subulata

Trifolium arvense

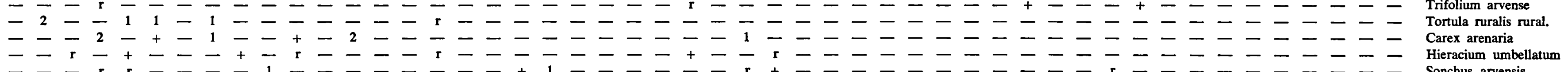

Zニ

- ニニニニニニ 一

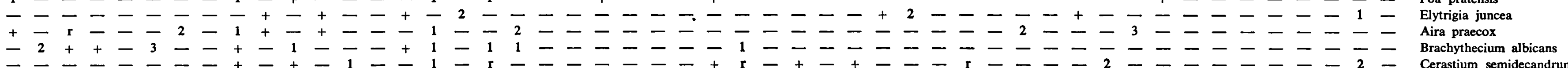

Z

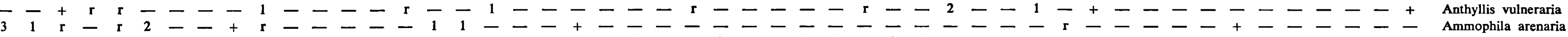

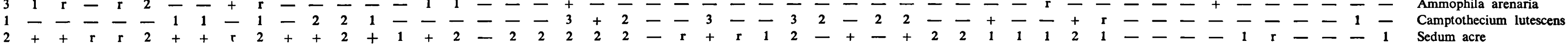

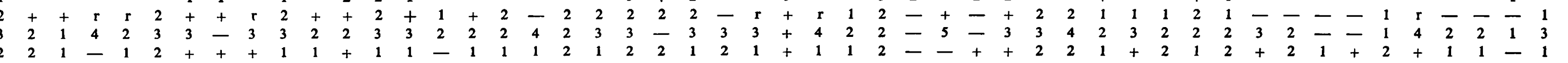

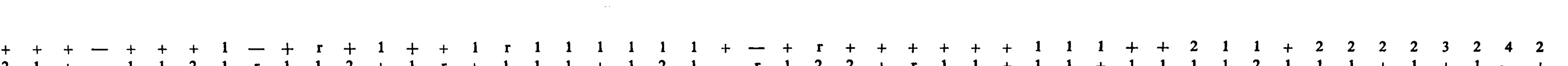
Festuca rubra arenaria

halosere

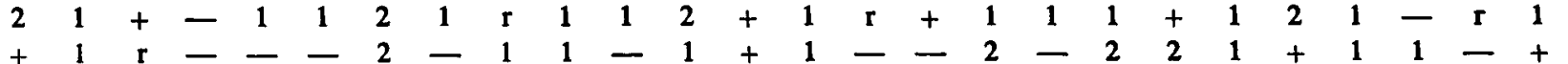

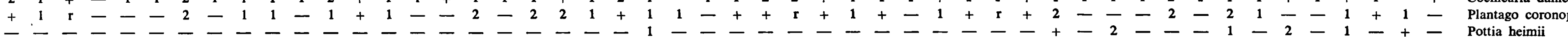

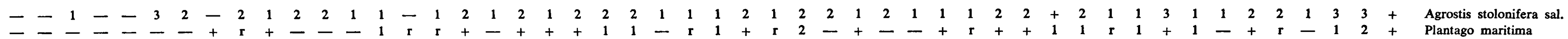

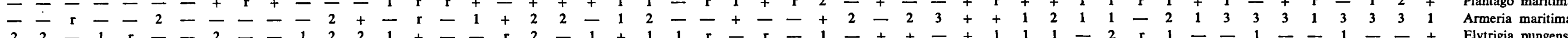

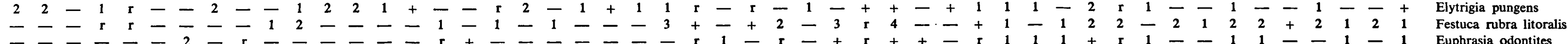

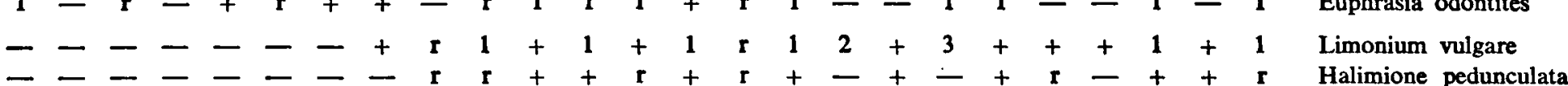

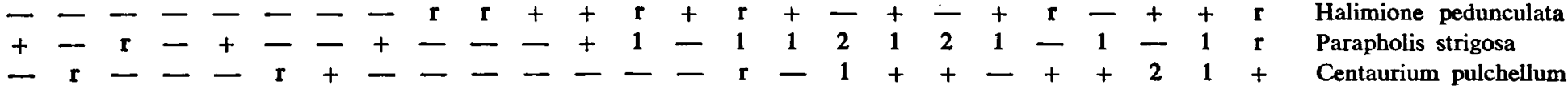

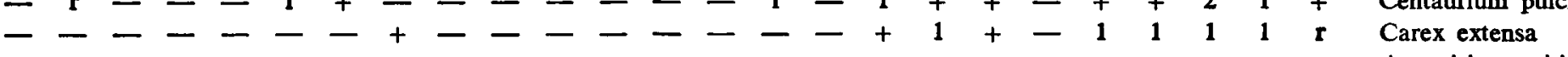

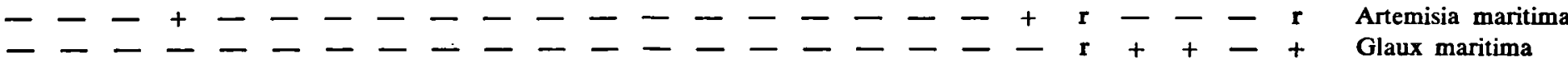

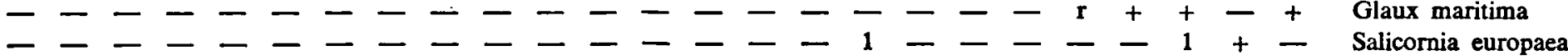

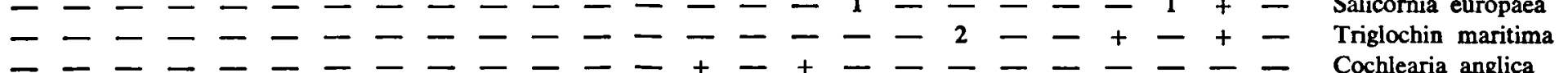

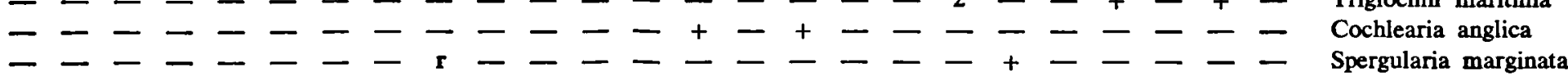

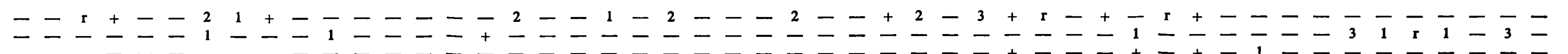
Trifolium repens Nostoc sp. Juncus articulatus Leontodon autumnalis Calamagrostis epigejos Linum catharticum
Parnassia palustris Parnassia palustris
Cephaloziella hampeana

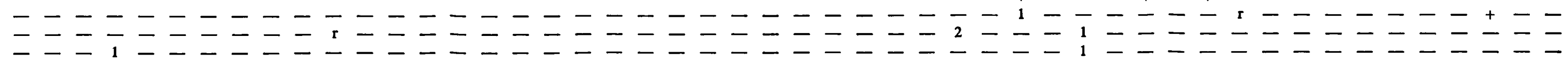

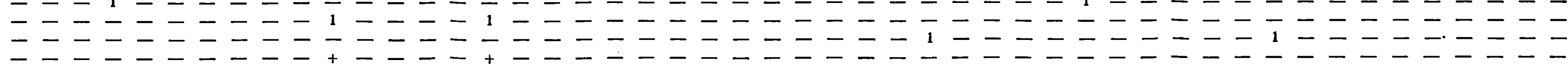


Table 2a: the plant community on tops of horseshoe dunes

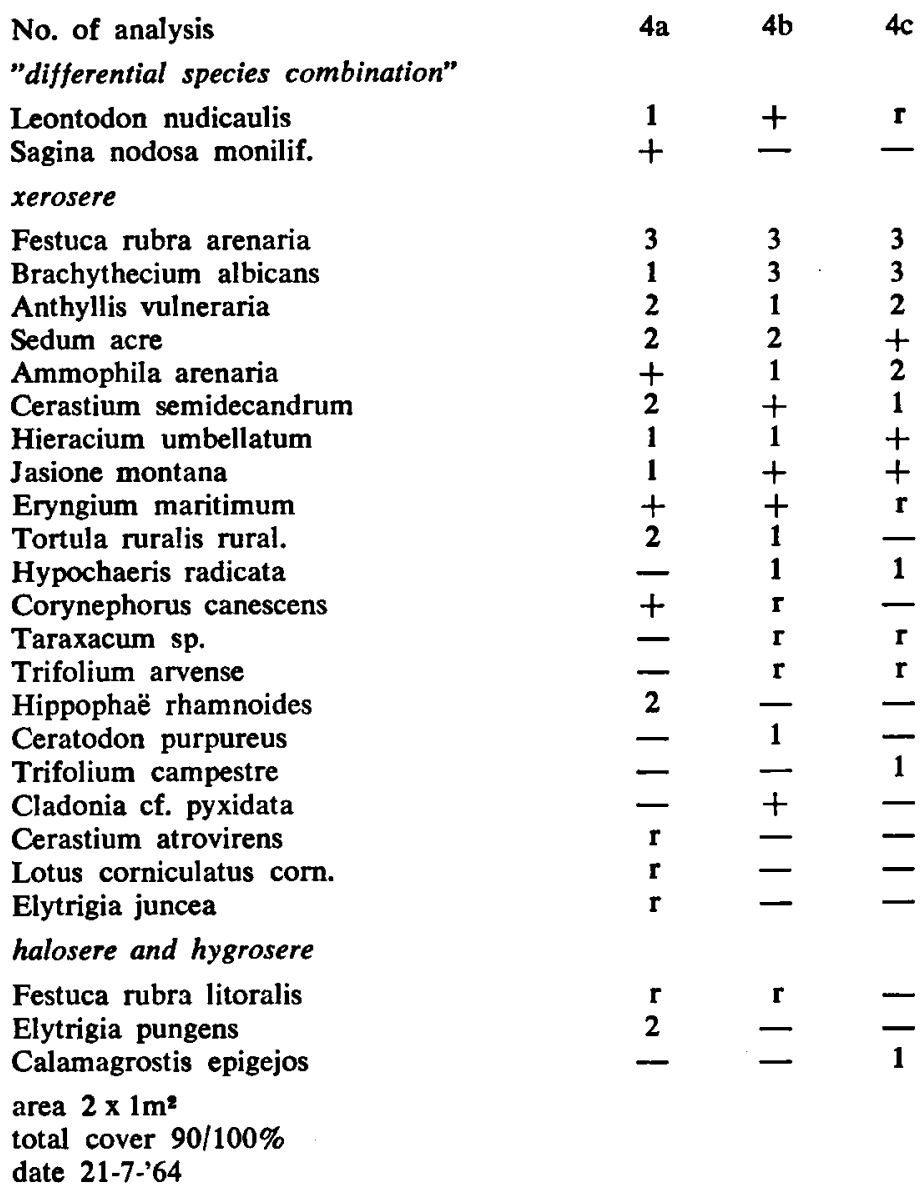

halophytes or salt tolerant species occurring in the saline vegetations of the Boschplaat. This halosere is subdivided into three groups. The first subgroup consists of four species: Sagina maritima etc. belonging to the ass. SaginoCochlearietum. The abundance of these species makes it clear that there is a strong relation between our community and the Sagino-Cochlearietum. The second subgroup is composed of species occurring in the "highest" Armerion maritimae-communities of the Boschplaat. They can be comprised in the ass. Juncetum gerardii. These vegetations, dominated by the grasses $A$ grostis stolonifera salina or Festuca rubra litoralis, are situated just above the springtide level and border on the Centaurio-Saginetum. The third subgroup consists of species occurring in e.g. the Junceto-Caricetum extensae and the 
Puccinellietum maritimae pholiuretosum. These communities cover a large area on the Boschplaat between the sand dike in the north and the dunegroups in the south. Limonium vulgare and the other members of this subgroup characterize the wet and more saline variant of the Centauriumcommunity on the Boschplaat. They are absent in the dry variant in which a greater number of xerophytes occurs.

The substitution of the hygrosere by the halosere is the most important feature of the Centaurio-Saginetum on the Boschplaat. The difference in the floristic composition and ecology seems great enough to justify a separation from the typical Centaurio-Saginetum. The author suggests to consider the community of Centaurium vulgare on the Boschplaat and similar saline forms elsewhere as a subassociation: Centaurieto-Saginetum moniliformis subass. of Sagina maritima Freijsen subass. nov. Differential species are all halophytes, to begin with Sagina maritima.

Vegetations of the Sagino-Cochlearietum are found on open spots within Armerion-communities on the Boschplaat and elsewhere (TüxeN and coll. 1957, Westhoff et al. 1961, TüXen and Westhoff 1963, BeEFTinK 1965, SPEKMAN and Groten 1963). They occur locally in the generally dense sward formed by Festuca litoralis around the foot of horseshoe dunes. Here, the Sagino-Cochlearietum may gradually change into the adjacent community of Centaurium vulgare, so that it is impossible to draw a strict dividing line between both communities. With regard to the occurrence on the Boschplaat the wet saline variant of the Centaurio-Saginetum and the dry form of the Sagino-Cochlearietum, the subass. sedetosum, may be regarded as being identical. The floristic composition of other forms of both communities is different enough to enable a distinction. For instance, Sagina maritima is only rarely found in the typical Centaurio-Saginetum; Centaurium vulgare is generally absent in the Sagino-Cochlearietum. Further similarities and differences are shown in Table 5A. The floristic similarity of "extreme" forms of both associations agrees with an ecological resemblance between these forms in particular and between both associations in general. The environments of Centaurium vulgare and Sagina maritima are situated in the ecotone between dry and wet (saline) habitats and they are typified by fluctuating environmental factors. The structure of their vegetations is similar; these are open and they consist of species with a short life-cycle.

Table $2 b$ shows the composition of a plant community occurring at the foot of the sand dike on the Boschplaat. The water and salt conditions of this environment are influenced by fresh seepage water from the dike. The Agropyro-Rumicion species Leontodon autumnalis and Trifolium repens indicate this disturbance. Parnassia palustris and Juncus alpinus atricapillus are notable species. This community belongs to the Juncetum gerardii subass. of Leontodon autumnalis. Centaurium vulgare can hardly grow in this transitional stage between halosere and hygrosere, because the moisture 
Table 2b: transition vegetation between halosere and hygrosere

No. of analysis

$2 \mathbf{a}$

2b

"differential species combination"

Centaurium vulgare rosettes

Centaurium vulgare adult plants

Sagina nodosa moniliformis

Leontodon nudicaulis

Bryum angustirete

(1)

halosere

Festuca rubra litoralis

Agrostis stolonifera salina

Centaurium pulchellum

Triglochin maritima

Euphrasia odontites

Glaux maritima

Plantago maritima

Limonium vulgare

Juncus gerardii

Armeria maritima

Carex extensa

hygrosere

Nostoc sp.

Parnassia palustris

Juncus alpinus atricapillus

Trifolium repens

Schoenus nigricans

Didymodon tophaceus

Leontodon autumnalis

Carex flacca

xerosere

Festuca rubra arenaria

Brachythecium albicans

Hippophaë rhamnoides

$\begin{array}{ll}1 & 1 \\ \mathbf{r} & \mathbf{r} \\ 1 & 1 \\ 1 & 1 \\ + & 2\end{array}$

area $2 \times 1 \mathrm{~m}^{2}$

total cover $100 \%$

date 21-7:'64

content is too high. The number of its seedlings is low and their mortality high. The spot of analyses $2 a$ and $2 b$ was a soil sampling site.

\subsubsection{Centaurium vulgare in a secondary habitat}

On small spots in and around the summer resort Midsland-aan-Zee especially in places where sods were cut, the community of Centaurium 
Table 3: Centaurieto-Saginetum moniliformis with 3 paramorphs of Centaurium vulgare

No. of analysis

Area in $\mathrm{m}^{8}$

Total cover in $\%$

Cover of algae in \%

differential species combination

Centaurium vulgare latifolium

$$
\begin{array}{lll}
" & " & \text { vulgare } \\
" & \text { iberoides } \\
" & \text { " } & \text { rosettes }
\end{array}
$$

Leontodon nudicaulis

Bryum angustirete

xerosere

Cerastium semidec./holosteoides

Lotus corniculatus corniculatus

Hypochaeris radicata

Festuca rubra arenaria

Aira praecox

Festuca ovina

Trifolium campestre

Poa pratensis

Brachythecium albicans

Hypnum cupressiforme

Carex arenaria

hygrosere

Carex trinervis

Salix repens

Juncus alpinus atricapillus

Juncus bufonius

Juncus articulatus

Cephaloziella hampeana

Didymodon tophaceus

Radiola linoides

Empetrum nigrum

Calluna vulgaris

Carex flacca

Calamagrostis epigejos

mesosere

Holcus lanatus

Polygala vulgaris

Rhinanthus minor minor

Sagina procumbens

Trifolium repens

Trifolium pratense

Taraxacum sp.

Luzula campestris

date 6-8-'64

$\begin{array}{cccc}11 & 08 & 10 & 09 \\ 1 \times 1 & 1 \times 3 & 2 \times 1 & 2 \times 1 \\ 60 & 75 & 45 & 25 \\ 70 & 50 & 60 & 60\end{array}$

$\begin{array}{lccc}2 & 2 & + & - \\ \mathbf{r} & + & + & + \\ \mathbf{r} & + & + & 2 \\ 2 & 1 & + & + \\ 1 & + & 1 & 1 \\ 1 & - & 1 & 1\end{array}$

$\begin{array}{llll}+ & + & \mathbf{r} & + \\ 1 & 2 & 1 & + \\ + & 2 & 1 & \mathbf{r} \\ + & + & 1 & - \\ + & 1 & \mathbf{r} & + \\ + & + & - & + \\ + & - & + & + \\ + & 1 & - & - \\ + & + & - & \mathbf{r}\end{array}$

$\begin{array}{llll}1 & 1 & 1 & + \\ 1 & + & 1 & 1 \\ 1 & + & 1 & + \\ 1 & + & + & + \\ + & + & + & 1 \\ 1 & - & + & r \\ + & + & 2 & - \\ + & - & r & + \\ + & - & r & + \\ 1 & 1 & + & + \\ - & - & + & +\end{array}$

$\begin{array}{llll}1 & + & 1 & 1 \\ + & + & + & + \\ + & + & + & + \\ 1 & \frac{1}{r} & + & \frac{1}{1} \\ + & - & \frac{1}{r} & + \\ + & - & - & -\end{array}$


vulgare occurs with a peculiar composition. Table 3 shows four analyses from a site in the dune valley "Meesterplak". This site was surrounded by the original vegetation consisting of dune heath plants and it resembled the normal Centaurio-Saginetum in openness and distance from the sea.

About the composition of the vegetation of Table 3 the following can be said. The first notable phenomenon is the high coverage of algae. In the differential species combination some remarkable items draw the attention. Sagina nodosa is absent. The species Centaurium vulgare, however, is represented by three paramorphs. Centaurium var. latifolium attains highest density. The total estimate of Centaurium vulgare var. vulgare is as low as t. The third paramorph is Centaurium var. iberoides. Var. latifolium seems to have a preference for this type of habitat, as will be seen in the next section, but the ecological tolerance of the var. iberoides is about the same as that of var. vulgare. Both these forms can attain higher abundance in the typical Centaurio-Saginetum characterized by primary open young sandy soils.

It is conceivable that in the xerosere group some species of the yellow dunes are absent e.g. Ammophila, Cerastium atrovirens, Sonchus, Sedum etc. They are substituted by plants occurring in the surrounding older communities of the dunes in the area of Midsland-aan-Zee e.g. Hypochaeris and Festuca ovina. Almost the same is true for the hygrosere group in which are found, as elements of the dune heath, Carex trinervis, Empetrum and Calluna. Furthermore, there are Juncus bufonius and Radiola. These species indicate a certain degree of similarity between this community and the Nanocyperion.

A greater difference between this community and the normal CentaurioSaginetum is formed by a rather important mesosere-group. These plants prefer mesophytic environments and they are not restricted to the coastal area. Sagina procumbens is a tread plant belonging to the association: SaginoBryetum (Plantaginetea maioris). The spot investigated was used as a parking place for cars. So the occurrence of this species in this place can be regarded as quite normal.

In several other places along the north coast of Terschelling fragments of the "secondary" Centaurio-Saginetum are found. Everywhere the existing vegetation is disturbed by man or animals and a secondary new open environment is created, Centaurium vulgare may occur in a vegetation which resembles that of Table 3 in one or more respects. These fragments on paths, tracks and bare places form the outposts of the area of the halophilous pioneer plant Centaurium vulgare. 


\subsubsection{Vegetations with Centaurium latifolium}

The analyses of Table 4 were made in transition stages between the halosere and the hygrosere on the Groene Strand near the village of WestTerschelling (columns 1 - 6) and the St. Janshoek, a part of the Groede (columns 7 - 8). Both areas used to be grazed by cattle and horses. The former area is disturbed in many ways, among other things by sod cutting, treading, picknicking etc. Besides, both areas are inundated a few times a year by storm-floods.

In the differential species combination Sagina nodosa is absent as Centaurium vulgare var. vulgare in most of the analyses. Instead of this typical paramorph Centaurium vulgare var. latifolium occurs. Adult plants and rosettes of this variety are mentioned separately.

The normal characteristic combination of species of the CentaurioSaginetum is not present in Table 4 because the xerosere is lacking. Only the hygrosere and the halosere are well-developed. In this respect Table 4 resembles Table $2 \mathrm{~b}$. This is clear in the light of the similar transitional nature of these communities. The hygrosere is subdivided as follows. In the first subgroup, called Nanocyperion-group, are classed a number of species belonging to this alliance according to the paper of DiEMONT et al. (1940). Also in more recent papers these species are classed in the Nanocyperion or in the higher unit Isoëtetalia. See BRAUN-BLANQUET et al. (1952), WESTHOFF et al. (1946), Oberdorfer (1957) and Passarge (1964). As was mentioned in the preceding section Sagina procumbens belongs to the Plantaginetea maioris, but it is a common plant in Nanocyperion-associations too. But for the vegetation of column 6 this community with Centaurium latifolium possesses a strong relation with the Nanocyperion.

The second hygrosere subgroup consists of Eleocharis quinqueflora and Campylium polygamum. According to WESTHOFF et al. (1961) these species belong to the alliance Caricion davallianae. This is an alliance of communities occurring in calcareous marshes. In our table these two species differentiate the columns 1 - 5 from $6-8$. There is, indeed, an obvious difference in wetness between the vegetations represented by the groups of columns just-mentioned. However, all vegetations recorded in Table 4 are characterized by a low $\mathrm{CaCO}_{3}$ content. The last subgroup consists of species which were already mentioned in previous tables. Finally, some remarks on the mesosere can be made. Trifolium repens, Leontodon autumnalis and Potentilla anserina - considered as Agropyro-Rumicion species - indicate the dynamic and disturbed situation of this community. For practical reasons Brachythecium, Poa and Lotus were placed in this group too.

The close relation between this community and the Nanocyperion has already been mentioned. The vegetation of the columns 1-5 closely resembles the Cicendietum filiformis subass. isolepetosum setaceae var. heleocharo- 
Table 4: vegetations of Centaurium vulgare latifolium with halophytes

No. of column

No. of analysis

Area in $\mathrm{m}^{2}$

Total cover in \%

differential species combination

Centaurium vulgare latifolium

idem rosettes

Centaurium vulgare vulgare

Leontodon nudicaulis

Bryum angustirete

hygrosere

1. Nanocyperion-group

Sagina procumbens

Centunculus minimus

Cicendia filiformis

Radiola linoides

Carex serotina pulchella

Juncus bufonius

2.

Eleocharis quinqueflora

Campylium polygamum

3.

Juncus articulatus

Empetrum nigrum

Cephaloziella hampeana

Pellia endiviaefolia

Carex flacca

Salix repens

Eleocharis palustris sspp.

Nostoc sp.

halosere

Juncus gerardii

Festuca rubra litoralis

Euphrasia odontites

Agrostis stolonifera salina

Glaux maritima

Triglochin maritima

Carex distans vikingensis

Plantago maritima

Centaurium pulchellum

Scirpus rufus

Plantago coronopus

mesosere

Trifolium repens

Leontodon autumnalis

Potentilla anserina

Holcus lanatus

Brachythecium albicans

Poa pratensis

Linum catharticum

Lotus corniculatus corniculatus

$\begin{array}{cccccccc}1 & 2 & 3 & 4 & 5 & 6 & 7 & 8 \\ 01 & 02 & 05 & 06 & 07 & 48 & 03 & 04 \\ 1 / 4 & 1 / 4 & 2 & 2 & 2 & 4 & 2 & 2 \\ 70 & 70 & 90 & 95 & 70 & 95 & 95 & 100\end{array}$

$\begin{array}{llllllll}1 & + & 1 & 1 & + & 2 & 2 & 1 \\ - & - & 2 & 1 & 1 & 1 & + & 1 \\ 1 & + & - & \frac{1}{1} & - & + & + & 1 \\ - & - & - & 1 & \pm & + & + & + \\ \end{array}$

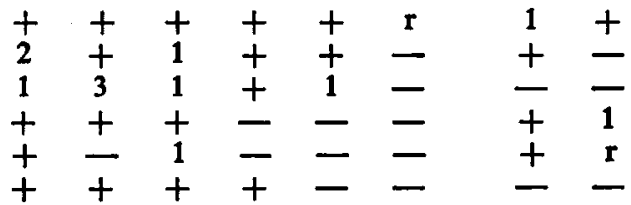

$\begin{array}{llllll}2 & 2 & + & 1 & 2 & -\end{array}$

$2 \pm \pm 1+1 \quad \frac{1}{r}-$

$11++-1-$

$+ \pm \pm \pm= \pm \bar{t}$

$\div-\bar{r}=\frac{r}{r}$

$\overline{ \pm}= \pm \pm \bar{t}=$

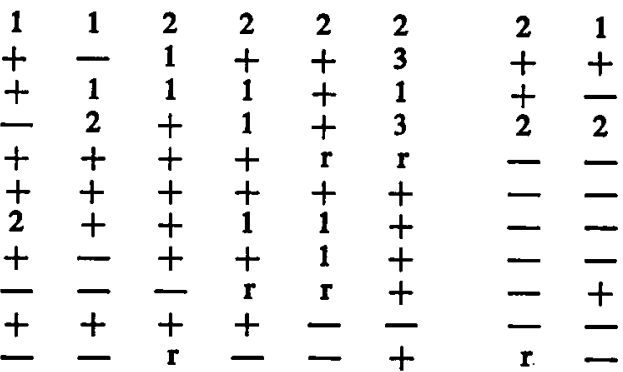

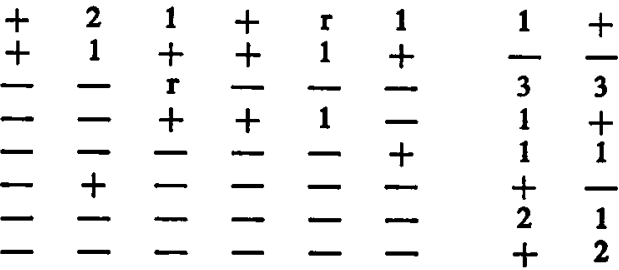

All analyses in July 1964, except no. 48 on $3-8-' 62$ 
sum described by Diemont et al. (1940) for the Westfrisian Islands. This variant was considered to be typical for disturbed places along the coast. In a later publication WESTHOFF (1947 b) mentioned the subassociation of Trifolium fragiferum, typical for the transition from hygrosere to halosere. With reference to these data in the literature the vegetation of the columns 1 - 5 may be classed in the Cicendietum. The relation of the vegetations of columns 6, 7 and 8 to the Nanocyperion is possibly not close enough to class them in this phytosociological unit. Anyway, it is clear that the community or communities of Table 4 cannot be considered as specimens of the Centaurio-Saginetum. The second important feature of the CentaurioSaginetum - the combination of xerosere and hygrosere (or halosere) is absent, as is the indicator species Sagina nodosa.

\subsubsection{The presence of species in the Centaurieto-Saginetum}

In order to get a good survey, data on presence and abundance of species occurring in the Centaurio-Saginetum and related communities were assembled in the Tables 5 A-B-C. All analyses available were used (the numbers correspond to the column numbers):

1. 15 analyses of the Sagino-Cochlearietum on the Boschplaat,

2. the wet saline variant of the subass. of Sagina maritima on the Boschplaat; Table 2 columns 26-50,

3. idem dry variant; Table 2 column 1-25,

4. analyses of the subass. of Sagina maritima made on the "Oosterstrand" (Westfrisian island of Schiermonnikoog),

5. wet variant of the Centaurio-Saginetum; 21 analyses of the Noordvaarder,

6. idem; 24 analyses made in the area "km marks 6-8",

7. dry variant of the Centaurio-Saginetum; 17 analyses also made in the area "km marks 6-8",

8. idem; 25 analyses of the Noordvaarder,

9. Centaurio-Saginetum; the 17 analyses shown in Table 1,

10. terminal stage of the Centaurio-Saginetum; 12 analyses of the Noordvaarder,

11. secondary Centaurio-Saginetum; Table 3,

12. community of Centaurium latifolium; Table 4. 
Presence and most frequent total estimate (German: häufigste Artmächtigkeit) of each species were determined and the figures were placed in tables according to the method of PASSARge (1964). In this system the symbols have the following values:

\begin{tabular}{cccc} 
first figure & $=$ presence & \multicolumn{2}{c}{ second figure $=$} \\
0 & $<10 \%$ & 0 & most frequent total estimate \\
1 & $10-20 \%$ & 1 & 1 \\
2 & $21-40 \%$ & 2 & 2 etc. \\
3 & $41-60 \%$ & & \\
4 & $61-80 \%$ & & \\
5 & $81-100 \%$ & &
\end{tabular}

The most frequent total estimate is the symbol for total estimate a certain species gets most often in a certain table. The most frequent total estimate is generally the same as the "average" total estimate or the intermediate between the two extreme values, which are often used in presence tables. The presence figures of the columns 4 and 11 designate the absolute presence. To shorten the Tables 5 the following unimportant species were omitted:

species only occurring in 1 or 2 columns with highest presence 1 , species only occurring in a few columns with highest presence 0 .

The sequence of the columns except no. 12 was based on the decreasing number of halophytes in the first place.

The differential species combination

All species of this group attain high values of presence except in the columns 1 and 11 i.e. in the Sagino-Cochlearietum and the secondary Centaurio-Saginetum. Centaurium vulgare is a very faithful species. Apart from its own community it only occurs in a few communities of the upper salt marsh with reduced abundance or vitality as in the Sagino-Cochlearietum.

The halosere

The Sagino-Cochlearietum and the wet saline variant of the CentaurioSaginetum subass. of Sagina maritima have many halophytes in common. However, most of them have a greater presence as well as a higher abundance or coverage in the former community. This difference appears most clearly from the first subgroup of halosere-species. Amblystegium serpens ssp. juratzkanum (Schimp.) Dix and Pottia heimii are faithful species of the Sagino-Cochlearietum according to WeSthoff et al. (1961). The halophytes Salicornia europaea and Cochlearia anglica are typical for the lower salt marsh. These four species can be considered as differential species between the Sagino-Cochlearietum and the Centaurio-Saginetum on the Boschplaat. Apart from the Sagino-Cochlearietum the species of the second subgroup of halophytes only occur in the subass. of Sagina maritima and in 
Table 5A: presence and most frequent total estimate of species in communities

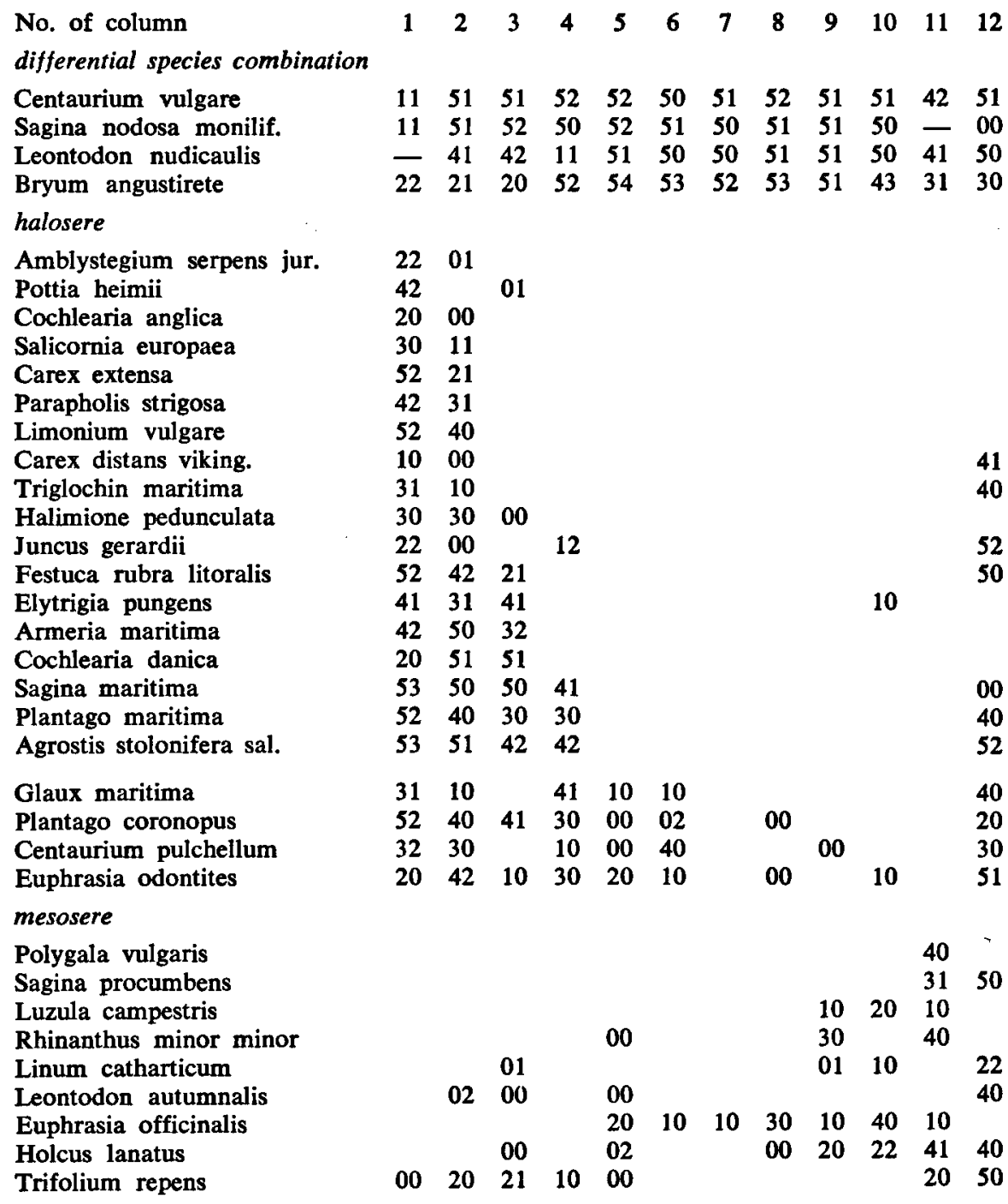


the community of Centaurium latifolium. Carex extensa and the other species of this subgroup are differentiating between the more saline and the less saline forms of the Centaurium-community. The species of the last subgroup, however, are also found in the Centaurio-Saginetum of dune slacks. Apparently they can grow under oligohaline circumstances.

\section{The mesosere}

The contribution of mesophytic plants to the floristic composition of the Centaurio-Saginetum is small. This phenomenon is a consequence of the pioneer nature of this association. As appears from Table 5A the mesosere is particularly present in the older stages of the Centaurio-Saginetum.

The xerosere and the hygrosere

The Centaurio-Saginetum principally consists of two well-balanced groups of plants: the xerophytes and the hygrophytes. These two opposite groups can be compared in the Tables $5 \mathrm{~B}$ and $\mathrm{C}$ which were subdivided in differential groups as far as possible.

Ceratodon purpureus typifies the terminal stage of the Centaurio-Saginetum which was studied on the Noordvaarder, where it occurs in the inner zones. In the course of the dune succession the difference between dune top and dune slack seems to decrease. Differences in elevation may decrease by wind erosion. The increasing content of organic matter levels out the original variation in water content of the soil. Both habitats are gradually covered by closed vegetations and mesophytic plants and deeply rooting plants establish themselves throughout the dune area. During this process the wellmarked transition zone occupied by the Centaurio-Saginetum disappears and so does the community itself. The last or terminal stage of the CentaurioSaginetum is among other things characterized by a well-developed moss layer as an exponent of which Ceratodon purpureus was chosen.

The Viola-group, typical for the Centaurio-Saginetum surrounded by old xerosere-communities, was already treated. Senecio jacobaea and Phleum arenarium occur mainly in drier stands of the typical Centaurio-Saginetum with low presence and abundance. The Camptothecium-group appears to be absent in optimal stages. The last group of the xerosere comprises species which are more or less common plants in the Centaurio-Saginetum. They are almost absent in the wetter communities Sagino-Cochlearietum and Cicendietum filiformis.

The Juncus-group of the hygrosere is more or less present in the distinct forms of the Centaurio-Saginetum. The Salix-group, however, only occurs in the non-saline forms of the Centaurio-Saginetum. Halosere and hygrosere are vicarious in this community. Agrostis salina is substituted by $A$ grostis arenaria in dune slacks with low salinity. The wet variants of the Noord- 
Table SB: presence and most frequent total estimate of species in communities

No. of column

xerosere

Ceratodon purpureus

Viola tricolor curtisii

Jasione montana

Rumex acetosella

Corynephorus canescens

Hypochaeris radicata

Cerastium holosteoides

Senecio jacobaea

Phleum arenarium

Camptothecium lutescens

Cladonia sp.

Brachythecium albicans

Lotus corniculatus corn.

Elytrigia juncea

Poa pratensis

Cerastium semidecandrum

Aira praecox

Ammophila arenaria

Anthyllis vulneraria

Sedum acre

Carex arenaria

Hippophaë rhamnoides

Hieracium umbellatum

Cerastium atrovirens

Sonchus arvensis

Taraxacum sp.

Festuca rubra arenaria $\begin{array}{llllllllllll}1 & 2 & 3 & 4 & 5 & 6 & 7 & 8 & 9 & 10 & 11 & 12\end{array}$

31

$\begin{array}{lllllllll} & & & & 00 & 20 & 10 & & \\ & & & & 00 & 20 & 30 & 11 & \\ & & & & & 11 & 10 & 10 & \\ 00 & 00 & & & 20 & 21 & 11 & & \\ & 30 & 00 & 10 & 40 & & 40 & 31 & \\ & 10 & 00 & & 10 & & 00 & 20 & 00 \\ & & & & & & & & \\ & 00 & 00 & 10 & 10 & & & & \\ & 00 & & 10 & 30 & 20 & & & \end{array}$

$22 \quad 21$

$10 \quad 32$

0121

$01 \quad 31$

$\begin{array}{llll}00 & 11 & 21 & 21\end{array}$

$\begin{array}{lllllllllll}01 & 10 & 10 & & 10 & & 50 & 20 & 21 & 31 & 21\end{array}$

$\begin{array}{lllllll}00 & 21 & 01 & 30 & 20 & 21 & 20\end{array}$

$\begin{array}{llllllll}20 & 10 & 30 & 41 & 21 & 20 & 00\end{array}$

$\begin{array}{lllllll}03 & 20 & 20 & 40 & 10 & 20 & 30\end{array}$

$\begin{array}{llllllll}00 & 21 & 42 & 20 & 40 & 10 & 42 & 00\end{array}$

$\begin{array}{llllllll}20 & 20 & 30 & 00 & 30 & 30 & 50 & 11\end{array}$

$\begin{array}{lllllllll}01 & 41 & 52 & 20 & 00 & & 10 & 11 & 01\end{array}$

$\begin{array}{lllllllll}01 & 11 & 10 & 20 & 20 & 01 & 50 & 50 & 20\end{array}$

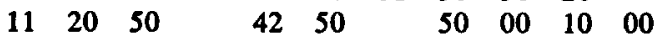

$\begin{array}{lllllllll}00 & 20 & 20 & 10 & 30 & 20 & 30 & 50 & 10\end{array}$

$\begin{array}{lllllllll}12 & 51 & 51 & 50 & 30 & 20 & 30 & 31 & 31\end{array}$

$\begin{array}{lllllllll}10 & 10 & 30 & 50 & 40 & 30 & 50 & 30 & 10\end{array}$

$\begin{array}{lllllllllll}01 & 01 & 10 & 40 & 10 & 10 & 40 & 10 & 30 & 20\end{array}$

$\begin{array}{lllllllllll}02 & 52 & 53 & 41 & 21 & 20 & 40 & 10 & 52 & 52 & 30\end{array}$ 
Table 5C: presence and most frequent total estimate of species in communities

No. of column

hygrosere

Juncus artic./alpinus

Calamagrostis epigejos

Nostoc sp.

Parnassia palustris

Salix repens

Carex flacca

Agrostis stolonifera aren.

Carex serotina pulch.

Juncus bufonius

Phragmites communis

Epilobium palustre

Pyrola rotundifolia

Orchis incarnata

Empetrum nigrum

Cephaloziella hampeana

Riccardia pinguis

Carex trinervis

Didymodon tophaceus

Calluna vulgaris

Radiola linoides

Centunculus minimus

Cicendia filiformis

Eleocharis quinqueflora

Campylium polygamum

$\begin{array}{llllllllllll}1 & 2 & 3 & 4 & 5 & 6 & 7 & 8 & 9 & 10 & 11 & 12 \\ & & & & & & & & & & & \\ 12 & 10 & & & 51 & 40 & 20 & 20 & 31 & 20 & 40 & 20 \\ & 01 & 01 & & 00 & 10 & & & 20 & & 20 & 00 \\ 22 & 21 & 11 & & 03 & & & & 21 & & & 20 \\ 00 & 01 & & & & 00 & & & 10 & 10 & & \\ & & & & & & & & & & & \\ & & & & 20 & 51 & 10 & & 40 & 20 & 41 & 20 \\ & 01 & & & & 10 & & & 21 & 00 & 20 & 20 \\ & & & 51 & 51 & 52 & 31 & 31 & 21 & & \\ & & & 00 & 20 & & & 21 & & 10 & 30 \\ & & & 20 & & & 00 & 10 & & 40 & 30 \\ & & & & 10 & 20 & & & & 10 & & \end{array}$

20

$00 \quad 20$

00

00

00

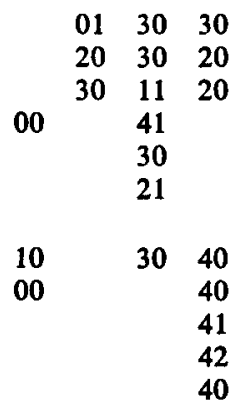


vaarder and the area "km coast-marks 6-8" are weakly typified by respectively Epilobium palustre and the combination of Pyrola rotundifolia and Orchis incarnata. On the Noordvaarder, especially in its northern part, many hygrophytes are found. The occurrence of Pyrola and Orchis may be due to the specific situation in the area between the $\mathrm{km}$ coast-marks 6 and 8 . Dune formation goes together with dune erosion. Slacks with Salix repensvegetations are covered by sand and thus a new environment for Centaurium vulgare originates, in which elements of the original vegetation maintain themselves: Orchis, Pyrola, Salix. About the last two groups nothing can be added to the facts already known: Empetrum etc. mark the secondary or old Centaurium-community and Radiola etc. designate the Cicendietum of the Groene Strand.

As in the case of the Centaurio-Saginetum subass. of Sagina maritima on the Boschplaat, it was possible to divide the rather great number of analyses of the Noordvaarder and the area "km marks 6-8" into a "dry" and a "wet" group. The former group represents a dry variant of the Centauriumcommunity (columns 7 and 8), the latter group a wet variant, characterized by more species of hygrosere, halosere and mesosere (columns 5 and 6). The Centaurio-Saginetum was described (section 2.3.1) as a plant community characterized by a few indicator species and by the combination of xerophytes and hygrophytes. In an average stand of the community there is an equilibrium between xerosere and hygrosere. In extreme specimens of the two variants this equilibrium is shifted to one extreme or the other, but there exists no essential or qualitative difference in the structure of the community. For this reason the wet and dry forms of the community of Centaurium vulgare are regarded and treated as variants and not as subassociations. In earlier descriptions of the Centaurio-Saginetum (section 2.2) the subassociations thrincietosum and samoletosum were distinguished. The former subassociation was described for dry almost desalinated environments e.g. young slacks and their slopes and the latter subassociation for more saline and wetter spots on the salt marsh. In the description of these subassociations two environmental factors were combined: dry and desalinated on the one hand and wet and saline on the other hand. However, Centaurium vulgare occurs also on wet and desalinated slack bottoms as well as in dry and rather saline habitats of the salt marsh. On the preceding pages a description of these environments was given. It was for this reason that the author substituted the old division of the association by a new one: the ass. Centaurio-Saginetum consists of a typical subassociation - defined in the same way as the association itself - and the saline subassociation of Sagina maritima, differentiated by the occurrence of halophytes. Both subassociations can be divided into a dry and a wet variant, if necessary.

During the investigations on Terschelling Samolus valerandi was never found in the plant community of Centaurium vulgare. Therefore this species 
could not be used in the description of the association. It was observed only in the wet variant in a slack on Voorne.

In the Centaurio-Saginetum many species do not attain an optimal development and vitality. The environment is too wet for xerophytes and too dry for hygrophytes. Consequently, these plants only attain a low dominance (e.g. Anthyllis vulneraria), sociability (e.g. Ammophila arenaria) or density (e.g. Cerastium semidecandrum). Many species only occurred in a few analyses. Thus the symbols 0 and 1 indicating a low presence and total estimate occur very often in the tables. The number of species per analysis is low, while the total number of species in the Centaurio-Saginetum as a whole is high. The average number of species in the typical CentaurioSaginetum is 13. The community of Centaurium vulgare resembles other pioneer communities with regard to this low average number of species, but it distinguishes itself by its varying composition.

Finally, a few words may be said about the problem of classification. As there is no sufficient affinity to the Nanocyperion it is undesirable to class the Centaurio-Saginetum in this alliance. The presence, abundance and vitality of real Nanocyperion species in the Centaurio-Saginetum is almost nil. Carex serotina pulchella and Juncus bufonius, which were considered as characteristic species of this alliance, have the same relation to the community of Centaurium vulgare as other hygrosere species. Based on the ecology it is also possible to define differences between the CentaurioSaginetum and the Nanocyperion. Communities of the Nanocyperion-alliance occur in places which are wetter, generally as a consequence of a higher phreatic level. The contact-communities may belong to the order Bidentetalia. Often the Nanocyperion-communities are more or less anthropogeneous. Most species are therophytes and the vegetations are often ephemeral. Moreover, it is quite impossible to class the community of Centaurium vulgare in syntaxa of the hygrosere or the xerosere simply because of the equal affinity to both seres. The Centaurio-Saginetum forms the transition between these two formations in the dune-area. The only solution to this problem seems to be to class the Centaurio-Saginetum in new categories of their own: Centaurion vulgaris, Centaurietalia vulgaris and Centaurietea. In the absence of other possible associations which should be classed in these units, these new syntaxa should be characterized in the same way and with the same species as the Centaurio-Saginetum. To solve the classification problem of the community of Centaurium vulgare the author followed the example given by TüXeN and WesthofF (1963) in their treatment of the Sagino-Cochlearietum.

In a discussion on the classification problem of the Centaurio-Saginetum, WeSTHOFF (1966, pers. comm.) suggested to link the community of Centaurium vulgare to the class Saginetea. This suggestion was based on the ecological similarity. Such a relation should be clearly distinguished from a 
classification in the Saginetea. The Centaurio-Saginetum should be regarded as an "appendix-community" of the class Saginetea. This procedure would mean the introduction of non-floristic criteria in the phytosociological system.

\subsection{The distribution of plant communities with Centaurium vulgare}

In the Netherlands the Centaurio-Saginetum occurs on open, moist, somewhat saline sandy dune soils. Nowadays this environment is almost restricted to the Westfrisian Islands in the north and the islands in the SW.region, as a consequence of the lowering of the water table by waterworks in the dunes of the mainland. (See the distribution of the species.) Apart from the literature already mentioned we refer to three Dutch papers on the distribution of the Centaurio-Saginetum. Schroevers (1951) described the Centaurio-Saginetum occurring on the slopes of the slack "Buitengeulvallei" in the southwestern part of Texel. In a report on the vegetation of an area on the island of Schiermonnikoog VAN DER ToORN (1959) described also the Centaurio-Saginetum. In his opinion there were three forms of the CentaurioSaginetum in this region: the typical one, a facies with Hippophä and a variant which agrees with the subass. of Sagina maritima. Our own observations on Schiermonnikoog agree with these results. In a report on the vegetation of the island of Schouwen, a vegetation of the Centaurio-Saginetum was recorded by WeSTHOFF et al. (1960).

In several papers the occurrence of the Centaurio-Saginetum south of the Netherlands was treated. Duvigneaud (1947) described the dune region between la Panne and Dunkerque in Belgium; on spots where sods were cut in dune slacks, he found a wet variant of the Centaurio-Saginetum with the following characteristic species: Centaurium vulgare, Sagina nodosa, Bryum angustirete, Blackstonia perfoliata and Gnaphalium luteo-album. A somewhat different form of the Centaurio-Saginetum occurred in slacks, where the original vegetation of Campylium stellatum, Salix repens and Carex trinervis was covered with blowing sand. LAMBINON (1956) investigated the adjacent coastal area between la Panne and Coxyde. He found only fragments of the Centaurio-Saginetum but enough to distinguish a dry and a wet variant. In his study on the taxonomy of Centaurium vulgare RoBIJNS (1964) stated that the Centaurio-Saginetum occurred in the coastal region of Belgium in an environment as described in the present publication. BEEFTINK (1964) observed a vegetation of Centaurium vulgare with Hippophä and a number of hygrophytes in a secondary dune valley near the village of Hardelot-Plage in NW. France (district Pas-de-Calais).

The following data on the plant community of Centaurium vulgare in Great-Britain can be mentioned. In a survey of the plant communities and their ecology in the dune region Newborough Warren (Anglesey, NW.Wales) 
RANWELL (1960) described the floristic composition and environmental factors of a community which shows a great resemblance to the CentaurioSaginetum treated in the present publication. Ranwell himself did not use this name. WiLlis et al. (1959) gave a similar description of another dune region called Braunton Burrows (Devon). One of the plant communities described was composed of Sagina nodosa and maritima, Leontodon nudicaulis, Bryum angustirete, Centunculus minimus and other species. This plant community resembles the Centaurio-Saginetum with respect to floristic composition and habitat. However, the main species Centaurium vulgare itself was absent. Because there are suitable habitats for Centaurium vulgare on Braunton-Burrows - at least as far as we can conclude from the abovementioned paper - the absence of the species here and probably elsewhere along the south and east coasts of England is a plantgeographical problem. Finally, we refer to a travel report of Van Der MaArel and Van Der MaARel-Versluys (1963), who observed the Centaurio-Saginetum in two English dune areas, namely Braunton-Burrows and Sandskale Hawk (Lancashire).

The present author did not succeed in finding data on the occurrence of the typical Centaurio-Saginetum in the northern part of the range of Centaurium vulgare. In his survey of the plant communities of NW. Germany Tüxen (1955) mentioned the association of Centaurium vulgare and Gentiana uliginosa classed in the Nanocyperion. This combination of species was described by Braun-Blanquet and De Leeuw (1936) (see section 2.2). All other data in the literature refer to the occurrence of Centaurium vulgare as a constituent of salt vegetations. According to the flora of CHRISTIANSEN (1953) covering Schleswig-Holstein Centaurium vulgare is a faithful species of the Armerion. TüXen et al. (1957) found Centaurium vulgare in the Sagino-Cochlearietum on the island of Neuwerk in the mouth of the river Elbe. On the south-west coast of Sweden Centaurium vulgare occurs in the Sagino-Cochlearietum too and in a community dominated by Juncus gerardii (GILLNER 1960). In the latter community also Sagina nodosa was found. In the thorough survey of PASSARge (1964) which gives all plant communities of the northeastern German lowland Centaurium vulgare is only mentioned in the communities Blysmetum rufi and Caricetum extensae belonging to the Armerion. 


\section{Addenda to Table 1:}

Column 2: Myosotis ramosissima + , Oenothera cf. muricata $r$, Luzula campestris $r$, Centaurium pulchellum + , Polytrichum sp. +

4: Veronica officinalis $r$

5: Brachythecium albicans $r$

6: Viola canina $r$, Linum catharticum 1

7: Potentila anserina $r$

13: Honckenya peploides $r$

14: Carex trinervis $r$

15 : Mentha aquatica $\mathbf{r}$

16: Centunculus minimus + , Pyrola rotundifolia + , Ranunculus acer $r$.

\section{Addenda to Table 2:}

Cladonia cf. furcata in columns:

$$
2(2)-8(2)-13(3)-21(t)-23(2)-24(3)-37(t)
$$

Cladonia cf. glauca in columns:

$$
17(2)-22(t)-36(t)-39(t)-41(3)
$$

Column 3: Cladonia rangiformis 2, C. pyxidata 1

6: Peltigera sp. 2

9: Peltigera sp. r, Cladonia pyxidata 1, C. foliacea alcicornis +

11: Holcus lanatus + , Potentilla anserina $r$, Vicia lathyroides $r$

25 : Oenothera muricata $r$

29: Atriplex littoralis +

41: Carex flacca 1, Schoenus nigricans 1

46: Juncus gerardii + , Amblystegium serpens juratzkanum 1

49: Carex distans + .

Addenda to Table 3:

Column 11: Erica tetralix + , Pedicularis palustris + , Riccardia pinguis 1, Luzula campestris +

08 : Anthyllis vulneraria 1, Jasione montana 1, Hieracium umbellatum r, Rumex acetosella $\mathbf{r}$

09 : Euphrasia officinalis + , Cirsium palustre r, Hippophaë rhamnoides $\mathbf{r}$, Trifolium arvense + , Carex serotina pulchella + , Vicia lathyroides $r$, Ranunculus acris $\mathbf{r}$.

\section{Addenda to Table 4:}

Column 4: Lycopus europaeus r, Anthoxanthum odoratum +

5 : Hippophaë rhamnoides $\mathbf{r}$

6: Triglochin palustre 1, Sagina maritima $r$

7: Cerastium holosteoides + , Plantago lanceolata $r$, Calamagrostis epigejos + , Agrostis tenuis r, Sagina nodosa +

8 : Sieglingia decumbens + , Cerastium semicandrum $r$. 
Chapter 3:

THE GERMINATION AND THE FIRST STAGES OF THE LIFE-CYCLE

\subsection{Introduction}

The plants of Centaurium vulgare produce ripe fruits in the autumn of their second season. From observations in 1961 and 1966 it appeared that seeds were dispersed from the middle of September onward. Most seeds seem to fall in the immediate vicinity of the parent plants. Seeds of Centaurium vulgare do not show dormancy. In experiments carried out with newly formed seed in September 1961 the germination was 94\% after 8 days of incubation. In his life form system of hapaxants BAKKER (1966) classed Centaurium vulgare in group $\mathrm{C} 1$ i.e. biennials without dormancy. Although the seeds of Centaurium vulgare do not show dormancy and might germinate immediately upon dispersal, a very small quantity of them actually germinates in autumn. Most of them hibernate, germinating in the following spring.

During the investigations on Terschelling extensive observations were made on the occurrence of seedlings in different habitats of Centaurium vulgare. Every year the first seedlings and the greatest number of them were observed in the last week of April and the first half of May. These more or less incidental observations rendered no answer to the question whether all specimens of Centaurium vulgare germinated in the same spring-period. Young rosettes, found in the stands of the Centaurio-Saginetum after spring, might have originated from recently germinated seed but they might also be "older" juvenile plants with a retarded development.

Therefore the author studied the germination of Centaurium vulgare in an area of restricted size in a dune slack on Voorne. The emergence of seedlings was closely observed on a number of field plots and the influence of temperature and soil moisture was investigated. For the methods of measurement of the ground water level and soil moisture the reader is referred to the chapters 4 and 5. Although the results of the investigations on Voorne can on the whole be applied to the situation of Centaurium vulgare on Terschelling, it is possible that the special circumstances of the site on Voorne influenced these results in some minor respects.

One of the main characteristics of the slack on Voorne in which the investigations in 1965 and 1966 were carried out, is a very long inundation period. Sometimes even during the summer great parts of it are flooded. As a consequence of this a luxurious growth of algae occurs. As was mentioned in chapter 1 only the variety iberoides occurs on the island of Voorne. On the site of investigation naturally occurring plants of var. iberoides and specimens of the var. vulgare, which were sown, occurred. 
Because plants of both varieties appeared to behave in the same way during the investigations, no distinction will be made in this chapter between the two varieties.

\subsection{The influence of the temperature}

In the present study the influence of the temperature was investigated in two ways. First the potential germination under different temperature conditions was investigated in the laboratory. The following temperature regimes were used for germination experiments: $30^{\circ}-24^{\circ}-13^{\circ}-4^{\circ}-25^{\circ} / 15^{\circ}-$ $30^{\circ} / 5^{\circ}$ C. All experiments lasted sixty days except the $30^{\circ}$-experiment ending after eight days. Twelve hours light alternated with twelve hours darkness. In the dark period the lower temperature was given. In the germination experiments in the laboratory seeds of different populations belonging to the varieties vulgare and iberoides from Terschelling, Voorne and Goeree were used. (The author is much indebted to Mr. G. de Vos who carried out most of the experiments in the Plant Ecology Laboratory at Groningen.) Put briefly, the following results were obtained from the experiments:

$4^{\circ} \mathrm{C}$. no germination

$13^{\circ} \mathrm{C}$. low total germination and low germination rate

$24^{\circ}$ and $25^{\circ} / 15^{\circ} \mathrm{C}$. after 15 days of incubation $80-100 \%$ germination

$30^{\circ} \mathrm{C}$. also a high germination percentage

$30^{\circ} / 5^{\circ} \mathrm{C}$. a much lower percentage.

The highest germination percentage was attained under rather high temperatures, e.g. $24^{\circ} \mathrm{C}$, while low temperatures retarded germination even when applied in combination with higher temperatures $\left(30^{\circ}\right.$ with $5^{\circ} \mathrm{C}$.). A simple experiment showed that germination in darkness is much slower and reaches a much lower percentage.

\section{Temperature measurements in the field}

Mercury thermometers were placed in the topmost soil layer of a Centaurio-Saginetum on a north slope. Maximal, minimal and actual temperatures were measured and recorded once in three days at $16.00 \mathrm{~h}$. These temperatures measurements of some periods are given in Table 6 .

In early spring the temperatures in the field are too low for germination. The mean maximal temperature is $13^{\circ} \mathrm{C}$. i.e. the temperature which was about minimal in the laboratory experiments. The mean minimal temperature of $4^{\circ} \mathrm{C}$. was too low for any germination to occur as the laboratory experiments had shown. In 1966 the first seedlings of Centaurium vulgare were observed on May 10th. In the preceding fortnight the temperatures reached a significantly higher level. The mean afternoon temperature 
Table 6: mean field temperatures on a Centaurium-site on Voorne

Period

15 March - 15 April 1966

20 April - 4 May 1966

26 April - 15 May 1965

20 September - 11 October 1965

idem, slack bottom $\max$.

at $16.00 \mathrm{~h}$

$\min$.

130

$19^{\circ}$

$20^{\circ}$

190

$9^{\circ}$
$15^{\circ}$
$15^{\circ}$
$13^{\circ}$
$17^{\circ}$

(All temperatures in centigrades)

exceeded the critical temperature of $13^{\circ} \mathrm{C}$. Almost the same temperatures were recorded for a corresponding period of 1965, when Centaurium vulgare germinated somewhat earlier (first seedlings on April 23rd). In this period of 1965 - 26 April - 15 May - mass germination took place.

In autumn after the dispersal of the newly formed seeds of Centaurium vulgare differences in temperature conditions occur as a consequence of the lower altitude of the sun. As in all other periods measurements were made on a north slope and on the bottom of the slack. On the north slope the temperature reached only rather low values and the afternoon temperature was on the average $13^{\circ} \mathrm{C}$. On the bottom of the slack higher temperatures were reached, but during shorter periods a day than in spring, also as a consequence of a lower altitude of the sun. In order to ascertain whether low temperatures, especially on northern slopes, restrict the germination in autumn, the following experiments were carried out. Petri-dishes with wet filter paper and seeds of Centaurium vulgare were put on the temperature sites of the north slope and of the slack-bottom. Moreover, some small field plots were prepared by stripping the ground of all juvenile plants of Centaurium vulgare and by seeding to Centaurium vulgare. In the Petridishes on the north slope and on the bottom of the slack percentages of germination were viz. $5 \%$ and $15 \%$ after 24 days. On the five field plots together only five new seedlings of Centaurium vulgare were observed. The germination after the shedding of seed in autumn is very low. First and foremost this must be the consequence of unfavourable temperature conditions. Also in the Petri-dishes, especially the one on the north slope, the germination was extraordinary low, in spite of a sufficient water supply.

During spring temperatures were measured in the soil surface of parts of the dune slack which were flooded with a shallow layer of water. The average maximal temperatures were as high as those recorded in Table 6, while the actual and minimal temperatures were still higher. The shallow layer of water acts as a heat reservoir during the night so that the temperature conditions in this environment are at least as favourable for germination as higher on the slope. Other circumstances prevent a rapid germination in this environment. 


\section{Conclusion}

Concluding it may be said that the moment of germination of Centaurium vulgare is regulated by the temperature conditions of the environment. The seed itself does not show a regulating mechanism like dormancy or a changing temperature response as in the case of a number of winter annuals (NEWMAN 1963). In the following section it will appear that the soil moisture of the environment influences the place of germination and the length of the germination period.

\subsection{The influence of the water factor}

\subsubsection{Methods and general remarks}

The appearance and early development of the seedlings was observed on eight field plots situated on the north slope of the slack. Fig. 3 shows the plot numbers, their relative height in $\mathrm{cm}$ above the level of the lowest plot and the numbers of juvenile Centaurium-plants counted. These were divided into three categories: seedlings (with only cotyls), small rosettes with two or more pairs of leaves, and yellow-coloured rosettes with reduced vitality. These three categories are designated by different blocks in Fig. 3. The size of these blocks i.e. the numbers of juvenile plants of Centaurium vulgare can be calculated by comparison with the standard block of 100 specimens in Fig. 3. For instance at the first count on plot 1, there were 2000 seedlings. In the season 1965 three or four counts were carried out on each plot. The dates can be found by projection of the left side of the blocks on the broken time-axis. The numbers of plants given are expressed as numbers of plants per $\mathrm{m}^{2}$. Some of the seedling-plots $(3,4,5$ and 7$)$ were $40 \times 40 \mathrm{~cm}^{2}$. To ensure germination all plots were seeded to Centaurium vulgare except 4 and 5. The plots 1 and 6 were broken up before the experiments.

The main purpose of the investigations on the plots was to obtain more exact information on the germination-period of Centaurium vulgare. During the investigations additional problems were studied. However, the conclusions on these secondary problems could not be as well founded as the author would have wished, owing to the limitations of the investigations. The number of plots was small and they were not quite equal in size, one of the difficulties of fieldwork being the finding of homogeneous sites. After the investigations were finished, it appeared that a representative plot for the uppermost part of the zone of Centaurium vulgare was lacking. (The upper subzone of the Centaurio-Saginetum as described in chapter 4, was not well-developed.) 
Fig. 3: numbers of juvenile plants of Centaurium vulgare on field plots

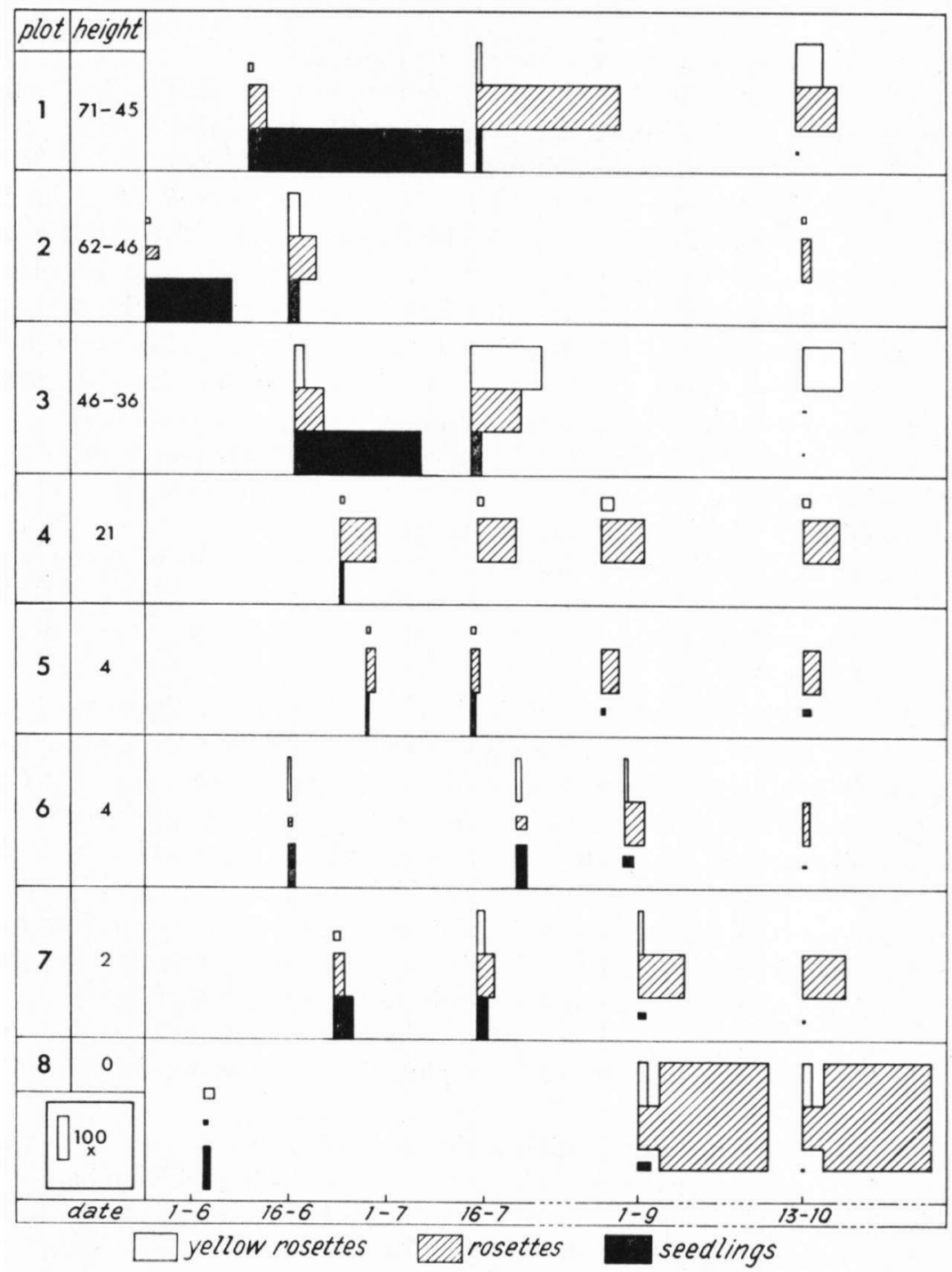




\subsubsection{The results of the experiments on field plots}

1. The first seedlings were observed towards the end of April. In May there was a mass germination especially on the plots 1,2 and 3 . At the first count of plants on these plots very high numbers were found. The plots 1 , 2 and 3, which were situated high on the slope of the slack, had a relatively short germination period. On a lower level e.g. in the plots 5 - 8 a number of seedlings appeared at a later date in the season. Besides, the total number of juvenile plants of Centaurium vulgare increased after May e.g. on plot 8 . The occurrence of seedlings apparently varied with the level of the plot.

2. At the last count - on October 13th - only very low numbers of true seedlings were found. On the high plots these had grown from the newly shed seed; on the lower plots these seedlings were partly present earlier in the season already and they had been counted also at one of the earlier dates. With regard to these low numbers in the autumn the reader is referred to the section on the influence of the temperature.

3. Apart from a difference in length of the germination period between the high and low plots there was a discrepancy in numbers of seedlings and juvenile plants. From the very beginning Centaurium vulgare had a heterodisperse distribution.

4. In Fig. 3 the development of the juvenile plants of Centaurium vulgare can be seen. By comparing the results of subsequent counts the development of the individuals from one category to the other can be seen. True seedlings changed into small rosettes and at the same time many specimens with reduced vitality occurred. There was a growth of the specimens and a change in the population density. On the high plots a rapid growth and an early reduction of density was visible. The development on the low plots was retarded. As a consequence of this difference in growth and mortality the variation in density on the field plots in October was rather low: 600-100 specimens. An exception was formed by plot 8 . Probably as a consequence of a highly developed micro-relief this plot yielded a much higher number of plants.

5. At the end of the observation period a number of 600 vital and yellow plants of Centaurium vulgare occurred on plot 1 . This high number is the result of the breaking-up of this plot before the investigations. In an earlier paper the author described the higher biomass of dug-up plots on the Boschplaat (FreIJSEN 1967). This phenomenon occurring on plot 1 was not repeated in plot 6 which had also been broken up beforehand. The wetness of this plot prevented a high production.

6. The plots 4 and 5 , which were not seeded, showed exactly the same general picture as the other plots. In the natural environment of Centaurium vulgare, in which the plots were situated, the density of seedlings was not influenced by sowing. 


\subsubsection{Discussion of the results obtained on the field plots}

1. Although the temperature conditions on a low level - also when inundated - are as good as on a high level and germination may occur in May, many seedlings appeared to emerge much later. As is shown in Fig. 4 plot 8 and the other low plots were inundated in May. In Fig. 5 the soil moisture contents of two soil layers of plots 2 and 8 are shown. Also after the disappearance of the surface water the soil of plot 8 and the other low plots was rather wet and contained $20 \%$ water. The surface layer contained still more water, which was held by organic material and algae. The surface water and the high soil moisture of the low plots had two effects. On the one hand a rapid germination of many seeds - when temperature conditions

Fig. 4: the level of the water table 1965 of the slack on Voorne

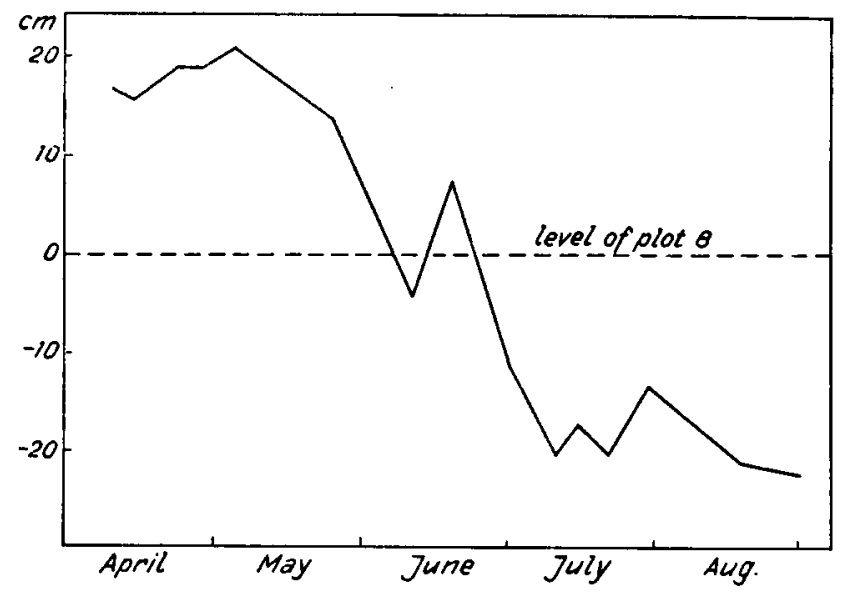

were favourable - was prevented. On the other hand germination was still possible in summer and still took place when on drier spots, for instance on plot 2, it was quite impossible for lack of water; see Fig. 5. In what way the germination of Centaurium vulgare was hindered by the excess of water is unknown. Although it is known that seeds need a minimal supply of water (HARPER and BENTON 1966), about the maximal amount of water tolerable for germination fewer data seem to be available. It seems possible that the algae play an important part in this respect in young dune slacks. Their extension and by it the immediate cover of the soil surface is dependent on the moisture conditions.

2. In section 3.2 it was mentioned that the temperatures in the autumn are not favourable for the germination of Centaurium vulgare. Moreover, the soil moisture in the environment of Centaurium vulgare is not high 
enough everywhere, e.g. on plot 2. In the following chapter it will be shown that in September the phreatic level is not high enough so that the capillary water cannot reach the surface. It seems strange that according to CLAPHAM et al. (1962) Centaurium littorale $(=$ vulgare) would germinate in autumn.

3. A difference in soil moisture was the main cause for the variation in density of juvenile plants on the plots. As has been mentioned above, too much water restricted the number of seedlings on the low plots. On the plots 1, 2 and 3 the seeds could germinate almost everywhere. This means that the number of suitable micro-sites was high. From other observations

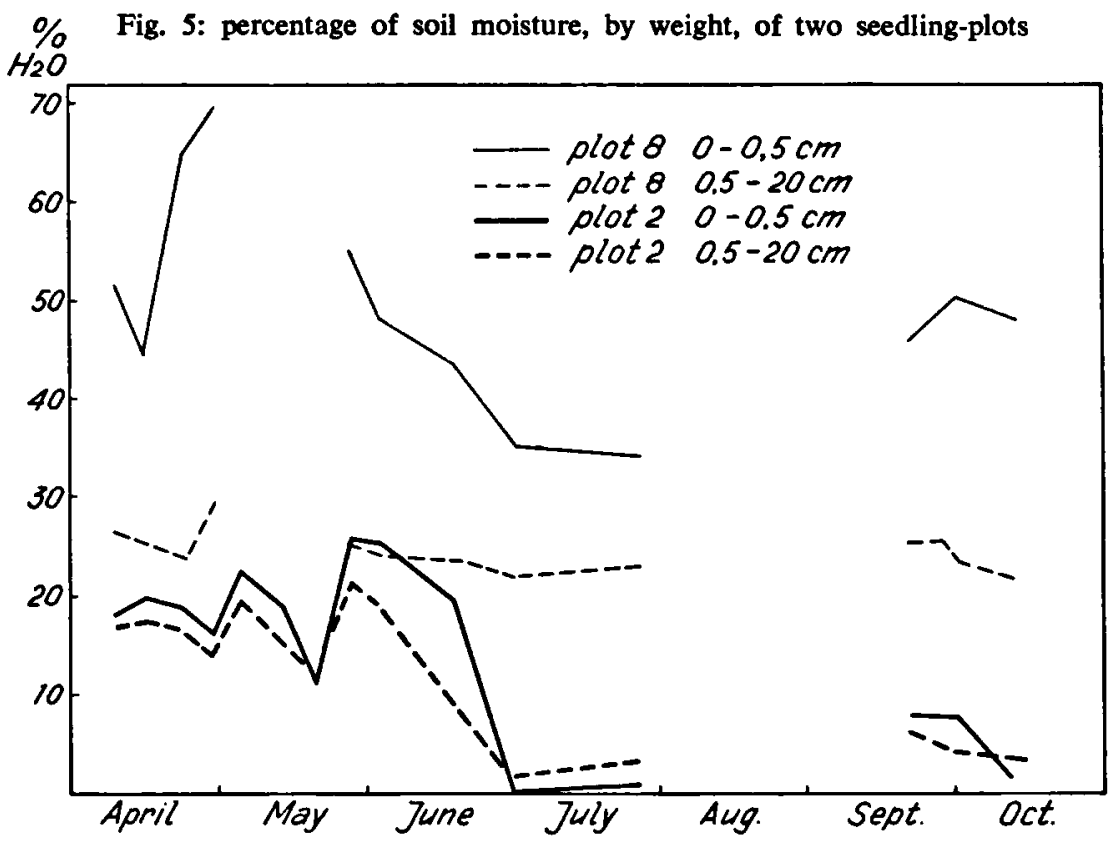

the conclusion was drawn that the density of seedlings decreases again above the level of these plots. On a high and dry level the number of micro-sites with sufficiently high moisture conditions decreases. In what way the water factor can become restrictive for the germination of seeds, can be understood from the experiments of HARPER et al. (1965) and HARPER and BENTON (1966). Seeds need a minimal supply of water for germination. This supply is determined by the water content of the substrate, the vapour pressure of the atmosphere and the properties of the seed as its size and the nature of the testa. The micro-relief of the soil surface plays an important part in this process. If these factors prevent a sufficient supply of water, no germination is possible. 
4. The rapid growth of Centaurium vulgare on the plots 1, 2 and 3 is of adaptational value. Also the roots of the plants on this higher and drier environment grow more rapidly. At the beginning of the dry summer season they have reached permanently waterholding soil layers. The soil of the lower plots contained much more water. For Centaurium-plants of this level the soil moisture is rather too high than too low. These maximal water conditions delay the development and growth of the plants. The life-cycle may last three years here.

It is of interest to compare Centaurium vulgare with the winter annuals. The life-cycle of these plants may also be regarded as an adaptation to the summer drought. Normally they only germinate in autumn, when the wet season starts. Sometimes they have an internal mechanism to prevent the germination of the newly shed seed under temporarily wetter weather conditions in summer. Germination in a wet spell would be dangerous, as the seedlings would not be able to survive a following dry period. RATCLiffe (1961) showed that the seeds of a number of these winter annuals need an after-ripening period. For the seeds of the annuals Teesdalia nudicaulis and Aira praecox the summer temperatures are unfavourable. Only in autumn the shifting temperature optimum for germination is the same as the field temperature (NEWMAN 1963).

In the dense populations of the rapidly growing plants on the higher plots the specimens of Centaurium vulgare interfered with each other. As a consequence of this interference (sensu HARPER 1961) many specimens died soon and the density of the plants decreased.

5. It appeared that sowing in a not too young population of Centaurium vulgare did not affect the density of the population. A great natural excess of seeds is present and the number of plants seems to be determined especially by the number of micro-sites in the habitat. Recently this was shown by LODGE (1964) for Cynosurus cristatus. Germination of this grass on seeded plots was lower than $50 \%$ of the "potential germination".

\subsection{Density of Centaurium vulgare in the second season}

When studying the development of Centaurium vulgare in the first summer, a few observations on second-year plants were taken. In two belt transects across the zonation - consisting of plots of $1 \mathrm{~m}^{2}$ size - counts of rosettes and adult plants were carried out, viz. on April 15th and August 6th 1965. The mean number of specimens of the two corresponding plots in the transects and the relative heights of the plots are given in Table 7.

While on the seedling-plots 600-100 juvenile plants occurred in autumn, in the two transects an average number of only 8 rosettes was found per $\mathbf{m}^{2}$ in spring. Apparently there is a severe mortality in winter. Finally only an average number of 3,5 specimens occurred on the plots of the two transects. 
In the second summer season a mortality of another 50\% happened. Especially on the low plots the decrease in number was very strong. Probably this mortality is caused exclusively by environmental factors. An exception in the overall picture was formed by the plots situated on heights between 38 and $21 \mathrm{~cm}$. On these plots the density in the spring and in the summer of the second season was significantly higher than in other parts of the two transects. The heterodisperse distribution of the plants of Centaurium vulgare in the transects is not exceptional. In the following chapter it will be shown that the zone of Centaurium vulgare always consists of three subzones characterized by varying density and size of plants.

Table 7: mortality of Centaurium vulgare in the second season

upper limit of plots in $\mathrm{cm}$ above seedling plot 8 ; mean number of rosettes on April 15th; mean number of adult plants on Aug. 6th;

$\begin{array}{rrr}48 & 4 & 3 \\ 45 & 12 & 8 \\ 38 & 252 & 104 \\ 28 & 40 & 18 \\ 21 & 18 & 6 \\ 20 & 13 & 6 \\ 20 & 7 & 3 \\ 19 & 4 & 1 \\ 18 & 11 & 7 \\ 18-20 & 7 & 4 \\ 20-17 & 8 & 3 \\ 17 & 12 & 5 \\ 17 & 7 & 2 \\ 14 & 2 & 0 \\ 13 & 2 & 1 \\ 12 & 3 & 0 \\ <12 & 10 & 0\end{array}$




\section{Chapter 4:}

\section{THE RELATIONS BETWEEN THE WATER TABLE AND THE CENTAURIETO-SAGINETUM}

\subsection{Introduction and method}

For the observation of the water table plastic ground water pipes were used. A description was given by GroenEwoud (1962). Gauging was carried out irregularly in 1963 and fortnighly in 1964. For reasons, which will become clear in this chapter, the depth of the soil water table was not expressed absolutely, but always in relation to the distribution pattern of Centaurium vulgare. For a better understanding of the following, some features of the community of Centaurium vulgare will be emphasized. In this context the Centaurio-Saginetum was regarded as a zone shifting on the slope of the dune slack. The upper limit of this zone - that is, the highest level on which plants of Centaurium vulgare occur - was briefly designated as upper limit and the Centaurium-plants in this borderline as upper plants or upper seedlings. Secondly, Centaurium vulgare is a biennial. The adult plants found in 1964 germinated in 1963 and had to be regarded as "generation 1963".

\subsection{Observations of the water table}

Fig. 6 gives a graphical representation of the water table in 1963 and 1964 measured in pipe 1 below the upper limit of the Centaurio-Saginetum of a small dune slack near the Biological Station. The depths of the phreatic level can be read off in centimetres below the upper limit of the Centauriumgeneration of 1963 as well as below that of 1964 .

The curve for 1963 can be divided into three parts: a wet spring period, a dry summer period and finally the autumn with an increase of the water level. The maximal depth — in July — amounted to $1 \mathrm{~m}$. The curve for 1964 shows great resemblance to that for 1963. The year 1964 was drier and in September the water table was still at a depth of about $1 \mathrm{~m}$. Only on August 1st a peak was measured, the result of a period with heavy rains. Both in 1963 and 1964 on May 1st the phreatic level was $55 \mathrm{~cm}$ below the highest level on which Centaurium-seedlings were found. Apparently the level on which the upper seedlings occurred, shifted with the ground water table, which was deeper in 1964 than in 1963.

Fig. 7 shows the fluctuations of the phreatic level in 1963 and 1964 in the soil of a terminal Centaurium-vegetation. The vegetation was almost 
Fig. 6: fluctuations of soil water table in the Centaurio-Saginetum

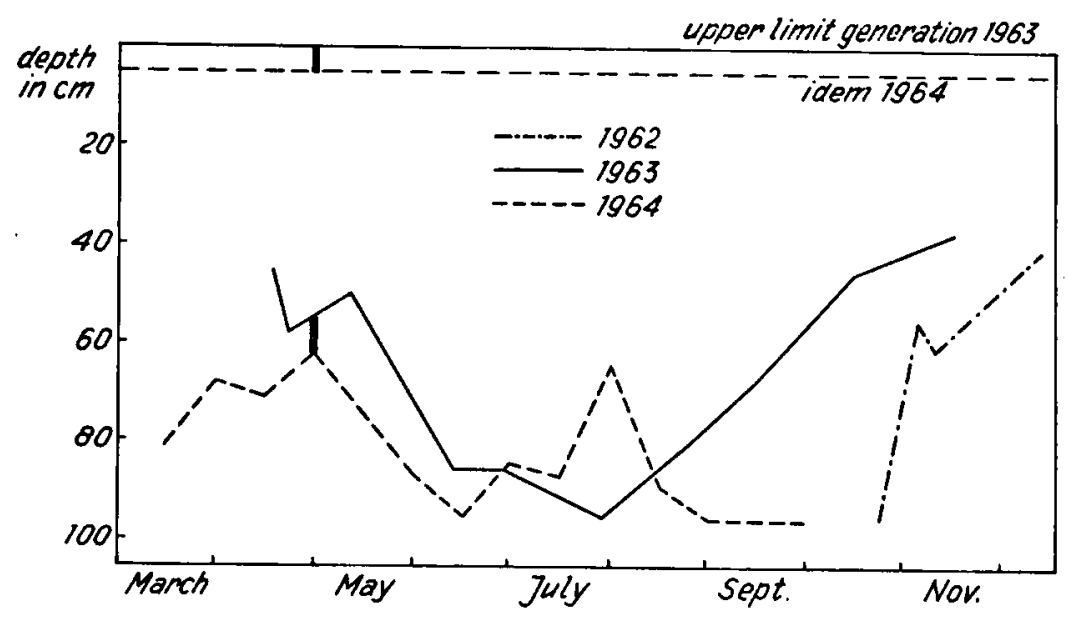

Fig. 7: fluctuations of soil water table in terminal stage of Centaurio-Saginetum

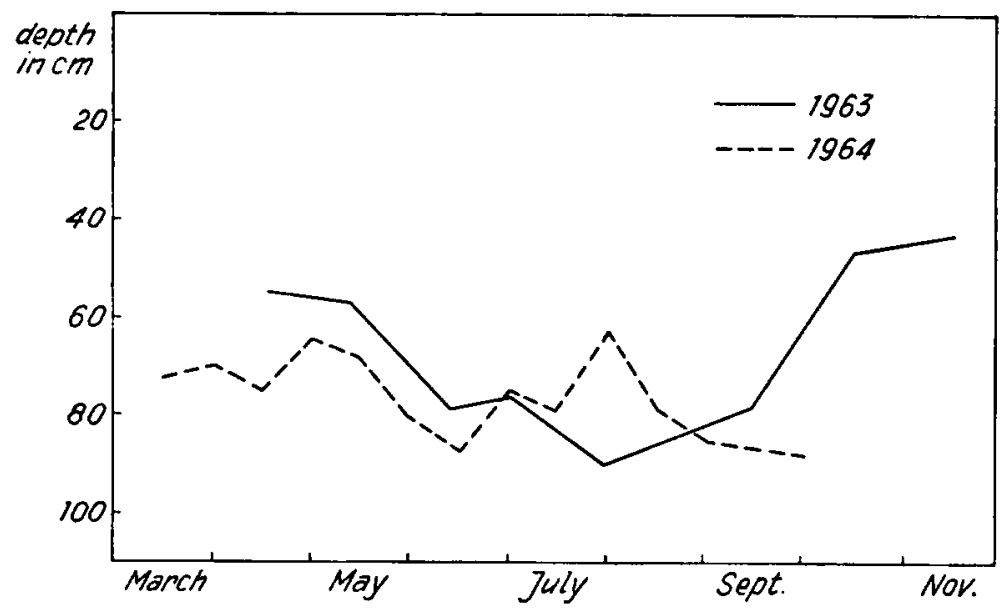

closed and it was composed of twentysix species of angiosperms, among which mesophytic plants were found. The general picture in Fig. 7 is more or less the same as in Fig. 6. During the optimal germination period of Centaurium vulgare the depth of the phreatic level is about $60 \mathrm{~cm}$. The curve for 1964 lies below that for 1963. The dry summer period started in May. The fluctuations of the water table on this site appeared to be smaller 
and the maximal depth was less. This is in agreement with the more mesophytic appearence of the vegetation.

Fig. 8 shows the depth and fluctuations of the phreatic level in 1964 and

Fig. 8: fluctuations of soil water table in the Centaurio-Saginetum, subass. of Sagina maritima

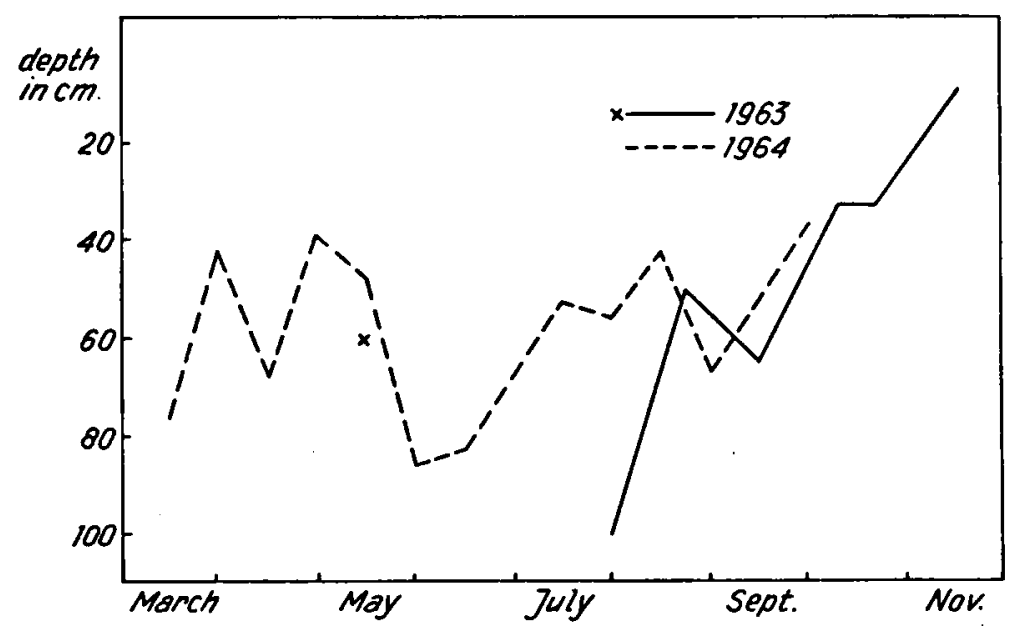

a part of 1963 on a site on the salt marsh Boschplaat, namely the lower limit of a vegetation belonging to the dry variant of the Centaurio-Saginetum subass. of Sagina maritima on a horseshoe dune. The curve for 1964 corresponds in some respects to the other curves mentioned above: high ground water in spring and autumn and a maximal depth of about $1 \mathrm{~m}$ after May. As a consequence of the influence of the sea-water movements on the water regime of the salt marsh there are some differences. The amplitude of the fluctuations is greater and besides - as was also clear from the records of another ground water pipe. (no. 25 1-a "Archief Grondwaterstanden") the soil water level increases much earlier in the summer season. Due to the lower (relative) level this site is wetter than both the other sites.

\subsection{Conclusions and comparison with data from the literature}

The fluctuations of the soil water table are a direct result of the weather conditions. Rainfall and evaporation are decisive factors. On the salt marsh the level of the sea water and its fluctuations also play an important part. According to TER HOEve (1951) the amplitude of the fluctuations in ground water level amounts to $1 \mathrm{~m}$ on the Westfrisian Islands. WeSTHOFF (1947 b) stated that May is the driest month and October the wettest one. Our observations on the three sites agree with these data. RaNwell (1959) 
described more or less similar seasonal fluctuations of the water table in the English dune area of Newborough Warren.

The maximal depth measured was $1 \mathrm{~m}$. It seems to be the lowest level occurring below the community of Centaurium vulgare during longer periods. This depth was measured on site 1 namely below the upper limit of the Centaurio-Saginetum. In general, Centaurium vulgare is restricted to places with a maximal depth of the ground water table of $1 \mathrm{~m}$. Exceptions are possible on favourable micro-sites, where secondary factors create a higher soil moisture, for instance on the top of horseshoe dunes. In that case the surrounding vegetation or the composition of the soil surface create more favourable moisture conditions. According to WESTHOFF (1947 b) the summer level of the water table was $20-50 \mathrm{~cm}$ below the surface in vegetations of the Centaurio-Saginetum subass. thrincietosum. This datum does not fit in the picture obtained through our observations.

In spring the phreatic level below the upper limit of the CentaurioSaginetum is at a depth of about $55 \mathrm{~cm}$. That is, the upper seedlings of Centaurium vulgare develop in places with the water table at this depth. This conclusion may be drawn from Figs. 6,7 and 8. A difference in water table between two successive years is correlated with the same difference between the two relevant upper limits of the zone of Centaurium vulgare. There is a relation between the phreatic level and the distribution of Centaurium vulgare. In some way or other Centaurium vulgare is dependent on the soil water, which is also suggested by the high level of the soil water below the Centaurio-Saginetum. In view of this relation between Centaurium vulgare and the soil water the Centaurio-Saginetum must be classed in the hygrosere sensu WESTHOFF (1947 b). Hygrosere was defined as sere of plant communities consisting of species depending on the phreatic soil water in their water demands.

Salisbury (1952) and Ranwell (1959) defined the conception "slack". According to the British literature a dune habitat can be regarded as a slack, when the summer water table does not exceed a depth of $1 \mathrm{~m}$. Thus, upper plants of Centaurium vulgare, occurring on levels with a summer water table of $1 \mathrm{~m}$, mark the upper limit of the "slack" or the transition to the dry dune habitat. This picture of Centaurium vulgare as a transition zone plant is in full agreement with the place of the community of Centaurium vulgare as discussed in chapter 2.

\subsection{Centaurium vulgare in transect 1}

More details on the relation between the phreatic soil water and the distribution of Centaurium vulgare were obtained from the study of belt transect 1. This transect was plotted out in the slack near the Biological 
Table 8: properties of the Centaurium-population in transect 1

\begin{tabular}{|l|c|c|c|c|c|c|c|c|}
\hline & \\
10 \\
20
\end{tabular}

Station in 1962. Table 8 shows a longitudinal profile of the transect, which consisted of eight sample plots. The transect was situated at right angles to the zonation and its width was $2 \mathrm{~m}$. (Length and elevation are designated by two different scales in Table 8.) In the profile the relative depths of three soil water tables are shown. They refer to the soil water levels during the germination periods of 1961,1963 and 1964. The last two of these values were measured in pipe 1 near the top of the transect and the first one was obtained from data of two pipes in the immediate neighbourhood of the transect.

The vegetation in transect 1 belonged to the Centaurio-Saginetum. Four vegetation analyses each corresponding to two sample plots were combined in Table 9. (All these analyses can also be found in the vegetation Table 1.) 
Table 9: the vegetation of transect 1

\begin{tabular}{|c|c|c|c|}
\hline Sample plot & $\mathbf{A}$ & B & C \\
\hline Centaurium vulgare & 2 & 2 & 1 \\
\hline Cerastium semidecandrum & + & - & - \\
\hline Phleum arenarium & $\mathbf{r}$ & - & 一 \\
\hline Ammophila arenaria & 1 & $\mathbf{r}$ & - \\
\hline Cerastium atrovirens & 1 & + & - \\
\hline Hieracium umbellatum & $\mathbf{r}$ & + & 一 \\
\hline Anthyllis vulneraria & 1 & + & - \\
\hline Rhinanthus minor minor & + & 1 & $\mathbf{r}$ \\
\hline Festuca rubra arenaria & 2 & 2 & 1 \\
\hline Leontodon nudicaulis & 1 & 1 & 2 \\
\hline Sagina nodosa moniliformis & + & 2 & $\mathbf{1}$ \\
\hline Sonchus arvensis & - & $\mathbf{r}$ & 一 \\
\hline Hippophaë rhamnoïdes & - & $\mathbf{r}$ & $\mathbf{r}$ \\
\hline Carex arenaria & - & + & + \\
\hline Juncus alpinus atricapillus & - & + & 1 \\
\hline Juncus articulatus & - & + & 1 \\
\hline Bryum angustirete & - & 1 & - \\
\hline Lotus corniculatus corniculatus & - & - & $\mathbf{r}$ \\
\hline Carex trinervis & - & - & $\mathbf{r}$ \\
\hline Poa pratensis & - & - & $\mathbf{r}$ \\
\hline Agrostis stolonifera & - & - & 1 \\
\hline Salix repens & - & - & + \\
\hline Carex serotina pulchella & - & - & + \\
\hline Carex flacca & - & 一 & - \\
\hline Euphrasia officinalis & - & - & - \\
\hline
\end{tabular}

Centaurium vulgare - the object of the investigations of transect 1 - was placed at the head of the table and the other species were arranged in order of their occurrence on the gradient from dry to wet. The coverage of the vegetation amounted to $25 \%$ in the whole transect.

Some properties of the population of Centaurium vulgare in the transect were determined: 1. the maximal length of the specimens and the average number of flowers/fruits; for the generation 1964 the diameter of the rosettes, 2. the density of the population i.e. the number of plants on two square metres, 3 . the total numbers of fruits per two square metres. These properties were determined for the adult plants of the generations 1961 and 1963 in the following years. The generation 1964 was investigated in rosettestage in the same year.

From the data given in Table 8 some conclusions on the level of the upper limit of the zone of Centaurium vulgare may be drawn. The upper limit of the generation 1961 was the same as the upper limit of the sample plot A 1. The upper seedlings of the generation 1961 established themselves some $55 \mathrm{~cm}$ above the level of the soil water. In 1964, however, only one 
adult plant of the Centaurium-generation 1963 was found in sample A 1 . In fact the upper limit of the Centaurium-zone was formed by the upper boundary-line of sample plot A 2. Also in 1964, it was observed that rosettes - forming the generation 1964 - only occurred from the upper limit of sample plot B 1 downward. The upper limits of the generations 1963 and 1964 had shifted viz. 2 and 4 metres below the upper limit anno 1962 on the slope of the dune slack. The "vertical" differences between the upper limits of the three generations corresponded to equal differences between the water tables on May 1st in 1961, 1963 and 1964.

Transect 1 showed also the relations between the soil water table and the population pattern of Centaurium vulgare. The figures in the columns of Table 8 should be compared with each other. The plants anno 1961 of the largest size i.e. the specimens with maximal length and the highest number of fruits were found in sample plot A 1. In the other sample plots markedly smaller plants occurred. There was a strong decrease in stem-length and the average number of flowers in the lowest plots decreased to 1 per plant. The plants on the low plots had a reduced vitality in all respects. The density of the Centaurium-plants of the generation 1961 was as follows. In the sample plots A 1 and D 1 the number of plants was about the same. In the area between these plots the density of Centaurium vulgare was about twice as high. The figures referring to the total numbers of fruits can be regarded as the result of density $\mathrm{x}$ vitality. As a consequence of this, high numbers of fruits were found in plots A 1 and B 1 and in the low plots the number of fruits equaled the number of plants.

The generation 1963 showed the same picture. A few dissimilarities were observed: The maximal length of the Centaurium-plants appeared to be smaller. The number of plants and fruits on the whole transect was also lower. So it appears that successive generations of Centaurium vulgare may differ in "biomass". Differences in weather conditions must be the cause.

The diameter of the rosettes of the generation 1964 decreased on the gradient of transect 1 . The density showed the same trend as the generations 1961 and 1963 did. As was the case on the seedling plots on Voorne, many rosettes in the sample plots C 2 - D 2 were yellow and had a reduced vitality. The number of rosettes on the plots B 1 and D 2 was more or less the same as the number of adult plants of the generation 1961 on the higher and the lower sample plot. A greater number of rosettes, however, occurred in the middle of the transect. When this high number is compared with the number of adult plants of the generation 1961 in the same middle zone, it becomes clear that the number of specimens in this zone of highest density is strongly reduced during the life-cycle. The mortality of Centaurium vulgare is highest in the middle zone of the transect. In chapter 3 it was already shown that the mortality of Centaurium vulgare is maximal in dense populations. 
Of ten fruits of distinct plants occurring viz. in the sample plots $A 1$ and B 1 and belonging to the generation 1961 the number of seeds was counted. The average number for the two groups of fruits were viz. 184 and 136. Big specimens of Centaurium vulgare generally have large fruits bearing more seeds. Also in this respect, the higher sample plots of the transect were characterized by "maximal" plants. If 136 is indeed the average number of seeds in sample plot B 1, this means that in $1962800 \times 136$ seeds were produced on sample plot B 1 i.e. on an area of $2 \mathrm{~m}^{2}$. This high number of seeds completely agrees with the nature of Centaurium vulgare as a pioneer plant. According to SAlisbURY (1942) species in open environments, for instance young dunes, are characterized by a high reproductive capacity.

The average size of the plants of the generations 1961 and 1963 on the plots D 1 and C 2 appeared to be somewhat larger than on the higher plot C 1. This deviation of the general trend in the distribution of Centaurium vulgare in the transect can be explained as follows. On the lower part of the transect some plants occurred forming small elevations on the surfage: e.g. Agrostis stolonifera, Salix repens and Carex serotina (see Table 9). The larger average size of Centaurium vulgare on the plots D 1 and C 2 was the result of a larger size of Centaurium-plants occurring on these elevations. Between these more favourable micro-sites the plants of Centaurium vulgare showed a very low vitality and small size. Sometimes these plants only reached adulthood after three years and remained in the rosette-stage for a second year. So it was impossible to decide in a number of cases, whether the plants on plot D 1 in 1964 belonged to the generation 1963 or 1964. This is one of the reasons, why it was very difficult to determine the lower limit of the Centaurium-zone. From the data given in Table 8 it becomes clear that this lower limit did not shift downward as the upper limit did depending on the water table.

Two main facts appeared from the investigation of transect 1.

1. The upper seedlings of Centaurium vulgare emerge $55 \mathrm{~cm}$ above the soil water table. Different levels of the water table cause Centaurium vulgare to grow on different levels.

2. The zone of Centaurium vulgare can be subdivided into three subzones:

a. upper subzone with big plants and low density,

b. middle subzone with plants of medium size and with high density,

c. lower subzone with plants with a reduced vitality and growing wide apart.

It is obvious that the pattern within the Centaurium-zone also depends upon the water factor. Only the water conditions form a gradually changing factor on the dune slope and they are essentially the same on each slope. The relations between the pattern of the Centaurio-Saginetum and the water conditions are discussed below.

The change in density and size of Centaurium vulgare in transect 1 was the cause of a varying abundance according to the scale of Braun-Blanquet 
in Tables 9 and 1 . In chapter 2 attention was paid to this fact. The subdivision of the Centaurium-zone can be distinguished more or less in all stands of the Centaurio-Saginetum. The dry variant of the community on the Boschplaat was characterized by plants of big size. The wet variant - on the contrary - was a biotope of small individuals.

\subsection{Transect 2 and the composition of the Centaurieto-Saginetum}

In 1962 a second transect was plotted out on the steep slope of a small dune slack behind a sea defence-wall near $\mathrm{km}$ coast-mark 16 . The form and size were about the same as those of transect 1 . It was divided in five sample plots each of about $2 \mathrm{~m}^{2}$ size. Table 10 shows the relative heigth of the

Table 10: properties of the Centaurium-population in transect 2

Sample plot

Relative heigth of plots in $\mathrm{cm}$

generation 1961:

length in $\mathrm{cm}$

fruits (av. number)

plants on $2 \mathrm{~m}^{2}$

fruits on $2 \mathrm{~m}^{2}$

generation 1963:

length in $\mathrm{cm}$

fruits (av. number)

plants on $2 \mathrm{~m}^{2}$

fruits on $2 \mathrm{~m}^{2}$

generation 1964:

diameter rosettes $(\mathrm{cm})$

plants on $2 \mathrm{~m}^{2}$

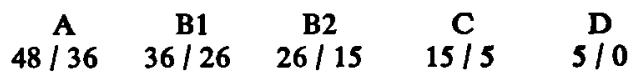

$\begin{array}{ccccc}13 & - & 8 & - & 1 \\ 8,5 & - & 1,2 & - & 1 \\ 30 & - & 330 & - & 35 \\ 265 & - & 410 & - & 35\end{array}$

$\begin{array}{lcccc}0 & 13 & 11 & 7 & - \\ 0 & 2,1 & 1,6 & 1,5 & - \\ 0 & 27 & 43 & 27 & - \\ 0 & 57 & 70 & 40 & - \\ & & & & \\ 0 & 1 & 3 & <1 & - \\ 0 & 1 & 27 & >100 & -\end{array}$

sample plots and the results of the counts which were carried out in this transect. With regard to the Centaurium-generations of the years 1961, 1963 and 1964 the same features were determined as in transect 1.

The upper limits of the generations 1961, 1963 and 1964 lay below each other. The differences in elevation of the upper limits 1963 and 1964 from the limit 1961 amounted to 12 and $22 \mathrm{~cm}$ respectively. These differences were slightly greater than in the case of transect 1 . It was not possible to compare these levels of the upper limit of the Centaurium-zone with the water table of this site, because no measurements of the soil water levels were made here. From the figures of Table 10 it appears that the plants of Centaurium vulgare showed the same pattern as in transect 1 . The numbers of specimens were well comparable with those of transect 1 . Also the values of other features corresponded very well. So it may be concluded that the results of transect 1 were confirmed by the data obtained in transect 2 . 
Table 11: the vegetation of transect 2

Sample plot

Area in $\mathrm{m}^{2}$

Cover in \%

Centaurium vulgare

Rhinanthus minor minor

Cerastium atrovirens

Jasione montana

Brachythecium albicans

Corynephorus canescens

Elytrigia juncea

Tortula ruralis ruraliformis

Anthyllis vulneraria

Hieracium umbellatum

Ammophila arenaria

Festuca rubra arenaria

Leontodon nudicaulis

Carex arenaria

Hippophaë rhamnoides

Sagina nodosa monilif.

Viola canina

Linum catharticum

Juncus bufonius

Lotus corniculatus corn.

Agrostis stolonifera

Juncus alpinus + articul.

Salix repens

Bryum angustirete

Calamagrostis epigejos

Carex serotina pulchella

Nostoc sp.

Parnassia palustris

Radiola linoides

Carex flacca

Hydrocotyle vulgaris

Mentha aquatica

\begin{tabular}{|c|c|c|c|}
\hline$\underset{2 \times 1}{A}$ & $\begin{array}{c}\text { B } \\
2 \times 1,5 \\
30\end{array}$ & $\begin{array}{c}C \\
2 \times 1 \\
50\end{array}$ & $\begin{array}{c}\mathrm{D} \\
2 \times 0,85 \\
40\end{array}$ \\
\hline $\begin{array}{l}\text { (1) } \\
\text { (1) }\end{array}$ & $\begin{array}{c}2 \\
(2)\end{array}$ & $\begin{array}{l}2 \\
r\end{array}$ & 1 \\
\hline 1 & - & - & - \\
\hline+ & - & - & - \\
\hline r & $\overline{ }$ & - & - \\
\hline 1 & (r) & - & - \\
\hline $\mathbf{r}$ & $\mathbf{r}$ & 一 & 一 \\
\hline+ & + & - & - \\
\hline 2 & 1 & (r) & - \\
\hline+ & + & $\mathbf{r}$ & - \\
\hline+ & 1 & $(+)$ & $\mathbf{r}$ \\
\hline 1 & 2 & 2 & 1 \\
\hline $\begin{array}{l}+ \\
+\end{array}$ & $\begin{array}{l}+ \\
+\end{array}$ & 2 & 1 \\
\hline$\underset{\text { (r) }}{+}$ & $\stackrel{+}{+}$ & + & 1 \\
\hline (r) & (2) & (1) & (r) \\
\hline - & $\mathbf{r}$ & - & - \\
\hline - & 1 & - & - \\
\hline - & + & - & - \\
\hline-+ & $\mathbf{r}$ & (I) & 一 \\
\hline - & 1 & 1 & 1 \\
\hline- & 1 & 1 & 1 \\
\hline- & $\mathbf{r}$ & 1 & 3 \\
\hline- & 1 & 2 & + \\
\hline $\bar{Z}$ & ${ }_{-r}^{+}$ & $\stackrel{r}{r}$ & $\overline{1}$ \\
\hline- & 1 & 3 & + \\
\hline- & - & $\mathbf{r}$ & - \\
\hline- & 一 & + & $\mathbf{r}$ \\
\hline - & - & + & 1 \\
\hline- & - & (r) & $\mathbf{r}$ \\
\hline- & & - & $\mathbf{r}$ \\
\hline
\end{tabular}

Table 11 is a survey of the vegetation of transect 2 . The vegetation of the two sample plots B 1 and B 2 is rendered by one analysis. The other analyses represent one sample plot each. The vegetation was composed of more species than that in transect 1 . Among them the dry species Jasione montana and Corynephorus canescens occurred. This means that vegetation and environment of transect 2 were older than those of transect 1 . The figures in the columns form an expression for abundance and dominance of 
the species in the vegetation period of 1962 . The vegetation was studied in 1964 again. The abundance/dominance values of species lacking in 1964 are placed between brackets. The new establishment of species in 1964 is designated by abundance figures placed beside the columns. By this the change of the vegetation is shown and a comparison between the vegetations anno 1962 and 1964 is made possible.

The comparison of the data in Tables 10 and 11 is interesting in view of the composition of the Centaurio-Saginetum. In 1962 the upper zone of the Centaurium-belt was the same as sample plot A. That is, the well-developed specimens of Centaurium vulgare occurred in a vegetation represented by analysis A. In this vegetation only xerosere plants occured. The biggest adult plants of the generation 1963 and the big rosettes anno 1964 were found in a vegetation the composition of which is represented by analysis B. In this vegetation less xerophytes and more mesophytes and hygrophytes occurred. A comparison of columns 1 and 2 in Table 11 shows that the vegetations just-mentioned had only nine species in common. The number of differential species amounted to fourteen. So there was a great difference in floristic composition between the upper Centaurium-zone of 1962 and the one of 1964. In 1962 the plants of Centaurium vulgare, germinated in the preceding wet year, grew in a dry xerosere-vegetation. Plants, germinated in the dry spring of 1963 , occurred on a lower level in 1964, namely in a rather wet hygrosere-community. In other words, after a preceding wet season the Centaurio-Saginetum is composed of xerophytes and after a dry spring a Centaurium-community in the next year consists mainly of hygrophytes. In the discussion on the plant community of Centaurium vulgare the dry and wet forms of the community were regarded only as variants. A division of the association in a dry and a wet subassociation was not justified, because there are no substantial differences between these forms. From Table 11 appears that the classification of a concrete vegetation of Centaurium vulgare not only depends on its elevation but also on the time of investigation.

Table 11 shows that Rhinanthus minor ssp. minor and Sagina nodosa showed a strongly fluctuating abundance in transect 2 . The former plant is a remarkable belt plant on the slopes of the slacks on Terschelling. Probably this annual plant shows a similar behaviour as Centaurium vulgare does.

\subsection{The capillary water in dune soils}

In the previous sections it was discussed that the level of the soil water table influences the level of the upper limit of the Centaurium-zone. The maximal distance between soil water table and seedlings of Centaurium vulgare appeared to be $55 \mathrm{~cm}$. Fluctuations in the phreatic level are related to changes in the distribution of Centaurium vulgare. 


\subsubsection{Some definitions}

The forms of the soil water and their distribution in the dune soil can be placed in the following scheme, which is mainly based on data from the handbook by RoDE (1959). A definition of the distinct types of soil water is necessary for the discussion of the phenomenon of capillary activity and it is useful in view of the occurrence of some of the defined terms in other parts of the present publication.

a. As was mentioned before the soil water table or phreatic level occurs at a certain depth in the dune soil. All water below this level is called phreatic soil water or ground water.

b. By the influence of capillary forces part of this ground water rises in the narrow capillaries of the soil. The heigth of this capillary rise is determined by the diameter of the soil capillaries, in its turn the average diameter depends upon the size of the soil particles. This is the reason why in general the capillary rise in sandy soils is much lower than in fine-grained soils like loam and clay. The rising capillary water is in open contact with the ground water; there is a hydrostatic equilibrium between these two types of soil water. By Rode the rising capillary water is called "borne-capillary" water (German: getragenes kapillares Wasser). The soil layer just above ground water is more or less moistened by the rising capillary water. This soil layer is called the capillary fringe, the capillary surface forming its upper limit. As a consequence of the interdependence of the rising capillary water and the ground water, fluctuations of the phreatic level influence the depth of the capillary fringe and the level of the capillary surface. This is an important feature for the explanation of the relation between Centaurium vulgare and the soil water table.

c. Soil moisture is soil water without further specification. It is the solvent for $\mathrm{C} 1$-ions and plant nutrients. In this study the content of soil moisture was determined by drying $\left(105^{\circ} \mathrm{C}\right)$. The soil moisture can be composed of three categories of soil water: rising capillary water, "hanging"capillary water (Dutch: hangwater; German: hängendes Wasser) and gravitational water. The gravitational water occurring in the wider pores of the soil after rainfall moves downward and is not important for the water consumption of plants during longer periods. Also above the capillary fringe water bound by capillary forces may occur. This category of water "hanging" in the soil profile is not dependent on the ground water. In hydrology much attention is paid to this form of soil water. This "hanging" capillary water is the important water source for plants on arable land (see for instance VeIHMEYER 1956). In dune soils especially in the soil of the Centaurio-Saginetum the other forms of water 
play a much more important part in the ecology of plants. In the following section attention will be paid to some properties of the rising capillary water, briefly called "capillary water" hereafter.

\subsubsection{The heigth of the capillary rise}

There is a difference in capillary rise in dry and wet material. This phenomenon is called "capillary hysteresis" (RoDe 1959). It may be briefly described as follows. The capillary rise or the length of a column of water held by capillary forces depends upon the diameter of the meniscus: the smaller the meniscus, the longer the column of water. When a column of sand in a glass cylinder or a sandy soil is moistened from above and the water goes downward, meniscuses are formed in narrow places of the capillaries in the sand. Thus long "threads" of water are formed from the meniscuses to the base of the column, which is placed in a container with water, or to the water table in the soil. However, when the water must move in the opposite direction it cannot reach the same height in the column of sand or in the soil profile. Before the rising capillary water can form meniscuses in narrow places on a high level in the sand column or the soil, it has always to pass wider interstices, which only can hold a shorter capillary thread. This is the consequence of the irregular diameter of the soil interstices and capillaries.

This picture of capillarity is also true with regard to dune soils. Theoretically there are two possible capillary surfaces and two capillary fringes in dune soils. In the dry dune soil in summer the capillary water has to rise actively in the soil profile. This capillary rise can only reach low values. The records of the following authors refer probably to this kind of capillarity: VersLuYs (1916) - $30 \mathrm{~cm}$, Westhoff (1947 b) and Groenewoud (1962) $-40 \mathrm{~cm}$ for dune sand; WALTER $(1960)-30 \mathrm{~cm}$, Lyon et al. (1956) $-40 \mathrm{~cm}$ for sandy soils without any further specification. In spring different circumstances prevail in the dune soil. During the winter the level of the water table is high and the whole soil profile is water-logged. The loss of water through evaporation and transpiration is low. Under such circumstances the dune soil may be compared with a column of sand moistened from above and a capillary fringe with a size of $50-60 \mathrm{~cm}$ can be built up. ENGELHARDT (1928) investigated capillarity under dry and wet circumstances. Apart from his investigations with columns of sand he experimented with the so-called capillarity-meter. He measured a maximal capillary rise of $63 \mathrm{~cm}$ in sea sand of almost the same composition as that of the sand on Terschelling. WILLIS et al. (1959) investigated the moisture content in dune soil profiles. Some $50 \mathrm{~cm}$ above the water table the soil moisture content appeared to be influenced by the ground water. The capillary rise in dry sand of the same composition and origin was only $30 \mathrm{~cm}$. Also RaNwell (1959) compared 
the moisture in the dune soil profile with the capillarity and he drew the conclusion that the capillary rise could amount to $45 \mathrm{~cm}$. According to GoETHART et al. (1924) the capillary activity in dune soils has a maximal value of $50 \mathrm{~cm}$. This conclusion was based on their investigations on the distribution of 91 dune plants, 65 of which appeared to occur $0-60 \mathrm{~cm}$ above the phreatic level during summer. These "ground water-species" were regarded to be dependent on the ground water.

\subsubsection{The importance of the capillary water for Centaurium vulgare}

The relation between the distribution of Centaurium vulgare and the soil water table may be explained as follows. Under favourable conditions prevailing in spring the capillary rise in dune soils amounts to $55 \mathrm{~cm}$. To a heigth of $55 \mathrm{~cm}$ above the soil water table the moisture content in the profile or at the surface of the dune soil is increased by capillary water. This increase of the moisture content at the soil surface is apparently necessary for the germination of Centaurium vulgare in its normal habitat. Centaurium vulgare does not occur beyond the influence of the capillary water. Differences in ground water level between successive springs are the reason why the level on the dune slope moistened by capillary water varies and the upper limit of the Centaurium-zone fluctuates.

From observations of the present author and from the investigations of WiLlis et al. (1959) and RANwell (1959) it appeared that there is a gradient in the water content of the capillary fringe. The water content in the soil layer reached by the capillary water decreases in the upward direction. The situation on the dune slope surface, as far as it is moistened by the capillary water, is analogous. The lower the level on the slope the more it is moistened by capillary water. The soil surfaces of the two lower subzones of the Centaurio-Saginetum receive more water from below than the upper zone. If the soil moisture content influenced by the capillary water determines the upper limit of the zone in which seedlings of Centaurium vulgare are found, it is probable that the whole distribution pattern of seedlings is related to soil moisture and again the amount of capillary water. In chapter 5 the actual values of the soil moisture in the different forms of the Centaurio-Saginetum will be treated and after this the population structure of Centaurium vulgare will be discussed once more.

\subsection{Remarks on the fluctuating upper limit of the Centaurium-zone}

As a consequence of fluctuations of the water table and the capillary surface the upper limit of the Centaurium-zone in successive years moves upwards and downwards along the dune slopes. The plants of Centaurium vulgare forming the so-called upper subzone occur on alternate levels of the 
slope and the Centaurio-Saginetum - at least where it is most typically developed - varies in composition. It may be said that Centaurium vulgare fluctuates in the transition zone between hygrosere and xerosere.

Besides the transects 1 and 2 a fluctuating upper limit of Centaurium vulgare was observed in many other sites. In 1962 Centaurium vulgare occurred in many places of the eastern point of Terschelling on a higher level than in 1963 and 1964. Moreover, Centaurium was much more abundant in 1962. Probably there is a relation between the shifting upper limit and the abundance of Centaurium vulgare. It is possible that on a higher level in the duneland more open vegetations and thus more favourable environments for Centaurium vulgare are to be found. The occurrence on higher parts of the dune slopes may coincide with a higher abundance of the species. In the discussion on the density of Centaurium vulgare in the transects it was made clear that the numbers of specimens also vary on lower levels. Also other factors affect the abundance of the species. The varying numbers of Centaurium-plants were well known by the old people of Terschelling, who collected the plants in earlier times, because Centaurium vulgare was regarded as a febrifuge. (Fournier (1947) and Zwaving (1966) gave data on the medicinal importance of Centaurium-species.)

The fluctuations of Centaurium vulgare were observed by some other Dutch botanists. LoNDo (1963, pers. comm.) observed that Centaurium vulgare germinated on different levels on the slope of a newly dug dune lake near Haarlem during successive years. WESTHOFF (1963) reported a difference in abundance of Centaurium vulgare in 1963, compared with 1961 and 1962, on the island of Goeree. In the dunes of Voorne VAN DER MaArel and Van Der MaArel-VersluYs (1963) observed fluctuations of the species Centaurium vulgare and minus and Blackstonia perfoliata. The occurrence of these species on higher levels in the dune area during 1962 is regarded by these authors as a consequence of a higher humidity in that season. This may be true for the annual plant Blackstonia, but in the case of the biennial Centaurium-species the weather conditions of the preceding season must be the reason.

Without doubt several species, especially those with a short life-cycle, occur on alternate levels in the dune area. SchotSMAN (1956) described the relation between Parnassia palustris and the soil water table. The distribution of this species on the Boschplaat appeared to have two features in common with Centaurium vulgare. The seedlings of this plant established themselves on different levels during the observation period. This ecological behaviour was determined by the soil moisture. Also, the zone of Parnassia consisted of subzones with plants of different size. However, the biggest plants of Parnassia occurred in the middle subzone.

The part of dune slopes on which Centaurium vulgare occurs, is situated between the always wet slack bottom and the generally dry dune top. The 
belt of the dune slope, where the upper limit and upper subzone of the Centaurio-Saginetum fluctuate, is periodically influenced by the ground water and its capillary water in the course of the vegetation period and in successive years as well. In contrast with the more stable conditions of slack and top viz. always wet and often dry, the intermediate environment on the slope is characterized by water conditions of high instability. It is not correct to regard the dune slope only as a gradual transition between the dry and the wet dune environment, because it is also a contact zone, a separate environment typified by the instability in time with regard to the water factor. Recently such border situations were studied by VAN LEEUWEN (1965 and 1966; see also Van Der MaArel et al. 1964). The young dune slope can be classed as a "limes convergens" situation in the system of Van Leeuwen. Apart from the fluctuating upper limit, some properties of Centaurium vulgare and its community confirm its affinity to the convergent borderline communities sensu Van Leeuwen. The transition from dune top environment to dune slack habitat is abrupt. Vegetations of the CentaurioSaginetum are open and consist of many individuals of few species. Centaurium vulgare is the most typical species of this convergent dune slope environment. This indicator species is best developed on that part of the dune slope, where the convergent character is most strongly developed i.e. the upper zone of the Centaurio-Saginetum. On the edge of the area influenced by the capillary water - where the fluctuations of the water conditions are strongest - the best developed specimens of Centaurium vulgare occur. The size and vitality of this species with a preference for unstable conditions diminish under more stable conditions e.g. on low levels of the dune slope. Besides, Centaurium vulgare disappears on dune slopes where the discrepancy between the two contrasting environments decreases. This is the case on older dune slopes, where a dense vegetation or litter on the soil surface create moderate moisture conditions. The terminal stage of the CentaurioSaginetum discussed elsewhere in this publication, is found here. 


\section{Chapter 5:}

\section{CENTAURIUM VULGARE AND THE SOIL MOISTURE}

\subsection{Introduction and method}

After a discussion of the relations between the phreatic level and the distribution of Centaurium vulgare in the preceding chapter a survey of the soil moisture conditions for Centaurium vulgare will be given below. Two series of Centaurium-sites were investigated. The results of three Centauriumhabitats in dune slacks and a series of sites situated in a transect on the salt marsh Boschplaat are discussed. Like the phreatic level the soil moisture on the salt marsh depends upon the movements of the sea water.

Two soil layers were sampled separately, namely a superficial layer from 0 to $1 \mathrm{~cm}$ and a subsurface layer from 1 to $20 \mathrm{~cm}$. The upper layer forms the substratum for the germinating seeds and as such it deserves special attention. Besides, interesting fluctuations in the water content of this layer were expected as in the case of the related plant community Sagino-Cochlearietum. The subsurface layer forms the environment for roots of normal Centaurium-plants. These layers in the "profile" were sampled, respectively, by means of a stopping-knife (Dutch: plamuurmes) and a fine soil borer commonly used in the agriculture (Dutch: landbouwboor, DE VRIEs and Dechering 1960) Each soil sample was composed by taking at least five "sub"-samples.

The water retention of dune soils is very low, fluctuations in water percentage occur frequently (SALisbury 1952). Incidental determinations of soil moisture have little value. All sites investigated were sampled twelve times during the vegetation period 1964. It appeared that such fortnightly samplings are frequent enough to assess the seasonal fluctuation and occasional influences of showers and high tides. The soil moisture was expressed as percents, by weight, of stove dried soil $\left(105^{\circ} \mathrm{C}\right)$. According to SALISBURY (1952) the soil moisture in dune soils is strongly influenced by the amount of organic matter. When comparing soils of different humus content preference should be given to express the moisture content as percents by volume. In our case, however, all soils investigated, except the one of site 4, were very poor in organic material.

\subsection{The soil moisture in the Centaurieto-Saginetum}

\subsubsection{Brief description of the slack sites}

A series of three Centaurium-sites situated in young dune slacks was investigated: 
site 1:

a slope of a small secondary dune slack, dug in 1956-1957, 150 m west of the Biological Station and just behind a second sea defence-wall; upper subzone of the Centaurio-Saginetum, analysis M1 in Table 1.

site 2:

idem, $150 \mathrm{~m}$ east of the Biological Station; lower subzone of the CentaurioSaginetum, analysis M2 in Table 1; markable cover of algae.

site 3:

the bottom of a small primary dune slack between the yellow dunes near $\mathrm{km}$ mark 20; Centaurio-Saginetum, analysis M3 in Table 1.

\subsubsection{Discussion of Table 12 and Fig. 9}

In the soil of site 1 a high water content was measured in the spring. A sharp decrease in soil moisture occurred in May, the minimal value of soil moisture was found in June. Later in the year the soil moisture content increased again. The curve in Fig. 9 representing the moisture content in the subsurface layer parallels the curve representing the soil water table in the near-by ground water pipe (Fig. 6). This proves that there is a strong

Fig. 9: percentage of soil moisture, by weight, of Centaurium-sites in slacks

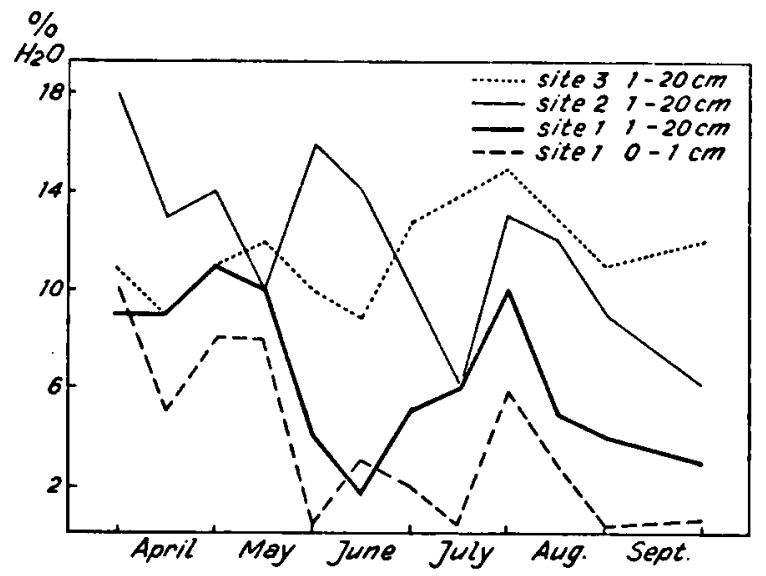

relation between the soil water table and the soil moisture in the CentaurioSaginetum as discussed in the previous chapter. In periods with a high water table the water content of the habitat of Centaurium vulgare is directly determined by the ground water. During spells of dry weather the phreatic level falls and the topsoil becomes desiccated, because it is no longer 
moistened by capillary water. The curve for the topmost layer of $1 \mathrm{~cm}$ on site 1 parallels that of the $1-20 \mathrm{~cm}$ layer. In the open vegetations of the typical Centaurio-Saginetum the surface layer is continuously drier as a result of a smaller influence of the capillary water and the high evaporation. This regularity may be interrupted by rainfall. On June 16th sampling was carried out during rainfall and the moisture content at the surface was higher because of this. From the moisture conditions on site 1 is clear again, why germination in spring is of adaptational value for Centaurium vulgare. In the upper subzone of the Centaurio-Saginetum the substrate of the seeds may become almost completely desiccated from May till October.

In spite of the fact that the upper part of the Centaurium-zone must be regarded as a rather dry habitat, its soil moisture content is sufficient for the water consumption of Centaurium vulgare and other species of its community. Even the driest samples taken on site 1 contained more water than the amount corresponding to the wilting point in dune sand. This amount is

Table 12: percentage of soil moisture, by weight, of slack sites

\begin{tabular}{ccccr} 
site & layer in cm & \multicolumn{2}{c}{ range } & mean \\
1 & $0-1$ & 0,2 & $-10,4$ & 4,0 \\
& $1-20$ & 1,7 & $-10,6$ & 6,5 \\
2 & $0-1$ & $1,5-15,2$ & 8,6 \\
& $1-20$ & $6,3-17,5$ & 11,8 \\
3 & $0-1$ & $7,6-15,7$ & 12,2 \\
& $1-20$ & $9,1-15,0$ & 11,6
\end{tabular}

$1 \%$ according to De Vries and Dechering (1960), and Salisbury (1952) mentioned the still lower percentage of 0,5\%. Although our fortnightly samplings were rather frequent, it is possible that more unfavourable water conditions occurred between the sampling dates. In general the soil of the Centaurio-Saginetum seems never, or only exceptionally, to fail in the water supply. This agrees with the relation of the community to the hygrosere. Dead plants of Centaurium vulgare were only occasionally found in the field. These plants died possibly as a result of the combined negative influence of water shortage and high salinity.

The soil moisture in the lower subzone of the Centaurio-Saginetum is much higher during the vegetation period. In the soil of site 2 the water contents found amounted to $50 \%$ of the water capacity of dune soils. Such water conditions are unfavourable for the growth and development of plants of Centaurium vulgare. Several times already attention has been drawn in this publication to the unfavourable influence of too much water in the soil. The lower limit of the distribution area of Centaurium vulgare in dunes is determined by the water factor. The same is true for many other dune plants 
(RANWELL 1959). The water content of a soil is complementary to the quantity of oxygen. Possibly Centaurium vulgare needs a well aerated soil for the roots to function well. The curve representing the soil moisture content of site 2 is not quite parallel to the similar curve for site 1 . In the first half of June extraordinary high water contents were measured, the cause of which could not be found.

Whereas the other moisture curves showed a gradual fall from a high spring level to the low autumn values - with fluctuations - in the dune slack of site 3 rather stable moisture conditions prevailed. The amplitude of the variations was small and the average level was high. There are two explanations for the stability of the water economy here. First this slack was situated between high dune tops, from which water seeped away. In the second place, the position of the slack on the edge of the dune area may be the cause. On the borders of a dune area there is a permanent supply of ground water from the higher middle parts of the dune complex. However, an extreme high ground water table and a high soil moisture level do not occur, because the discharge of water is much easier in the outer dunes (Ter Hoeve 1951; Willis et al. 1959).

DE BRUYN and Borrias (1964) investigated the soil moisture of some biotopes of Centaurium vulgare in the Noordvaarder-dunes and in the area "km marks 6-8". They generally found the same extreme values, but in some cases the range of the soil moisture fluctuations was different. The data of Table 12 and Fig. 9 certainly do not give a complete survey of all possible moisture conditions in the Centaurio-Saginetum of dune slacks.

\subsection{The soil moisture of the Boschplaat-sites}

\subsubsection{Brief description of the sites}

site 1:

top of a horseshoe dune with an elevation of $250-225 \mathrm{~cm}+$ N.A.P. (= New Amsterdam Level), the vegetation belonged to the Koelerion albescentis (Table 2a). Centaurium vulgare occurred very rarely in this environment.

site 2:

bare zone of a horseshoe dune with an elevation of $155 \mathrm{~cm}+$ N.A.P. The vegetation belonged to the Centaurio-Saginetum subass. saginetosum, dry variant (vegetation analysis $\mathrm{M7}$ in Table 2).

site 3:

foot of the sanddike on the Boschplaat with more or less the same elevation and vegetation (analysis M1). 
site 4 :

small ridge in Tweede Duintjes; terminal stage of the Centaurio-Saginetum saginetosum with a high coverage. The toplayer of the soil was darkened by organic matter. The cover of mosses, lichens and algae was notable.

site 5:

open patch in a Juncetum gerardii-vegetation around the foot of a horseshoe dune. The elevation was $145-135 \mathrm{~cm}+$ N.A.P. The vegetation belonged to the saline variant of the Centairio-Saginetum subass. of Sagina maritima (analysis M5). On this site there were still more mosses (35\%) and algae $(25 \%)$. The $0-1 \mathrm{~cm}$ layer contained $3,4 \%$ organic matter and $6 \%$ silt and clay together.

site 6:

transition vegetation along the sanddike (Table 2b). The elevation was $127 \mathrm{~cm}+$ N.A.P.

\subsubsection{Discussion of Table 13 and Fig. 10}

The variations in soil moisture content of the Centaurio-Saginetum saginetosum on the Boschplaat were related to the fluctuations of the water table in 1964, as shown in Fig. 8. Soil samples taken on April 1st and 29th contained much water. The lower values found on the intermediate date were related to a low point of the ground water curve. With the fall of the soil water table during May, the moisture content of all sample sites strongly decreased and on June 15 th minimal values were found in the subsurface layer, the upper soil layer being again wetter. During the summer medium values were measured and, in contrast with the slack sites, the moisture values increased already in the second half of the summer. The influence of the tides of the Wadden Sea on the soil water table and the whole water economy of the Boschplaat varies locally. Some places are more exposed to the sea. The horseshoe dunes on which the sites 2 and 5 were situated, happened to be in an area easily reached by the flood-water. The high soil moisture content of these sites on July 14th may be the result of two spring tides in the preceding fortnight.

The soil of the tops of the horseshoe dunes is not reached by the capillary water. Environment and vegetation belong to the xerosere. For their water consumption plants depend on the "hanging" capillary water. It is clear that in consequence of evaporation and transpiration and without any supply from below the water amount is often very small during the warm and dry season. Many plants are adapted to this situation by a dormancy period or a long root system. Centaurium vulgare is out of place here. Occasionally some specimens of Centaurium vulgare were found in this environment, due 
$\pm \quad$ 音

$=$ ब.

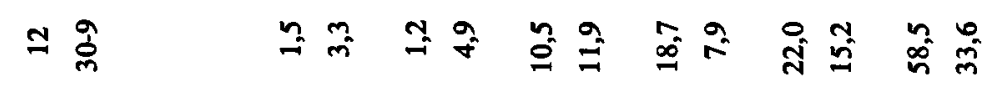

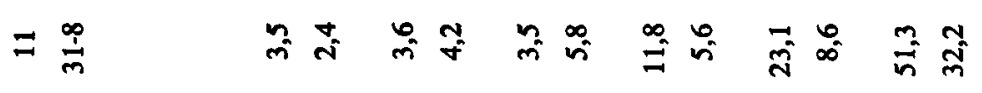

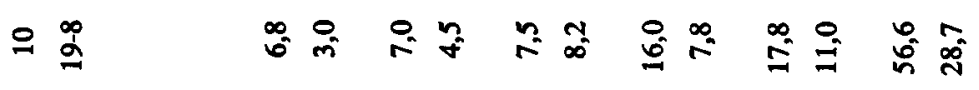

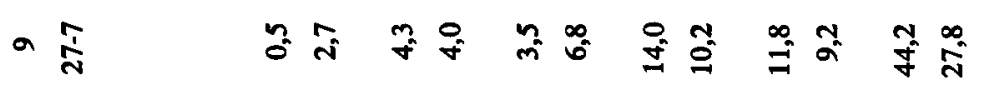

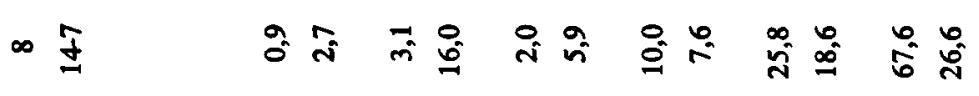

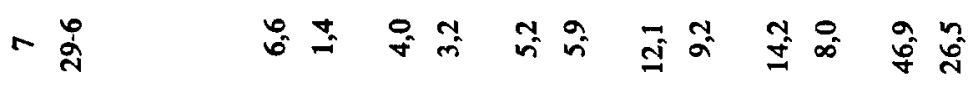

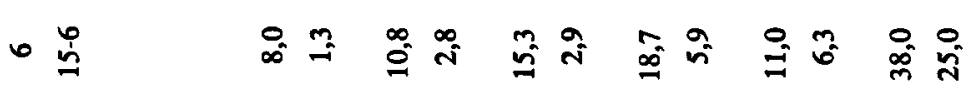

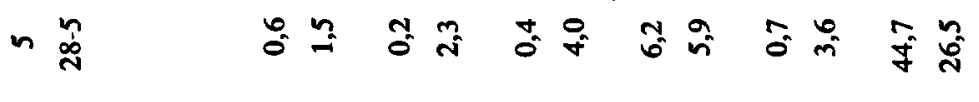

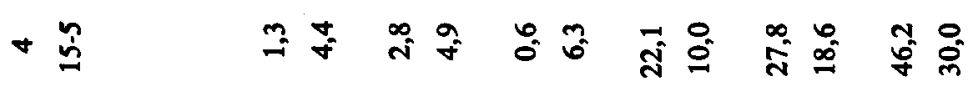

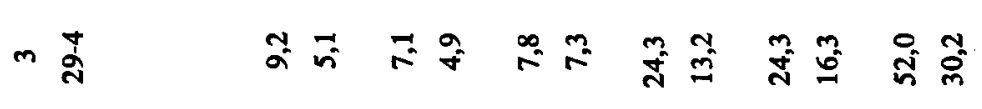

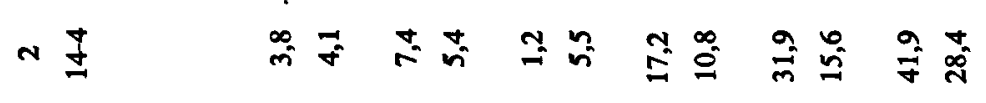

- I किष

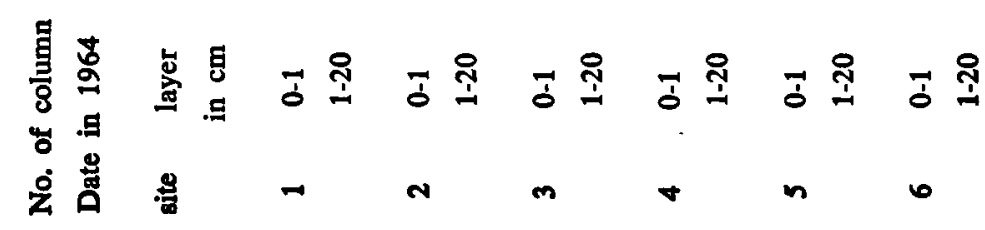


to particular conditions in micro-habitats e.g. in the shadow of tussocks. The dry variant of the Centaurium-community, occurring on the bare zones of horseshoe dunes and in similar places is characterized by a fluctuating low moisture level. Site 2 and 3 showed that the $0-1 \mathrm{~cm}$ layer may become strongly desiccated. Rainfall caused the extreme wetness of the samples taken on June 15th. This environment, where often the biggest specimens of Centaurium vulgare were found, corresponds to the upper subzone of the Centaurio-Saginetum in slacks. As was mentioned above dune groups with a

Fig. 10: percentage of soil moisture, by weight, in $0-1 \mathrm{~cm}$ layer of different Centaurium-sites on the Boschplaat

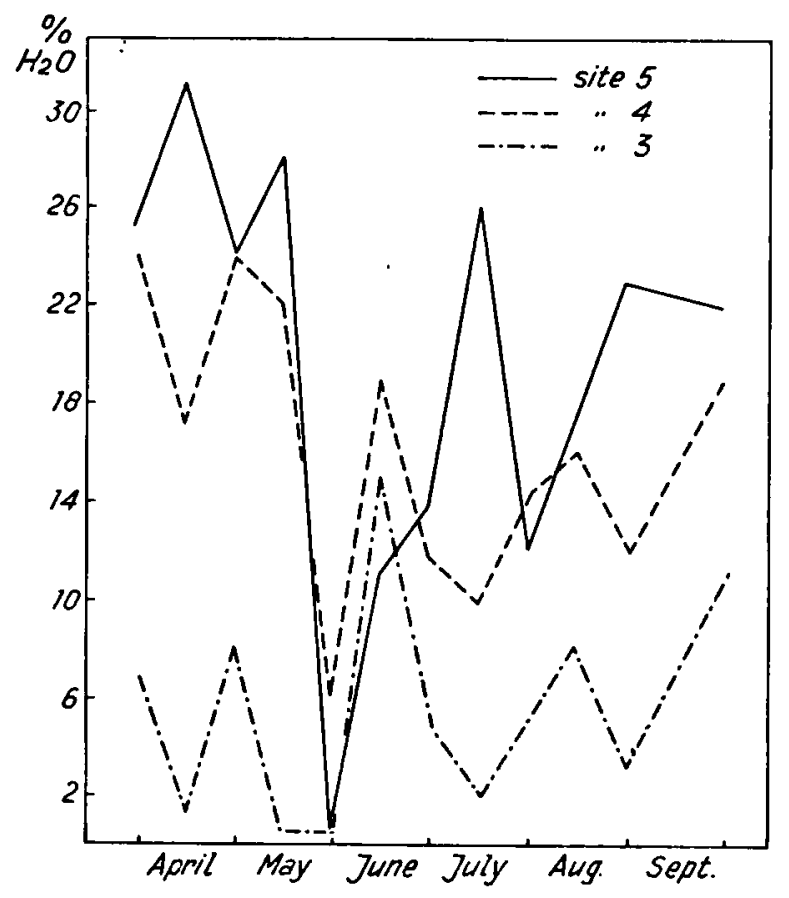

long history and an advanced development occur on the Boschplaat. In one of these dune groups a Centaurio-Saginetum stand (site 4), older than any other Centaurium-site treated in this chapter, was studied. In this terminal stage of the Centaurium-community more stable moisture conditions prevailed. The organic material of the superficial soil layer could retain more water. Together with a lower elevation the wet variant of the Centaurium-community has a wetter soil. The most conspicuous feature of this environment was the silty layer on the surface. The water capacity of this layer was rather high. It could hold far more water, but on the other hand it became completely 
desiccated sometimes. Thus the wet variant is typified by a wide amplitude of the moisture fluctuation. In this respect it resembles the soil on which the association Sagino-Cochlearietum occurs (BEEFTINK 1965 and WeSTHOFF et al. 1961). Desiccation of the topsoil causes a high salt concentration and even crystallization of salts. The crystallized salts and the dried algae, which grow abundantly in this habitat, cause the formation of a thin crust. The communities occurring on lower levels on the Boschplaat e.g. the vegetation of sample site 6 , had a continuously water-logged soil. The superficial soil often had the highest water content owing to the presence of silt and microorganisms. For Centaurium vulgare these water conditions become maximal and it disappears from the vegetation.

\subsection{The relations between the soil moisture and the population pattern of Centaurium vulgare}

During the investigations on the ecology of Centaurium vulgare the water economy of the environment was elaborately studied. Relations between the water factor and the distribution pattern of Centaurium vulgare were found. In this section these relations are briefly reviewed and connected with the influence of Centaurium-plants on each other.

In the xerosere the low soil moisture content prevents the germination and establishment of Centaurium vulgare. In the so-called upper subzone of the Centaurium-community the influence of the capillary water is perceptible and it allows the germination of Centaurium vulgare. However, the water content is still minimal. The seedlings have a scattered distribution. This pattern shows that germination is only possible in a number of microhabitats, where the water conditions are apparently favourable. It may be supposed that only those seeds germinate, which lie in the pores of the soil surface, where a higher humidity occurs. Small differences in the relief of a substratum and the difference in humidity as a result of this, may be determining for germination as was shown by HARPER et al. (1965). Other factors, too, play a part in the germination and the distribution of the seed, but the pattern of moisture conditions in the habitat seems to be of crucial importance. Because the juvenile plants of Centaurium vulgare in this environment are widely interspaced, they exert no influence on each other. There is no competition and each specimen can fully develop. In the upper subzone the biggest plants are found. Also solitary plants on lower levels have a bigger size than specimens in dense populations. Apart from the absence of interference the development of Centaurium vulgare is favoured by the properties of the abiotic environment. In section 4.7 it was discussed that the instability of the water conditions in the upper subzone may be regarded as favourable for Centaurium vulgare.

In the middle subzone of the Centaurio-Saginetum the whole soil surface 
can be regarded as a sufficiently wet substrate for germinating seeds. The density of the seedlings is very high, indeed. Apparently the negative influence of the specimens on each other is an important process in such dense populations of juvenile plants. Immediately after germination many juvenile rosettes turn yellow and die. Also in dense vegetations of older rosettes or adult plants mortality is clearly a result of interference within the species. Another consequence of the competition is a smaller size of the individuals. The plasticity of the plant size as a possible result of interference was reported for a number of weeds by BLEASDALE (1960) and HARPER (1960). Shortage of water or light cannot be the reason of interference between the specimens of Centaurium vulgare, because the water content is high and the vegetations are rather low and very open. It is obvious that the amount of available nutrients is the restrictive factor, the more so because young dune soils are poor in nutrients. This was more or less proved in experiments in which fertilizers were added to the soil. Under these circumstances, Centaurium vulgare can form very dense populations of big plants.

In the lower subzone the number of seedlings is, again, low. It is not known, whether the maximal soil moisture content directly effects this low density. Anyhow, the presence of some phanerogams and the cover of algae or mosses caused by an increase of moisture level is certainly unfavourable. In spite of the wide interspaces between the juvenile plants and therefore the absence of interference, Centaurium vulgare can hardly grow in this habitat. Oxygen deficiency may be the cause.

Zonal populations - complete or incomplete - of Centaurium vulgare may be found in natural vegetations of the Centaurio-Saginetum. These patterns can be studied even more easily on field plots without any other plants, as was done on the Boschplaat (FREIJSEN 1967). 


\section{Chapter 6:}

\section{CENTAURIUM VULGARE AND THE SALINITY OF THE SOIL}

\subsection{Introduction}

Centaurium vulgare - except the ssp. uliginosum - is a true littoral species in NW. Europe. This fact points to the relation between the distribution of the species and the salt factor. Many floras covering the NW. European part of the distribution area of Centaurium vulgare report this plant for places with a sandy, somewhat saline soil. (See the literature referred to in section 1.9.) In general, two habitats are distinguished: on the one hand young, almost desalinated dune slacks and beach plains and on the other hand higher zones of salt marshes. These data from the literature were confirmed by the description of the plant communities of Centaurium vulgare given in chapter 2.

IVERSEN (1936) regarded Centaurium vulgare as a halophyte and classed it in the group of oligomesohalobious species. According to Iversen an "Oligohalobientyp" is a species occurring in places with a slightly saline soil. Iversen tried to introduce a new terminology for salt plants, as the term "halophyte" might suggest morphological adaptations. Orginally the term "halophyte" was a purely ecological designation. The definition of a halophyte can be formulated as follows: a species or plant occurring in an environment characterized by a salt level which is abnormally high during some period in the life-cycle of the plant, so that most species, namely the glycophytes, cannot grow in this environment. This salt level may be formed by $\mathrm{NaCl}$ in the case of marine and littoral halophytes, or by other salts e.g. in desert regions. Similar definitions can be found in publications of ADRIANI (1958), WALTER (1961) and STOCKER (1928).

In the case of the terrestrial halophytes the salt and its activity is found in the soil environment and more precisely in the soil moisture, in which the plant-roots live. Therefore, it was of importance to analyse and study the salinity of the soil moisture of the environment of Centaurium vulgare, so that it could be confirmed that Centaurium vulgare is a halophyte. However, the above-mentioned definition for halophytes is unfit for use, if the limit between normal and higher salt levels is not known. In other words where lies the transition between saline and non-saline or fresh soil water? The answer to this question has been given in the "Final resolution of the symposium on the classification of brackish waters" (1959). In this system the limit between the oligohaline and fresh water zones is formed by a salinity of $0,05 \%$. In the present publication the author preferred to express 
the salinity as a concentration of $\mathrm{C} 1$-ions. (In the analyses of the soil moisture the actual amounts of this element were determined. Sometimes the salinity is expressed as a $\mathrm{NaCl}$-concentration which is derived from the $\mathrm{Cl}^{\prime}$ concentration. For sea water the ratio between the total amount of chlorides, $\mathrm{NaCl}$ and $\mathrm{Cl}^{\prime}$ is known, but in the soil of the Centaurio-Saginetum this ratio is possibly quite different.) So the salinity-limit must be transformed into a chlorinity-limit, as was done by BEEFTINK (1962). This leads to the conclusion that the lower limit of saline waters is formed by brackish or mixohaline water with a concentration of $0,03 \% \mathrm{Cl}^{\prime}$.

Returning to the subject of this study it may be said that Centaurium vulgare must be regarded as a halophyte, if it is possible to show the presence of a $\mathrm{Cl}^{\prime}$-concentration of $0,03 \%$ or more during a period in the life-cycle. It appeared to be possible to find such quantities of $\mathrm{Cl}^{\prime}$ in the typical environment of Centaurium vulgare. A survey of these analytical investigations will be given below. In this context it may also be said that already in a paper of earlier date some results of the investigation on the salinity of the environment of Centaurium vulgare were discribed (FREIJSEN 1964). In the same paper the results of an inundation-experiment were given. Centaurium vulgare appeared to be negatively influenced by high concentrations of $\mathrm{NaC1}$. Apparently Centaurium vulgare prefers low concentrations of $\mathrm{NaCl}$ which fact was already emphasized in the classification given by IVERSEN (1934).

Halophytes were and are divided in several ways e.g. with respect to the salt concentrations of the environment. These classifications were given by ADRIANI (1958) and ChAPMAN (1954). Very important seems to be the division into the two groups of viz. halophilous species or - when there is an absolute preference - obligate halophytes and salt-tolerant or indifferent species. As a consequence of our strictly ecological definition mainly based on the habitat also indifferent species occurring on a salt marsh may be treated as halophytes. It is obvious that Centaurium vulgare should be regarded as a true halophilous species. The distribution in the whole range, in particular on Terschelling, leads to this point of view. Because of the preference of Centaurium vulgare for low degrees of salinity the species may be described as an oligohalophilous species. In the literature little attention has been paid to these plants. Generally the so-called eu-halophytes have been described.

\subsection{The chlorinity of the soil environment}

\subsubsection{Method}

The samples which were taken for the determination of the soil moisture, were also used for the analyses of the chlorinity. For the descriptions of the sample sites the reader is referred to chapter 5 . The quantities of $\mathrm{Cl}^{\prime}$ were 
determined by titration with $\mathrm{AgNO}_{3}$ according to the method of Mohr (Strubing 1965). The chlorinity of all samples was expressed as percents Cl-ions in the soil moisture.

\subsubsection{Results of the analyses of the $\mathrm{Cl}^{\prime}$-concentration}

Table 14 shows the ranges and mean values of the $\mathrm{Cl}^{\prime}$-concentration in the soil moisture of the three slack sites. The mean values found in the $1-20 \mathrm{~cm}$ layer are about as high as the limit-concentration between brackish and fresh water: $0,03 \%$. The $\mathrm{Cl}^{\prime}$-concentration in the soil of the CentaurioSaginetum appeared to fluctuate about this value. In the vegetation period 1964 Centaurium vulgare sometimes appeared to grow under mixohaline circumstances; this confirms that this species should be regarded as a halophyte. The dry environment of site 1 had the highest salt concentrations. In the toplayer higher salt concentrations were found as a consequence of lower soil moisture values. Especially on the dry site 1 a very high maximal value was found. On the less extreme site 3 , on the other hand, the narrowest range of the chlorinity in the $0-1 \mathrm{~cm}$ layer was found.

$\begin{array}{lccc}\begin{array}{l}\text { Table 14: C1-ions concentration in percents of soil moisture of slack sites } \\ \text { site }\end{array} & \begin{array}{c}\text { range } \\ \text { mean and standard error }\end{array} & \\ 1 & 0-1 & 0,02-1,18 & 0,28 \pm 0,35 \\ & 1-20 & 0,01-0,13 & 0,04 \pm 0,03 \\ 2 & 0-1 & 0,01-0,18 & 0,07 \pm 0,05 \\ & 1-20 & 0,01-0,04 & 0,02 \pm 0,01 \\ 3 & 0-1 & 0,02-0,08 & 0,03 \pm 0,02 \\ & 1-20 & 0,01-0,04 & 0,02 \pm 0,01\end{array}$

Because the chlorinity in the present study was expressed as a concentration, its values depended on the values of the soil moisture measured. Chlorinity and soil moisture are inversely proportional. The interaction of both these environmental factors appears from Fig. 11, in which the soil moisture and $\mathrm{Cl}^{\prime}$-concentration in the $0-1 \mathrm{~cm}$ layer of site 1 are represented by curves. These curves are each other's reflected images. Similar pairs of curves might be drawn for all sites. Data on the interaction of soil moisture, influenced by weather conditions etc., and chlorinity are found in the papers of Beeftink (1965), Gillner (1960) and Chapman (1954).

The extreme values of chlorinity of about $1 \%$, which were sometimes measured, are probably unreal. BEEFTINK (1965) stated that crystallization of salts must occur in such dry soil layers before the high concentrations are attained. The occurrence of desiccation and crystallization on the surface of the Centaurio-Saginetum of slack borders is an important ecological factor. For germination Centaurium vulgare and other species must avoid periods 
Fig. 11: percentage of soil moisture, by weight, and $\mathrm{Cl}$-ions concentration in $0-1 \mathrm{~cm}$ layer of slack site 1

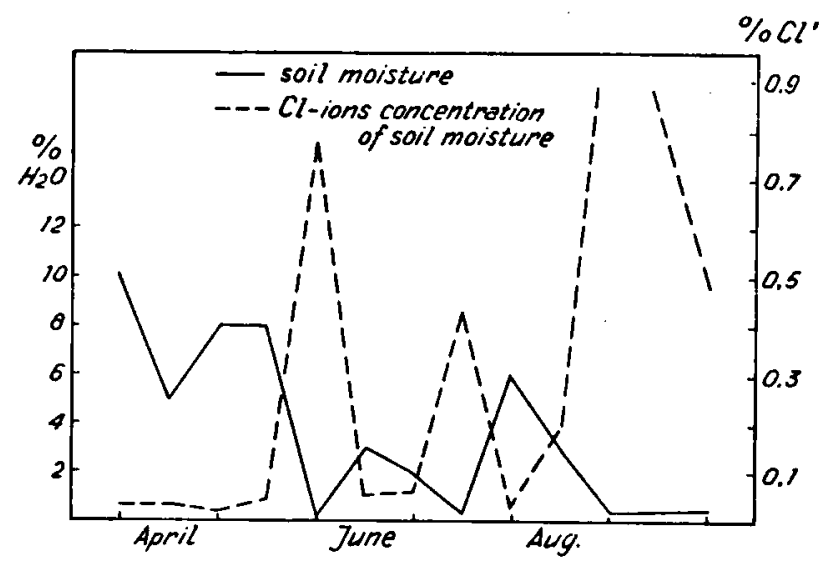

in which such unfavourable circumstances occur. Most seeds of Centaurium vulgare germinate in spring when the water content is high and the salinity low, as appears from Fig. 11. The crystallized salts on the surface play a part in the formation of a hard crust which consists of luted sand grains and dried algae.

The results of the $\mathrm{Cl}^{\prime}$-analyses in the samples of the Boschplaat-series are given in Table 15. The composition of this table corresponds to that of Table 13. On the right, ranges and mean values of chlorinity are mentioned. At first sight it seems strange that the highest $\mathrm{Cl}^{\prime}$-values of all sites on the Boschplaat were measured in the samples taken on site 1 i.e. a top of a horseshoe dune with a Koelerion-vegetation. However, it must be realized that these concentrations are a consequence of the relative dryness of this environment. Soil and vegetation of the horseshoe dunes show that the $\mathrm{Cl}^{\prime}$-concentration of the soil is not the only important environmental factor. In spite of a rather high relative salinity only a few halophytes were found in places like site 1 . The distribution of halophytes and the position of the borderline between halosere and xerosere are determined by other factors beside the salinity. Especially the water economy is very important in the determination of the distribution pattern of hygrohalophytes and mesohalophytes. For Centaurium vulgare this was discussed in previous chapters.

The results of the sandy sites 2 and 3 showed that the CentaurioSaginetum subass. saginetosum was characterized by a slightly higher salt level than the typical community. Without doubt this is caused by the close contact with sea water. As in dune slacks the extreme values were measured in the toplayer in May. Site 4 was already described as a more stable 


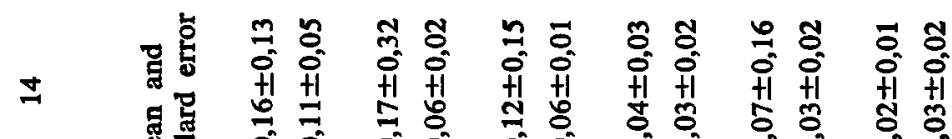

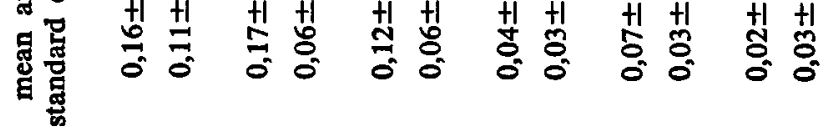

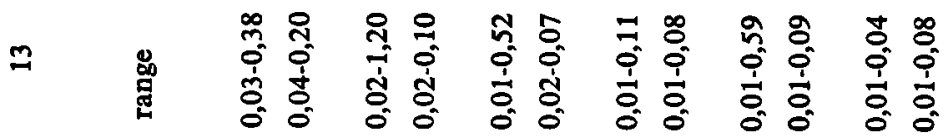

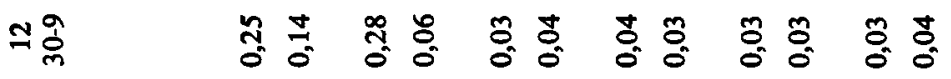

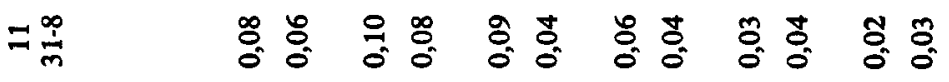

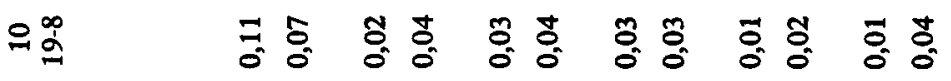

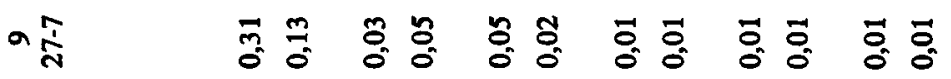

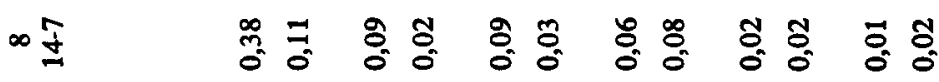

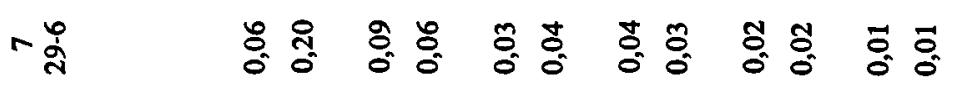

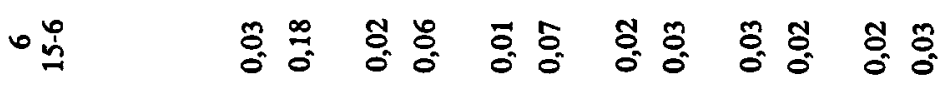
n

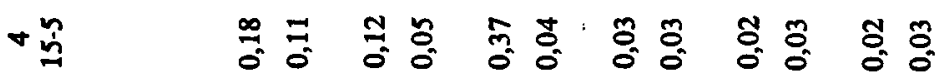
m

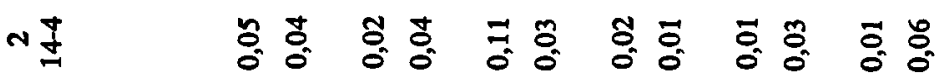
-I

\begin{tabular}{|c|c|c|c|c|c|c|}
\hline m ป & : & o: & 染 & $\begin{array}{l}\text { S: } \\
0 \\
0\end{array}$ & 횽 & $\begin{array}{l}\tilde{\delta} \\
\delta \\
0\end{array}$ \\
\hline$N I$ & 范 & s: & $\bar{z} \tilde{o}_{0}^{\circ}$ & s. & $\overline{0}:$ & \\
\hline- \pm & ${ }_{0}^{0} 0_{0}^{ \pm}$ & $\delta_{0}^{\circ}:$ & to & 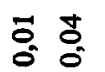 & 횽 & 0 \\
\hline
\end{tabular}
蓄 녕․․ 栆 음 
environment with regard to the water economy. The vegetation was more mesophytic and as such it could be regarded as terminal for the pioneer Centaurium vulgare. The salinity is in agreement with this. The $1-20 \mathrm{~cm}$ layer was less saline and the superficial layer showed lower values than on any other site studied. In the soil of site 5 i.e. the so-called wet saline variant of the Centaurium-community also rather low concentrations of $\mathrm{Cl}^{\prime}$ were found. Circumstances more or less reverse to those in the Koelerion of the tops of the horseshoe dunes were found. As a consequence of the generally high degree of wetness of the soil lower $\mathrm{Cl}^{\prime}$-concentrations were found, but the amount of $\mathrm{Cl}$-ions in the dry soil was higher. The high soil moisture combined with this $\mathrm{Cl}^{\prime}$-level favours the occurrence of halophytes, for instance the differential species of this variant. The fluctuations of the salt level were not more frequent or wider than in the other communities of Centaurium vulgare. Only on $28 / 5$ an extreme value was measured. It appears that there exists a difference between the saline variant of the Centaurium-community and the community of Sagina maritima in its typical form. The latter community was characterized as a sometimes very saline environment, the salt level of which may strongly vary (WESTHOFF et al. 1961 and BeEfTink 1965). Finally, Table 15 shows that the wet transition vegetation of site 6 has a stable, low salt concentration, especially in the topsoil.

\subsubsection{The halophyte Centaurium vulgare}

The supposition on the halophilous nature of Centaurium vulgare - formulated in the introduction - was confirmed by the results of the investigation of the two series of sites on Terschelling. Moreover, DE BRUYN and Borrias (1964) studied the Centaurio-Saginetum in the dune slacks of the Noordvaarder and in the area "km marks 6-8". These authors too carried out a number of analyses of soil moisture and chlorinity and found comparable values. The conclusion may be drawn that Centaurium vulgare is a halophyte occurring on slightly saline soils. Except the high values of the superficial layer all $\mathrm{Cl}^{\prime}$-concentrations were between $0,30 \%$ and $0,03 \%$, or still lower. That means that Centaurium vulgare should be classed as an oligo-halophyte, at least in the region investigated.

For a long time already the distribution and adaptations of halophytes have been important and interesting objects in ecological research. Main facts about the physiology were described by several authors. Compilations were given by ADRIANI (1958) and WALTER (1961). One of the most important features of halophytes seems to be the occurrence of high osmotic pressures in the cell sap, mainly built up by chlorides. However, only eu-halophytes seem to be treated in such eco-physiological investigations. No data are available on possible adaptations of the oligo-halophyte Cen- 
taurium vulgare. Centaurium vulgare is typified by a certain degree of succulence like many other halophytes. This feature is lacking in plants of the variety latifolium. Some incidental determinations of the chlorinity of the environment of Centaurium latifolium showed that higher concentrations of $\mathrm{Cl}^{\prime}$ occurred here, especially on the Groene Strand, which is inundated by storm-floods. In the humous toplayer a concentration of $0,18 \% \mathrm{Cl}^{\prime}$ together with a water content of $100 \%$ were found on July 30th 1964 .

\subsection{Centaurium vulgare and other saline soils}

In the atlantic part of its range Centaurium vulgare is restricted to saline soils, the salt in which was supplied by the sea. Here $\mathrm{NaCl}$ is the main salt. This is the reason, why much attention was given to the analysis of this factor in the Centaurium-biotope on Terschelling. In Mid- and Eastern-Europe Centaurium vulgare, the subspecies vulgare and uliginosum, occur on saline soils of different nature according to the records in the literature. Beside $\mathrm{NaCl}$ other salts may play a part. In this context some old papers on the occurrence of Centaurium vulgare in Mid-Germany may be mentioned. Earlier Centaurium vulgare was observed near Frankenhausen on the slope of the mountain Kyffhäuser. Several papers (LUTZE 1933, ScHULTZ 1913 and 1918, KolKwITZ 1917 and 1919) mentioned that Centaurium vulgare was found on a soil consisting of gypsum $\left(\mathrm{CaSO}_{4}\right)$ and dolomite $\left(\mathrm{CaMgCO}_{3}\right)$ without $\mathrm{NaCl}$ in a demonstrable quantity. The surprising occurrence of the halophyte Centaurium vulgare was discussed, as the possible result of the influence of gypsum. In a controversy Schulz denied the influence of gypsum, while Kolkwitz attached some value to it. It is worth mentioning that near the foot of the Kyffhäuser a salt vegetation occurred, however, without Centaurium vulgare (Altehage and Rossmann 1939). Once Centaurium vulgare was found near Maastricht (JONKER 1950). It is possible that similar conditions prevailed in this locality as those on the Kyffhäuser. The situation of Maastricht in the chalk district of the Netherlands may be an argument for this supposition. 


\section{Chapter 7:}

\section{SOIL PROPERTIES OF THE CENTAURIETO-SAGINETUM}

\subsection{Methods}

In homogeneous habitats soil samples were taken in the same way as those for the determination of soil moisture and salinity. These samples were analysed at a soil research laboratory (Bedrijfslaboratorium voor Grond- en Gewasonderzoek, Oosterbeek). The techniques of the analyses were described by De Vries and Dechering (1960). The results of the soil analyses were put together in a number of tables which are discussed below. The following soil factors are mentioned:

$\mathrm{CaCO}_{3}$ and organic matter expressed as percents, by weight, of dry soil (stove dried at $105^{\circ} \mathrm{C}$.

$\mathrm{P}$-AL = amount of available phosphate expressed as mgr $\mathrm{P}_{2} \mathrm{O}_{5}$ per $100 \mathrm{gr}$ dry soil; extraction with ammonia-lactate-acetic acid. This method is comparable with the extraction by means of citric acid.

P-total $=$ total amount of phosphate expressed as percents $\mathrm{P}_{2} \mathrm{O}_{5}$ in dry soil; extraction with mixture of concentrated $\mathrm{HNO}_{3}$ and $\mathrm{H}_{2} \mathrm{SO}_{4}$. P-total is a measure for the potential P-richness of the soil.

$\mathrm{K}-\mathrm{HCl}=$ amount of exchangeable potassium ions expressed as mgr $\mathrm{K}_{2} \mathrm{O}$ per $100 \mathrm{gr}$ dry soil; extraction with $0,1 \mathrm{~N} \mathrm{HCl}$.

$\mathrm{K}$-total $=$ total amount of potassium in the dry soil expressed as percents $\mathrm{K}_{2} \mathrm{O}$; extraction with boiling $5 \% \mathrm{HCl}$. This factor is a measure for the capacity of the soil regarding potassium.

$\mathrm{MgO}=$ amount of exchangeable magnesium ions expressed as mgr $\mathrm{MgO}$ per 1000 gr dry soil; extraction with $0,5 \mathrm{~N} \mathrm{NaCl}$-solution.

\subsection{Mechanical composition, adsorption complex and nitrogen}

Table 16 gives the mechanical composition of a soil sample taken in a dune slack near $\mathrm{km}$ mark 20. The sample, representing the layer from 6 to $20 \mathrm{~cm}$, consisted of coarse sand grains. Only very small amounts of fine sand, silt and perhaps clay were present. Other samples taken in the same or in a superficial soil layer in communities of Centaurium vulgare had the same composition. Exceptions are mentioned in the soil tables. The coarse texture of the dune soil is of crucial importance for all other soil properties. The water-holding capacity is only low. Pure sandy soils can only hold low amounts of nutrients and these are easily leached out. Because the mechanical 
Table 16: the mechanical composition of the soil near $\mathrm{km}$ mark 20

$\begin{array}{cc}\text { fraction in } \mu & \% \\ 420-300 & 0,4 \\ 300-210 & 20 \\ 210-150 & 61 \\ 150-105 & 18 \\ 105-75 & 0,2 \\ 75-50 & 0,2 \\ 50-16 & 0,1 \\ <16 & 0,2\end{array}$

composition as a whole is the same for the community of Centaurium vulgare as for many other dune environments, a further discussion of this soil factor is not given.

In twelve samples taken in soils of the Centaurio-Saginetum or adjacent plant communities on Terschelling, Vlieland and Schiermonnikoog the cation exchange capacity, the actual amount of exchangeable bases and the percentage base saturation were determined. The results varied considerably. In view of the dissimilarity and the low number of these results it was not possible to draw conclusions. The values for the cation exchange capacity ranged from 11,2 to 0,1 milliequivalents per $100 \mathrm{gr}$ dry soil with an average value of $4,0 \mathrm{mE}$. The percentage base saturation varied between 0 and $100 \%$. In general the adsorption complex of sandy dune soils is of an extremely low value, because of an almost complete absence of soil colloids: clay and humus.

In the soil samples the amounts of nitrogen were also determined. Because of the long period between sampling and analysis the results of these determinations were not reliable and they are not mentioned here. In general, soils of young dunes are very poor in nitrogen and the Centaurio-Saginetum forms no exception in this respect.

\subsection{Algae and crust formation}

Algae were observed in primary and secondary environments of Centaurium vulgare and they sometimes covered a great part of the soil surface. They can apparently establish themselves rapidly on young dune soils, as appeared from a broken-up field plot on the Boschplaat. They must be regarded as the first pioneers. Only when the surface is more or less fixed by algae forming a "net" between the sand grains, Centaurium vulgare and other phanerogams can establish themselves. It is possible that algae enrich the poor young dune soil by fixing free nitrogen from the air. Died-off algae certainly improve the physical and chemical properties of the soil. Six samples of surface algae were collected in the Centaurio-Saginetum on the Boschplaat and elsewhere on Terschelling. The algae were identified by Dr. J. Th. Koster at Leyden. The algae found were: 
Nostoc microscopicum Carm. ex Born. et Flah. in all samples, Microcoleus vaginatus (Vauch.) Gom.,

Anabaena sp.,

Palmogloea protuberans (Sm. et Sow.) Kütz and others.

In summer the $1 \mathrm{~cm}$ toplayer of the soil may become strongly desiccated. Algae dry up and salts crystallize. Dry algae and crystallized salts lute the sand grains and a surface crust is formed. In the pioneer community of Centaurium vulgare the crust should be regarded as an important protection against erosion by wind and water. It is also important in the water economy, as it stabilizes the superficial soil material. Loose sand tends to dry out to a higher degree. The evaporation is higher and the supply of water from the underground is less, because the capillaries are destroyed. Surface crusts are not typical for the Centaurio-Saginetum, but may also be found in other dune plant communities, for instance in those belonging to the Koelerion. Van Der Maarel and Van Der MaArel-Versluys (1963) reported this phenomenon for a Tortuleto-Phleetum in Great-Britain. ZuUR (1948) observed crust formation on agricultural marine sands of a reclaimed polder in the "IJselmeer". In papers on the related plant community of Sagina maritima (BeEFTINK 1965 and TüXen and Westhoff 1963) crust formation was described and connected with soil hardpans. There is, however, a difference between the typical communities of Centaurium vulgare and Sagina maritima. The soil surface in the Sagino-Cochlearietum is always covered with a silty layer, which exerts a very great influence in these processes. In a less degree the silt plays a part in the wet, saline variant of the Centaurio-Saginetum. The surface crust causes a marked and rapid transition between the soil and the atmosphere. According to VAN LEEUWEN (1965) this may be regarded as a feature of so-called convergent environments.

\subsection{Discussion of the tables with soil properties}

In Table 17 the results of the analysis of six samples taken in young dune slacks along the north coast of Terschelling are put together. All samplesites were covered with a typical vegetation of the Centaurio-Saginetum. So, the values given in this table, may be regarded to be true for the soil environment of this plant community on the island of Terschelling. The sequence of the columns in Table 17 corresponds to the position of the sample sites from west to east.

There is a great deal of similarity between the values in the separate columns. The levels of the distinct soil properties lead to the following remarks on the soil environment of Centaurium vulgare in particular or on dune soils in general. 
Table 17: soil properties of the Centaurio-Saginetum in dune slacks on Terschelling

\begin{tabular}{|c|c|c|c|c|c|c|}
\hline $\begin{array}{l}\text { Locality } \\
\text { Layer in } \mathrm{cm}\end{array}$ & $\begin{array}{l}\text { Noordv. } \\
0-15\end{array}$ & $\operatorname{km~}_{0.15} 6$ & $\mathrm{~km}_{6-25} 18-1$ & $\mathrm{~km}_{3-25} 18-2$ & $\begin{array}{l}\mathrm{km} 19 \\
0-20\end{array}$ & $\operatorname{km}_{6-25} 20$ \\
\hline $\mathrm{pH}-\mathrm{KCl}$ & 6,5 & 7,2 & 7,8 & 8,0 & 6,7 & 8,4 \\
\hline $\mathrm{CaCO}_{3} \%$ & 0,1 & 0,2 & 0,5 & 0,6 & 0,5 & 0,8 \\
\hline organic matter-\% & 0,5 & 0,3 & 0,3 & 0,3 & 0,2 & 0,2 \\
\hline P-AL & 4 & 6 & & & & 3 \\
\hline P-total-\% & 0,010 & 0,020 & 0,010 & 0,010 & 0,010 & 0,028 \\
\hline $\mathbf{K}-\mathbf{H C l}$ & 5 & 3 & 3 & 4 & 3 & 6 \\
\hline K-total-\% & 0,021 & 0,021 & 0,015 & 0,014 & 0,026 & 0,069 \\
\hline MgO & 27 & 12 & 11 & 11 & 13 & 一 \\
\hline Date & Aug. '63 & July '63 & Dec. '62 & Dec. '62 & Dec. '63 & Nov. '61 \\
\hline
\end{tabular}

The soil of the Centaurio-Saginetum is typified by a rather high $\mathrm{pH}$ which ranges from slightly acid to alkaline. This feature is correlated with the presence of free calciumcarbonate. The amount of calciumcarbonate was low in all samples investigated, increasing from west to east on the island. The Noordvaarder-dunes built up by the sand flat of the same name are extremely poor in chalk (see section 1.1). The dune slack near $\mathrm{km}$ mark 20 - at the edge of the somewhat richer Boschplaat — had the highest content. Intermediate values were found on the other sites, where the sand was supplied from the beach along the north side of the island.

On Terschelling and elsewhere - as appears from the literature Centaurium vulgare only occurs on alkaline, somewhat calcareous soils. In view of this preference Centaurium vulgare should be regarded as being oligo-calcicolous. Probably the adsorbed Ca-ions in the soil directly affect the occurrence or growth of Centaurium vulgare. JefFeries and Willis (1964) described this phenomenon for some plants.

The important influence of organic matter on physical and chemical properties of dune soils was already mentioned above and it will be treated below.

The factors P-AL and $\mathrm{K}-\mathrm{HCl}$ are parameters for the intensity of nutrients in the soil of the Centaurio-Saginetum. The values of these two soil factors give an idea about the quantities of phosphorus and potassium available for plants. These values are low in comparison with those in many other natural environments and very low compared with the nutrient levels of farm-land. The soil environment of Centaurium vulgare should be regarded as very poor in nutrients. In this respect it resembles all other environments in the outer dunes. Similar low nutrient levels were found in the dunes of Voorne (investigations at the Biological Station "Weevers' Duin") and elsewhere: Ranwell (1959) - Anglesey, Adriani (1960) - Schouwen, Westhofp (1947 a) - Terschelling. Like many other plants occurring in young dune environments Centaurium vulgare must be adapted to poor soils, at least if our and other analyses of soil factors give a true picture of the soil circum- 
stances. Nevertheless, many of these plants show positive reactions to the addition of mineral nutrients. In a tentative experiment Centaurium vulgare produced a much higher biomass on a field plot on which fertilizers were applied. Also under natural circumstances the size of the plants of Centaurium vulgare appears to be definitely influenced by the quantity of nutrients in the soil. Poorness of the soil in many habitats is a restricting factor in the development of the individual plants. From the important investigations of WILLIS and coll. (1959, 1961, 1963, 1964 and 1965) the main conclusion is that low nutrient levels cause plant communities of yellow dunes and grey dunes to be characterized by openness and the occurrence of small plants. With increasing structure and humus-content of the dune soil the nutrient contents become more favourable for plant-life. From extensive soil investigations on the island of Voorne (at the Biological Station) an increase of $\mathbf{N}$, $\mathbf{K}$ and $\mathbf{P}$ in the older dune soils became clear. This agrees with the results of GoR'HAM (1958) who worked in an English dune area. The plant roots draw minerals from the subsoil. Every autumn these elements return to the topsoil as components of organic compounds. The result of these cyclic processes is an accumulation of nutritional materials in the topsoil, which retains valuable constituents as a result of the adsorptive capacity of the accumulated organic material.

In most investigations the factors $\mathrm{P}$-total and $\mathrm{K}$-total are not determined. They are not immediately important for plant-life, but they act as parameters for the potential richness of the soil. So they may be used in the comparison of different soil types and their development. Values found in farm-land soils and in other artificial environments are higher than those of the Centaurio-Saginetum (DE VRIES and Dechering 1960). In the soil of the small dune slack near $\mathrm{km}$ mark 20 significantly higher contents of $P$ and $\mathrm{K}$ were found than on the other sample sites.

The content of exchangeable $\mathrm{Mg}$ on the sites investigated was also very low. This low content is probably not a restrictive factor. In the literature the $\mathrm{Mg}$-content of natural soils is often described as being sufficient for the vegetations present.

Table 18 shows the results of the detailed investigation of belt transect 1 (see chapter 4). Two soil layers of the higher plot A and the lower plot D were sampled. The second column of Table 18 is the same as the third column in Table 17.

The values of the soil factors are similar to those in Table 17. An exception is formed by the values given in column 3 . In the top $3 \mathrm{~cm}$ of plot $\mathrm{D}$ the sand fraction of $16-50 \mu$ amounted to $5 \%$. Normally the percentage of fine sand in dune soils is only very low. Also the content of organic matter was somewhat higher. Together with these slightly higher amounts of organic matter and fine soil particles higher values for the following factors were found: 
Table 19: soil properties of the Centaurio-Saginetum subass. of Sagina maritima on horseshoe dunes of Boschplaat

\begin{tabular}{|c|c|c|c|c|c|c|c|c|c|c|}
\hline Variant & \multicolumn{6}{|c|}{ dry } & \multicolumn{4}{|c|}{ wet, saline } \\
\hline Site & & $22-1$ & $\mathbf{k m}$ & $22-2$ & km & 23 & $\mathbf{k m}$ & $22-2$ & $\mathbf{k m}$ & 23 \\
\hline Layer in $\mathrm{cm}$ & $0-6$ & $6-25$ & $0-1$ & $1-20$ & $0-1$ & $1-20$ & $0-1$ & $1-20$ & $0-1$ & $1-20$ \\
\hline fraction $<16 \mu-\%$ & 0,3 & 0,2 & - & - & - & - & 6 & 一 & 6 & - \\
\hline $\mathrm{pH}-\mathrm{KCl}$ & 6,7 & 7,7 & 6,5 & 6,9 & 6,5 & 6,8 & 6,4 & 6,5 & 6,9 & 6,7 \\
\hline $\mathrm{CaCO}_{3}-\%$ & 0,2 & 0,8 & 0,1 & 0,5 & 0,2 & 0,3 & 0,1 & 0,6 & 0,9 & 0,4 \\
\hline organic matter-\% & 1,0 & 0,3 & 1,3 & 0,2 & 1,4 & 0,4 & 3,0 & 0,5 & 3,8 & 0,4 \\
\hline P-AL & 6 & 5 & 5 & 4 & 5 & & 7 & 4 & 10 & 4 \\
\hline P-total-\% & 0,02 & 0,018 & 0,020 & 0,020 & 0,020 & 0,020 & 0,040 & 0,020 & 0,060 & 0,020 \\
\hline K-HCl & 9 & 7 & 13 & 6 & 12 & & 26 & 7 & 42 & 5 \\
\hline K-total-\% & 0,03 & 0,030 & 0,041 & 0,029 & 0,039 & 0,026 & 0,075 & 0,030 & 0,117 & 0,029 \\
\hline $\mathrm{MgO}$ & - & - & 150 & 80 & 159 & 55 & 394 & 83 & 587 & 80 \\
\hline
\end{tabular}

all sites sampled in December 1963, except no. 1 in November 1961 
Table 18: soil properties of transect 1

Sample plots
Layer in cm
fraction $16-50 \mu-\%$
pH-KCl
$\mathrm{CaCO}_{3}-\%$
organic matter-\%
P-AL
P-total-\%
K-HCl
K-total-\%
MgO

Sample plots
A

$6-25$
0,1
7,8
0,5
0,3
4
0,010
3
0,015
11

\section{$0-3$}

5
7,5
0,6
1,2
4
0,017
6
0,018
34

D

0,1

7,9

0,3

0,3

3

0,010

4

0,012

12

date of sampling December 1962

P-total, K-HCl, K-total and $\mathrm{MgO}$. Fine soil particles are supplied by the water assembling in the slack during wet periods. Minerals are washed out of the soils of the slopes and they are retained by the toplayer of the slack bottom. This process is the beginning of the differentiation of slack and dune-top soils. Data of soil investigations on Voorne point in the same direction and RaNwELL (1959) described this phenomenon for Newborough Warren (Great-Britain). Although it may be concluded that the soil of sample plot $D$ was more favourable for plant growth with respect to the presence of nutrients, it was clear that the environment as a whole was not favourable for Centaurium vulgare. As was described above, only very small plants with a reduced vitality occurred on this sample plot. Centaurium vulgare cannot attain a normal vitality on this low level because the water factor becomes maximal and restrictive. An increase in nutrient content of such habitats does not influence the behaviour of the plant.

Table 19 gives soil properties of the Centaurio-Saginetum subass. of Sagina maritima. Samples were taken on horseshoe dunes. The three left columns refer to the dry variant and the last two columns to the wet saline variant. By comparing Tables 19 and 17 differences between the typical and the saline subassociation of the Centaurium-community may be seen. In the subsurface layer the $\mathrm{pH}$ is generally somewhat lower, but $\mathrm{K}$-total and $\mathrm{MgO}$ are rather high, which is the result of periodical inundations by the sea. The properties of the $1 \mathrm{~cm}$ toplayer show that a slight increase (1\%) in organic matter markedly influences the contents of nutrients. In the wet saline variant silt and clay are sedimented by the high-tide water. The $6 \%$ fine soil particles and 3-4\% organic matter in its superficial soil layer cause higher amounts of minerals to be hold. In spite of this higher fertility of the silty layer only small specimens of Centaurium vulgare are found in the wet saline variant of the community. 
Table 19a: soil properties of surrounding communities on the Boschplaat

\begin{tabular}{|c|c|c|c|c|c|c|}
\hline \multirow{2}{*}{$\begin{array}{l}\text { Community } \\
\text { Site } \\
\text { Layer in cm }\end{array}$} & \multicolumn{4}{|c|}{ Juncetum gerardii } & \multicolumn{2}{|c|}{$\begin{array}{l}\text { Koelerion } \\
\text { km 22,5 }\end{array}$} \\
\hline & $0-5$ & $5-25$ & $0-5$ & $5-25$ & $0-5$ & $5-25$ \\
\hline fraction $<16 \mu-\%$ & 3 & 1 & 3,5 & - & - & - \\
\hline pH-KCl & 7,5 & 8,3 & 6,9 & 7,9 & 7,9 & 7,3 \\
\hline $\mathrm{CaCO}_{3}-\%$ & 0,4 & 0,8 & 0,3 & 0,7 & 0,6 & 0,8 \\
\hline organic matter-\% & 1,4 & 0,4 & 3,1 & 0,5 & 0,6 & 0,4 \\
\hline P-AL & 7 & 5 & 11 & 4 & 4 & 5 \\
\hline P-total-\% & 0,030 & 0,019 & 0,051 & 0,020 & 0,020 & 0,020 \\
\hline K-HCl & 13 & & 32 & 10 & & \\
\hline K-total-\% & 0,051 & 0,035 & 0,089 & 0,021 & 0,020 & 0,014 \\
\hline MgO & - & - & 556 & 100 & 44 & 21 \\
\hline
\end{tabular}

first site sampled in November 1961; other sites in December 1962

The first two double columns in Table 19a give soil properties of sites belonging to the Juncetum gerardii-community surrounding the horseshoe dunes on the Boschplaat. Just as in the saline wet Centaurium-community a superficial silty soil layer is present, its size may amount up to $5 \mathrm{~cm}$. As a consequence of this more nutrients are available and dense swards of Festuca litoralis can develop in this environment. The properties of the Koelerionenvironment on the tops of horseshoe dunes - shown in the last columns are similar to those of the Centaurium-habitat. The upper limit of the Centaurium-zone is not determined by chemical soil factors.

Table 20: soil properties of the Centaurio-Saginetum outside Terschelling

\begin{tabular}{|c|c|c|c|c|c|c|}
\hline Locality & V.1 & S.1 & S.2 & O & \multicolumn{2}{|c|}{ B } \\
\hline Layer in $\mathrm{cm}$ & $0-20$ & $0-15$ & $0-15$ & $0-25$ & $0-6$ & $6-25$ \\
\hline fraction $<16 \mu-\%$ & 0,1 & 2,5 & 1,0 & 2,5 & 2,5 & 1,5 \\
\hline pH-KCl & 7,3 & 8,4 & 8,5 & 7,3 & 7,3 & 7,9 \\
\hline $\mathrm{CaCO}_{3}-\%$ & 0,3 & 0,8 & 1,4 & 6,0 & 7,7 & 7,9 \\
\hline organic matter-\% & 0,3 & 0,2 & 0,1 & 0,3 & 1,0 & 0,4 \\
\hline P-AL & 4 & 6 & 6 & 11 & 9 & 9 \\
\hline P-total-\% & 0,024 & 0,018 & 0,019 & 0,034 & 0,057 & 0,044 \\
\hline $\mathrm{K}-\mathrm{HCl}$ & 6 & 7 & 7 & 6 & 8 & 7 \\
\hline K-total-\% & 0,030 & 0,029 & 0,026 & 0,055 & 0,084 & 0,077 \\
\hline $\mathrm{MgO}$ & 8 & - & - & - & - & 一 \\
\hline
\end{tabular}

Localities: V.1 = Vlieland, "Stuifpolder", young dune slack on W. part of the island; sampled in November 1963 - S.1 and S.2 = Schiermonnikoog, Oosterstrand, beach plain, subass. of Sagina maritima, viz. saline and dry variant; sampled in July $1962-$ $\mathrm{O}=$ Oostvoorne, dune slack - B = De Beer, Vogelplaat; sampled in September 1962.

During the investigations a few localities outside Terschelling were studied (see Table 20). The soils of the Westfrisian Islands Vlieland and Terschelling 
have much in common. Both soils are very poor in free carbonate and nutrients. It is not amazing that the soil of the Centaurium-site on Vlieland completely resembles the Terschelling-habitat described above. The island of Schiermonnikoog is more calcareous than any other part of the "WaddenDistrict". One of the sites analysed contained $1,4 \% \mathrm{CaCO}_{3}$. In the layer of $0-15 \mathrm{~cm}$ the percentage of fine soil particles was higher than in any corresponding layer on Terschelling. The quantities of carbonate and silt were still higher in the samples of Voorne and the former "De Beer", which are part of the calcareous "Dune-District". Other soil properties of these localities appeared to attain higher values than on Terschelling.

Table 21: the soil environment of Centaurium vulgare var. latifolium

$\begin{array}{lllc}\text { Locality } & \text { Gr.Strand } & \text { Groede } & \text { Midsl.a.Zee } \\ \text { Layer in cm } & 0-5 & 0-5 & 0-4 \\ & & & \\ \text { pH-KCl } & 5,4 & 5,7 & 6,6 \\ \text { CaCO3-\% } & 0 & 0 & 0,1 \\ \text { organic matter-\% } & 13,7 & 17,2 & 2,2 \\ \text { P-AL } & 10 & 8 & 6 \\ \text { P-total-\% } & 0,082 & 0,083 & 0,027 \\ \text { K-HCl } & 37 & 23 & 8 \\ \text { K-total-\% } & 0,055 & 0,046 & 0,020\end{array}$

all sites sampled in July 1964

The sites on Terschelling in which Centaurium vulgare var. latifolium was found, were investigated. The results of the analysis of the superficial humous layer are given in Table 21. Especially the soils on the Groene Strand and on the Groede diverge conspicuously from the normal soil circumstances of Centaurium vulgare var. vulgare and var. iberoides. The content of organic matter is considerable. No more free carbonates are present and the $\mathrm{pH}$ is strongly decreased. The nutrient levels, on the contrary, are higher than those in soils of the typical Centaurium-community and the saline subassociation. These divergent soil circumstances were found in the transition zone between on the one side the oligohalobious plants of the old salt marsh and on the other side the calcifuge plants occurring in higher leachedout places. This situation is best developed on the oldest salt marsh the Groene Strand, where only Centaurium vulgare var. latifolium occurs. In the same zone on the Groede also plants of Centaurium vulgare var. vulgare were found. With regard to soil properties the site in Midsland-aan-Zee is more or less the intermediate environment between those of the varieties vulgare and latifolium. In this light it is clear that both these paramorphs and also var. iberoides occur there. 


\section{Conclusions}

Concluding the soil environment of Centaurium vulgare var. vulgare and var. iberoides may be described as follows:

1. very young to young (or secondarily rejuvenated) dune soils, always containing a small amount of organic material already;

2. almost completely consisting of coarse sand; sometimes covered with a thin silty layer supplied by the sea or caused by a leaching-process; sometimes silt occurs thoughout the soil profile;

3. the $\mathrm{pH}-\mathrm{KCl}$ is slightly acid to alkaline; some free carbonate at least is present;

4. the levels of available and not exchangeable nutrients are low, as is normally found in young dune soils; the presence of small amounts of fine particles or organic matter favours the origin of a somewhat higher nutrient status. 


\section{ACKNOWLEDGEMENTS}

During the investigation and the preparation of the manuscript the author received help from persons and Institutes, mentioned below, for which he wishes to express his gratitude.

The investigation was executed under the supervision of Professor J. Lanjouw (Botanical Museum and Herbarium at Utrecht). Professor F. P. Jonker (idem) drew the author's attention to the species Centaurium vulgare. Assistance was rendered by Mr. B. Zwaagstra (on Terschelling) and Miss J. H. M. Olk (in Oostvoorne). Dr. K. U. Kramer (Utrecht) gave advice with respect to taxonomical problems. The identification of some of the mosses was verified by Mr. A. Touw (Leyden). Dr. P. Stoutjesdijk (Oostvoorne) read the manuscript and offered critical comments. Mrs. M. M. Soekarjo (Utrecht) read the English text of the manuscript. Other persons who rendered help or gave specific information are mentioned in the text.

The greater part of the investigation - from September 1961 till July 1964 on Terschelling - was made possible by a full grant of the Netherlands Organization for the Advancement of Pure Research (Z.W.O. The Hague) and was executed within the framework of the research programme of the Foundation of Dune Research (S.W.D.). Furthermore, this Foundation made it possible, by a grant, to obtain the help of an assistant. After this period the author joined the Institute for Ecological Research (I.O.O. at Arnhem). The Director Dr. H. N. Kluyver and the Head of the Botanical Department Dr. M. J. Adriani (Oostvoorne) allowed the author ample freedom to complete this investigation.

On Terschelling the author made use of the accommodation of the Biological Field Station. For this and other reasons the author is greatly indebted to the State Institute for Nature Conservation Research (R.I.V.O.N. at Zeist) and in particular to its Director Professor M. F. Mörzer Bruyns. 


\section{REFERENCES}

Adriant, M. J. 1958. Halophyten. In: W. RuHland. Handbuch der Pflanzenphysiologie. 4: 709. Berlin etc.

- 1960. Enkele gegevens over de botanische oecologie van de "Kop van Schouwen". Chapter 3 of RIVON report.

Altehage, C. and B. Rossmann. 1939. Vegetationskundliche Untersuchungen der Halophytenflora binnenländischer Salzstellen im Trockengebiet Mitteldeutschlands. Beih. Bot. Centralbl. B, 60: 135.

BAKKER, D. 1966. On life forms of hapaxanths in the Dutch flora. In: D. BAKKER, Sina J. TER Borg and D. OTZzN. Ecological Research at the Plantecology Laboratory, State University, Groningen. Wentia 15: 13.

BeEFTINK, W. G. 1959. Some notes on Skallingens salt marsh vegetation and its habitat. Acta Bot. Neerl. 8: 449.

- 1962. Conspectus of the phanerogamic salt plant communities in the Netherlands. Biol. Jaarb. Dodonaea 30: 325.

- 1964. Rapport inzake de 8e excursie van de Internationale Vereniging voor Vegetatiekunde, gehouden van 28 mei tot 8 juni 1962 in het kustgebied van NW- en W-Frankrijk. Report Hydrobiol. Inst. Yerseke.

-. 1965. De zoutvegetatie van ZW-Nederland beschouwd in Europees verband. Diss. Wageningen.

Bleasdale, J. K. A. 1960. Studies on plant competition. In: J. L. Harper. The biology of weeds. Symposium Brit. Ec. Soc. 1: 133. Oxford.

BoERBOOM, J. H. A. 1958. Inventarisatie van de hogere planten van het Haagse duingebied. De Levende Natuur 61: 17.

- 1960. De huidige begroeiing in en rond de duinmeren bij Den Haag. De Levende Natuur 63: 31.

Bonnier, G. 1912-1934. Flore complète illustrée en couleurs de France, Suisse et Belgique. 7 Neuchâtel etc.

Braun-Blanquet, J. 1932. Plant Sociology. New York.

- 1951. Pflanzensoziologie. 2e Aufl. Wien.

-. 1964. Pflanzensoziologie. 3e Aufl. Wien and New York.

- and J. C. DE LeEUw. 1936. Vegetationsskizze von Ameland. Ned. Kruidk. Arch. 46: 359.

-, N. Roussine and R. Nègre. 1952. Les Groupements végétaux de la France méditerranéenne. Centre Nat. Rech. Scient. Montpellier.

Brink, B. A. 1964. Mikrosystematiek van Centaurium littorale (Turner) Gilm. speciaal op Terschelling. Report Bot. Mus. and Herb. Utrecht.

BruYN, P. J. DE and W. E. Borrias. 1964. Enige gegevens over de oecologie van Centaurium littorale op het westelijk deel van het eiland Terschelling. Report Bot. Mus. and Herb. Utrecht.

Buchenau, F. von. 1896. Flora der Ostfriesischen Inseln. Leipzig.

Cain, S. A. and G. M. De Oliveira Castro. 1959. Manual of vegetation analysis. New York.

Chapman, V. J. 1954. The influence of salts upon the terrestrial halophytes. Rapports parvenus avant le 8e Congrès Int. Bot. 7-8: 194. Paris.

Christiansen, W. 1953. Neue kritische Flora von Schleswig-Holstein. Rendsburg.

Clapham, A. R., T. G. TUtin and E. F. Warburg. 1962. Flora of the British Isles. 2nd ed. Cambridge. 
Diemont, W. H., G. Sissingh and V. Westhofr. 1940. Het Dwergbiezenverbond (Nanocyperion flavescentis) in Nederland. Ned. Kruidk. Arch. 50: 215.

DiEREN, J. W. vaN. 1934. Organogene Dünenbildung. 's-Gravenhage.

DoING, H. 1962. Systematische Ordnung und floristische Zusammensetzung niederländischer Wald- und Gebüschgesellschaften. Diss. Wageningen. Wentia 8: 1.

- 1963. Uebersicht der floristischen Zusammensetzung, der Struktur und der dynamischen Beziehungen Niederländischer Wald- und Gebüschgesellschaften. Med. Landb. Hogeschool Wageningen 63/2: 1 .

Duvigneaud, P. 1947. Remarques sur la végétation des pannes dans les dunes littorales entre la Panne et Dunkerque. Bull. Soc. Roy. Belg. 79: 123.

Elliston Wright, F. R. 1951-1953. Note on the dispersal of Sagina nodosa var. moniliformis Lange. Watsonia 2: 369.

ENGELHARDT, J. H. 1928. Bijdrage tot de kennis van capillaire verschijnselen in verband met de heterogeniteit van den grond. Groningen and Den Haag.

Final resolution of the symposium on the classification of brackish waters. 1959. Arch. Océan. Limnol. 11 (suppl.): 243.

Fournier, P. 1961. Les quatre flores de la France. nouv. tir. Paris.

- 1947. Le livre des plantes médicinales et vénéneuses de France. 1. Encycl. Biol. 25. Paris.

Fouw, J. E. L. DE. 1962-1963. Een onderzoek naar de verspreiding en patroonvorming van een aantal plantensoorten op de duintjes van de Boschplaat van Terschelling. Report Bot. Mus. and Herb. Utrecht.

Freusen, A. H. J. 1964. Remarks on the halophyte Centaurium littorale. Proc. Kon. Ned. Akad. Wet. C 67: 208.

-. 1967. Some observations on the transition zone between the xerosere and the halosere on the Boschplaat, with special attention to Centaurium vulgare. Acta Bot. Neerl. 15: 668.

- and H. T. A. van Heusden. 1965. Festuca rubra L. op Terschelling. Gorteria 2: 149.

GillNER, V. 1960. Vegetations- und Standortsuntersuchungen in den Strandwiesen der Schwedischen Westküste. Acta Phytogeogr. Suec. 43: 1.

GiLmour, J. S. L. 1937. Notes on the genus Centaurium. 1. The nomenclature of the British species. Bull. Misc. Inf. (Kew Bull.): 497.

Goethart, J. W. C., P. Tesch, E. Hesselink and M. D. Dist. 1924. Cultuur- en waterleidingbelangen. Uittreksel uit het rapport over den invloed van wateronttrekking door waterleidingen op de vegetatie. Med. Rijksboschbouwproefstation. 1/3: 5 .

GroEnEwOUD, C. 1962. Algemene opzet en werkwijze van het Archief van Grondwaterstanden T.N.O. Med. 2. 's-Gravenhage.

Gorham, E. 1958. Soluble salts in dune sands from Blakeney Point in Norfolk. J. Ecol. 46: 373.

HARPER, J. L. 1960. Factors controlling plant numbers. In: J. L. HARPER. The biology of weeds. Symposium Brit. Ec. Soc. 1: 119. Oxford.

- 1961. Approaches to the study of plant competition. In: F. L. MiLthorpe. Mechanisms in biological competition. Symposium Soc. Exp. Biol. 15: 1. Cambridge.

- and R. A. Benton. 1966. The behaviour of seeds in soil. II The germination of seeds on the surface of a water supplying substrate. J. Ecol. 54: 151.

-, J. T. Williams and G. R. SAGar. 1965. The behaviour of seeds in soil. I The heterogeneity of soil surface and its role in determining the establishment of plants from seed. J. Ecol. 53: 273. 
Hegr, G. 1927. Illustrierte Flora von Mittel-Europa. 5/3. München.

HeuKels, H. and S. J. vAN OOSTSTROOM. 1962. Flora van Nederland. 15e dr. Groningen. Hermann, F. 1956. Flora von Nord- und Mitteleuropa. Stuttgart.

Hillmann, J. and V. GrummanN. 1957. Flechten. Kryptogamenflora der Mark Brandenburg und angrenzender Gebiete. 8. Berlin.

HoEve, J. TER. 1951. Een vergelijking tussen weersgesteldheid en grondwaterstand in de duingebieden van Vlieland en Terschelling. Landb. Tijdschr. 63: 715.

Hoogenrand, H. R. 1951. Biografie. In: G. J. A. Mulder. Handboek der geografie van Nederland. 2: 1. Zwolle.

Horticultural Colour Chart I and II. 1939 and 1941. Brit. Council and Roy. Hort. Soc.

HULTEN, E. 1950. Atlas of the distribution of vascular plants in N.W. Europe. Stockholm.

Hylander, N. 1945. Nomenklatorische und systematische Studien uber nordische Gefässpflanzen. Uppsala Universitets Arsskrift 7: 258.

IVERSEN, J. 1936. Biologische Pflanzentypen als Hilfsmittel in der Vegetationsforschung. Medd. Skalling-Lab. 4. Kopenhagen.

JanChen, E. 1958. Catalogus Florae Austriae. 3. Wien.

Jansen, P. 1951. Gramineae. In: Th. Weevers et al. Flora Neerlandica 1,2. Kon. Ned. Bot. Ver. Amsterdam.

JefFeries, R. L. and A. J. Willis. 1964. Studies on the calcicole-calcifuge habit. I Methods of analysis of soil and plant tissues and some results of investigations on four species. J. Ecol. 52: 121.

II The influence of calcium on the growth and establishment of four species in soil and sand cultures. J. Ecol. 52: 691.

JoNKer, F. P. 1950. Revisie van de Nederlandse Gentianaceae. I Centaurium Hill. Ned. Kruidk. Arch. 57: 169.

KoLkwIrz, R. 1917. Ueber die Standorte der Salzpflanzen. Ber. deutschen Bot. Ges. 35: 518.

-. 1919. Ueber die Standorte der Salzpflanzen. IV Erythraea linariifolia. Ber. deutschen Bot. Ges. 37: 420.

Lambinon, J. 1956. Aperçu sur les groupements végétaux du district maritime Belge entre la Panne et Coxyde. Bull. Soc. Roy. Bot. Belg. 88: 107.

LATENSTEIN VAN VoORST, D. 1958. Natura 55: 140.

LEEUWEN, C. G. VAN. 1965. Het verband tussen natuurlijke en anthropogene landschapsvormen, bezien vanuit de betrekkingen in grensmilieus. Gorteria 2: 93.

- 1966. A relation theoretical approach to pattern and process in vegetation. Wentia 15: 25.

LODGE, R. W. 1964. Autecology of Cynosurus cristatus L. III Germinability and seedling establishment. J. Ecol. 52: 43.

LUTzE, G. 1913. Die Salzflorenstätten in Nordthüringen. Mitt. Thür. Bot. Ver. N.F. 30: 1.

Lyon, T. L., H. O. Buckman and N. C. Brady. 1956. The nature and properties of soils. New York.

MAAREL, E. VAN DER and G. LONDO. 1960. De plantengroei van het Vogelmeer in de Kennemerduinen. De Levende Natuur 63: 253 and 283.

- and M. van Der MaArel-Versluys. 1963. Over Engelse duingebieden. De Levende Natuur 66: 1, 25 and 217.

- and V. Westhofp. 1964. The vegetation of the dunes near Oostvoorne (the Netherlands) with a vegetation map. Wentia 12.

-, V. WeSthofF and C. G. vAN LeEUWEN. 1964. European approaches to the variation in vegetation, considered from a system theoretical point-of-view. Lect. 10th Int. Bot. Congress, also RIVON report. 
Mansfeld, R. 1939. Zur Nomenklatur der Farn- und Blütenpflanzen Deutschlands. VI. Fedde's Repertorium 47: 37.

Marsson, T. F. 1869. Flora von Neu Vorpommern und den Inseln Rügen und Usedom. Leipzig.

MaUde, P. F. 1939. The Merton Catalogue. A list of the chromosome numerals of species of British flowering plants. New Phyt. 38: 1.

Melderis, A. 1931. Genetical and taxonomical studies in the genus Erythraea Rich. I. Acta Horti Bot. Univ. Latv. 6: 123.

Newman, E. 1. 1963. Factors controlling the germination date of winter annuals. J. Ecol. 51: 625 .

NöLDEKE, C. 1872-1873. Flora der ostfriesischen Inseln mit Einschluss von Wangeroog. Abh. Naturwiss. Ver. Bremen 3: 93.

Nordhagen, R. 1940. Norsk Flora. Oslo.

Oberdorfer, E. 1957. Süddeutsche Pflanzengesellschaften. Reihe Pflanzensoziologie 10. Jena.

O'Connor, W. M. T. 1955. Variation in Centaurium in West Lancashire. In: J. E. LousLeY. Species studies in the British flora. Report Bot. Soc. Brit. Isles: 119.

Passarge, H. 1964. Die Pflanzengesellschaften des nordostdeutschen Flachlandes I. Reihe Pflanzensoziologie 13. Jena.

Perring, F. H. and S. M. Walters. 1962. Atlas of the British Flora. London.

RANWELL, D. 1959 and 1960. Newborough Warren, Anglesey. I The dune system and dune slack habitat. J. Ecol. 47: 571. II Plant associes and succession-cycles of the sand dune and dune slack vegetation. J. Ecol. 48: 117.

RATCliffe, D. 1961. Adaptation to habitat in a group of annual plants. J. Ecol. 49: 187.

Robijns, A. 1954. Essai d'étude systématique et écologique des Centaurium de Belgique. Bull. Jard. Bot. de l'Etat, Brux. 24: 439.

Rode, A. A. 1959. Das Wasser im Boden. (German edition by M. Trénel) Berlin.

ROTHMALER, W. 1963. Exkursionsflora von Deutschland IV, kritischer Ergänzungsband Gefässpflanzen. Berlin.

SAlisbURY, E. J. 1942. The reproductive capacity of plants. London.

-. 1952. Downs and dunes. London.

SCnMONI, A. 1963. Einführung in die praktische Vegetationskunde. 2e Aufl. Jena.

Schotsman, H. D. 1956. Parnassia onderzoek op de Boschplaat. Report Bot. Mus. and Herb. Utrecht.

SChroevers, P. J. 1951. De structuur van het plantendek der Buiten-Geulvallei. Ned. Kruidk. Arch. 58: 176.

Scrulz, A. 1913. Ueber das Vorkommen von Erythraea litoralis Fr. bei Frankenhausen. Mitt. Thür. Bot. Ver. N.F. 30: 42.

-. 1918. Ueber das Vorkommen von Halophyten im Mitteldeutschland auf kochsalzfreien Boden. Ber. deutschen Bot. Ges. 36: 410.

ShishKiv, B. K. and E. G. Bobrov. 1952. In: V. L. Komarov. Flora of the U.S.S.R. 18. Bot. Inst. Ac. Sci. Moscow and Leningrad.

SpexMan, J. and J. Groten. 1963. Enkele aspecten van het Saginetum maritimae op de Beer en de Boschplaat. Report Bot. Mus. and Herb. Utrecht.

Stankov, S. S. and B. I. TAliJEv. 1957. Flora of the European part of the U.S.S.R. (translated title). Moscow.

STERnER, R. 1939. Centaurium vulgare Rafn, Centaurium Erythraea Rafn or Erythraea littoralis (Turner) Fries? Bot. Not.: 718.

-. 1940-1941. Polymorfin inom Centaurium vulgare gruppen. Medd. Göteb. Bot. Trädgård 14: 109.

Steubing, L. 1965. Pflanzenökologisches Praktikum. Berlin and Hamburg. 
Stocker, O. 1928. Das Halophytenproblem. Er. Biol. 3: 265.

TOORN, J. VAN DER. 1959. De vegetatie van gebied "paal Q" op Schiermonnikoog. Report Plantecology Laboratory Groningen.

Tüxen, R. 1955. Das System der nordwestdeutschen Pflanzengesellschaften. Mitt. Flor.soz. Arbeitsgem. N.F. 5: 155.

- and coll. 1957. Die Pflanzengesellschaften des Aussendeichslandes von Neuwerk. Mitt. Flor.-soz. Arbeitsgem. N.F. 6-7: 205.

- and V. WesthoFf. 1963. Saginetea maritimae, eine Gesellschaftsgruppe im wechselhalinen Grenzbereich der europäischen Meeresküsten. Mitt. Flor.-soz. Arbeitsgem. N.F. 10: 116.

Veinmeyer, F. J. 1956. Soil moisture. In: W. Ruhland. Handbuch der Pflanzenphysiologie 3: 64. Berlin etc.

VersLUYS, J. 1916. De capillaire werkingen in den bodem. Diss. Amsterdam.

Visser, J. C. 1947. De stuifdijken op Vlieland en Terschelling. Tijdschr. Kon. Ned. Aardr. Gen., 2e Reeks 64: 31.

VRies, O. De and F. J. A. Dechering. 1960. Grondonderzoek. 4e dr. Meppel.

VuYCx, L. 1904. Prodromus Florae Batavae 1/3. Kon. Ned. Bot. Ver. Nijmegen.

Walter, H. 1960. Einführung in die Phytologie 3/1. Stuttgart etc.

- 1961. The adaptation of plants to saline soils. Arid zone Research 4, Proc. Teheran Symp., publication Unesco: 129.

Wendelberger, G. 1950. Zur soziologie der kontinentalen Halophytenvegetation Mitteleuropas. Denkschr. Oesterr. Akad. Wiss. 108/5: 1.

WeSTHOFF, V. 1947a. De vegetatie der duinen en wadgebieden van Terschelling, Vlieland en Texel. Manuscript of diss.

- 1947b. The vegetation of dunes and salt marshes of the Dutch Islands of Terschelling, Vlieland and Texel. Diss. 's-Gravenhage.

- 1963. Achteruitgang van Catapodium marinum op Goeree na de strenge winter van 1962-1963. De Levende Natuur 66: 216.

-, J. W. Dus, H. Passchier and G. Sissingh. 1946. Overzicht der plantengemeenschappen in Nederland. 2e druk. Bibl. Ned. Natuurhist. Ver. 7.

-, C. G. van LeeUWEn and M. J. Adriani. 1961. Enkele aspecten van vegetatie en bodem der duinen van Goeree, in het bijzonder de contactgordels tussen zout en zoetmilieu. Jaarb. 1961 Wet. Gen. Goeree en Overflakkee: 46.

- and M. F. Mörzer BruYns. 1956. De groeiplaats van Scirpus americanus Pers. op het Groene Strand bij West-Terschelling. Acta Bot. Neerl. 5: 344.

-, E. E. vAN DER Voo and C. G. van LeEUWEN. 1960. De flora en vegetatie van de "Kop van Schouwen". Chapter 2 of RIVON report.

WIJx, R. vAN DER. 1962. Lijst van de in Nederland voorkomende Bryophyta. Buxbaumia 16: 50.

Willis, A. J. 1963. Braunton Burrows: the effects on the vegetation of the addition of mineral nutrients to the dune soils. J. Ecol. 51: 353 .

-. 1964. The influence of mineral nutrients on the vegetation of sand-dune communities. Abstracts 10th Int. Bot. Congr.: 265.

- 1965. The influence of mineral nutrients on the growth of Ammophila arenaria. J. Ecol. 53: 735.

-, B. F. FolKes, J. F. Hope-Simpson and E. W. Yemm. 1959. Braunton Burrows: the dune system and its vegetation. Part I and II. J. Ecol. 47: 1 and 249.

- and E. W. YemM. 1961. Braunton Burrows: mineral nutrient status of the dune soils. J. Ecol. 49: 377.

WitrRock, V. B. 1884. Report in: Bot. Centralbl. 19: 58.

WuLFF, H. D. 1937. Karyologische Untersuchungen an der Halophytenflora SchleswigHolsteins. Jb. Wiss. Bot. 84: 812. 
Zeltaker, 1962. Deuxième contribution á l'étude cytologique des genres Blackstonia Huds. et Centaurium Hill. Bull. Soc. Neuch. Sci. Nat. 85: 83.

ZuUR, A. J. 1948. Stuiven bij mariene gronden. Med. bl. Landbouwvoorl. dienst 5: 518. 